\title{
CHANNELING: IDENTITY-BASED SOCIAL MOVEMENTS AND PUBLIC LAW
}

\author{
WILLIAM N. ESKRIDGE, JR. ${ }^{\dagger}$
}

Law professiors have a lot to learn from sociologists and political scientists who have studied social movements. Social movements generated many important statutes we now take for granted, such as the environmental and civil rights laws. The dynamics of statutory evolution are strongly influenced by those movements and their internal dynamics.' Social movements have been one engine driving constitutional evolution as well. The modern meaning of the Equal Protection Clause owes much more to the power and norms of the civil rights and women's liberation movements than to the original intent of the Fourteenth Amendment's framers. ${ }^{2}$ If these positive propositions are true, it behooves us to understand and teach our students more about social movement theories.

Three kinds of social movement theories are particularly pertinent to law. ${ }^{3}$ Cultural change theories concern themselves with the evolution of social norms and the dynamic interaction between new movements and old norms. ${ }^{4}$ Resource mobilization theories ask why selfinterested persons would participate in social movements and develop

${ }^{\dagger}$ Deputy Dean and John A. Garver Professor of Jurisprudence, Yale Law School. I am grateful to Michael Shomsky, Yale Law Class of 2003, for excellent research assistance.

See William N. ESkRIDGe, JR., Dinamic STATUTORY INTERPRETATION 107-275 (1994) for an elaboration on this argument. See also Cary Coglianese, Social Movements, Law, and Society: The Institutionalization of the Environmental Movement, 150 U. PA. L. REV. 85 (2001) (examining the environmental movement's interaction with law and society).

${ }_{2}^{2}$ See, e.g., Ruth Bader Ginsburg, Sexual Equality Under the Fourteenth and Equal Rights Amendments, 1979 WASH. U. L.Q. 161, 162 (suggesting that the Supreme Court's sex discrimination jurisprudence is defensible under a feminist understanding of equality but not as a matter of original constitutional expectations).

"For differently useful surveys of the social movements theoretical literature, see Donatella della PORTa \& Mario Diani, SOCial Movements: AN INTRODUCTION 113 (1999); and Edward L. Rubin, Passing Through the Door: Social Movement Literature and Legal Scholarship, 150 U. PA. L. REV. 1 (2001).

${ }^{4}$ See, e.g., Ralph Turner \& Lewis Killian, Collective Behavior 7 (1957) (studying how social groups influence individuals); Joseph Gusfield, The Study of Social Movements, 14 INT'L ENCYCLOPEDIA SOC. SCl. 443, 444 (1968) (analyzing the evolution of social movements in different cultures). 
rational-actor models for the origins and dynamics of different kinds of social movements. ${ }^{5}$ Political process theories address the evolving institutional contexts of social movements. ${ }^{6}$ All of these theories are relevant to lawyers' understanding of social movements and to the legal and constitutional dynamics those movements drive.

Conversely, law professors ought to be able to make some contribution to these theories. We bring our own intellectual experience with theories of the dynamics of culture and meaning, ongoing decision making under the rational-choice paradigm, and institutional and political context. ${ }^{7}$ More important, social movements are surrounded by and seek to influence law. In the modern regulatory state, we are saturated with law. Any kind of collective action, however "spontaneous" (a favorite word among social movement theorists), occurs in the context of the regulatory state. The norms challenged by this kind of collective action are likely to be codified in legal codes, and the movement's struggle will inevitably involve law. If the social movement generates institutional forms, they will be affected by and will seek to affect the law. Intuitively, the law professor would suggest that law has strong effects on social movements; law does not drive them, but it is a pervasive positive and normative context in which the social movement operates.

The social movements literature does not adequately reflect the importance of law. Consider, for example, Jean Cohen's important model for the evolution of social movements into political ones: (1) social movements arise when many individuals reject established social norms and when modes of social control cannot suppress their rejection; (2) the spontaneous action of similarly situated individuals is fol-

\footnotetext{
${ }^{5}$ See, e.g., JOHN D. MCCarthy \& MaYer N. Zald, The Trend of Social Movements in AMerica: Professionalization and Resource Mobilization 1 (1973) (emphasizing the structural conditions and resources that become available to potential social movements); CHARLes Tilly, From MOBILIZATION TO REvOLUTION 10 (1978) (examining various collective action movements, ranging from brawls to strikes); John D. McCarthy \& Mayer N. Zald, Resource Mobilization and Social Movements: A Partial Theory, in Social Movements In an Organizational Society 15 (Mayer N. Zald \& John D. McCarthy eds., 1987) (explaining the relationship of social movements to the media, government authorities, and other parties).

${ }^{6}$ See, e.g., Bert Klandermans \& Sidney Tarrow, Mobilization into Social Movements: Synthesizing European and American Approaches, 1 INT'L SOC. MOVEMENT RES. 1, 23 (1988) ("[N]ational political traditions and alignments condition the formation, the strategies, and outcomes of the new movements, however much they operate outside of politics.").

${ }^{7}$ The theories in the text generally parallel the critical, economic, and legal process methodologies honed and applied to policy and legal issues by law professors.
} 
lowed by the formation of subcultural mores and institutions, which in turn (3) generate a political movement. ${ }^{8}$ The law is marginal in her model, except as an object of political change once a social movement is underway. Cohen's model is typical; law and even legal actors usually do not show up except as bit players in the thick analysis of social movements by other influential authors. One reason law is so neglected is social scientists' adherence to Talcott Parsons's distinction among the political (legal), economic, and social spheres. ${ }^{9}$ This strikes a law professor as naive.

One goal of this Article is to suggest that social movements cannot be completely understood without getting beyond the separate spheres idea. Law and society are interconnected in many different ways. Accordingly, there ought to be an important rather than marginal role for law and legal theory in the social movements literature. I shall explore that idea in the context of a kind of social movement distinctive to the late twentieth century, the identity-based social movement (IBSM). ${ }^{10}$ Law and legal actors are critical to the instigation and

${ }^{8}$ See Jean L. Cohen, Strategy or Identity: New Theoretical Paradigms and Contemporary Social Movements, 52 SOC. REs. 663, 671-72 (1985) (evaluating competing theoretical paradigms for studying new social movements). I have reduced Cohen's six-pronged synthetic model into three prongs, but I do not think I have distorted Cohen's synthesis. For similarly influential but law-impoverished accounts of the academic object of the social movements literature, see DELLA PORTA \& DIANI, supra note 3, at 16-19; Jo Freeman, On the Origins of Social Movements, in WAVES OF Protest: SOCIAL MOVEMENTS SinCE THE SIXTIEs 7 (Jo Freeman \& Victoria Johnson eds., 1999); McCarthy \& Zald, supra note 5, at 15; and Charles Tilly, Social Movements and National Politics, in STATEMAKING AND SOCIAL MOVEMENTS 297, 305 (Charles Bright \& Susan Harding eds., 1984). Some sociologists have recognized a limited role of law for the dynamics of these new social movements. E.g., Paul Burstein, Legal Mobilization as a Social Movement Tactic: The Struggle for Equal Employmenl Opportunity, 96 AM. J. SOC. 1201, 1204 (1991) ("It is, in fact, impossible to understand the American struggle for equal opportunity without focusing on the courts and on activities intended to influence judicial decisions.").

"See Talcott Parsons, Politics and Social Structure, at ix (1969) (discussing the Parsonian treatment of political life and theory); TALCOTT PARSONS, THE SYSTEM OF MODERN SOCIETIES 2 (1971) (examining the adaptive capacity of modern societies).

11) The IBSMs discussed in this Article are similar to or the same as the "identityoriented" movements discussed by sociologists. E.g., Al.AIN TOURAINE, ThE VOICE AND THE EYE: AN ANALYSIS OF SOCIAL MOVEMENTS 31-32 (Alan Duff trans., 1981) ("The social role attributed to conflicts and in particular to class conflicts and social movements ... is an indication from the outset that I am unprepared to consider any social category whatsoever, no matter how dominated it may be, as a non-actor."); Jan Willem Duyvendak \& Marco G. Giugni, Social Movement Types and Policy Domains, in HANSPETER Kriest ET AL., NEW SOCIAL. MOVEMENTS IN WESTERN EUROPE: A Comparative ANALYSIS 82-110 (1995) (classifying new social movements according to their logic of action, including their identity orientation). Unlike many of these "new social movements" theorists, I see IBSMs as both identity-expressive and legal-instrumental. For a 
dynamics, as well as the goals, of this kind of movement. Just as law professors have much to learn from social movement scholarship about the dynamics of public law, ${ }^{11}$ so sociology professors have much to learn from us about the dynamics of social movements, or so I shall argue.

The first Part of this Article poses a descriptive, sociological-type model of the multifaceted influence of law on the birth of the primary IBSMs of the latter half of the twentieth century. Legal rules and their enforcers strongly reinforced stigmas and disadvantages that not only provided important incentives and goals for minorities, but helped give concrete meaning to the "minority group" itself. Much of what made it intelligible (as well as denigrating) to be a "colored person" or a "homosexual" or a "retarded person" was the line drawn by law and the discourse stimulated by legal actors. Naturally, therefore, the law was also one forum where the objects of the stigmas contested their status denigration. If the law was an agent of people's objectification, law's institutions were a situs for those people to reclaim their personhood. In the United States, courts as much as legislatures have been avenues for the IBSM to contest its interconnected legal and social stigmas. Most surprisingly, legal forums and actors provided the backdrop for many of the dramatic events that helped turn a nascent reform movement into a mass social movement. Once that occurred, changes in the law were inexorable. In short, law helped define the contours of the minority group itself, gave the group both incentives and forums in which to resist their stigmas, and provided dramatic events and campaigns that helped turn a reform movement into a mass social movement.

Part II of this Article develops a descriptive, sociological-type model for understanding the politics of IBSMs once they have taken off. All over the world, IBSMs have presented themselves and their goals as rights-oriented, as have their traditionalist opponents. In this country, both IBSMs and their opponents have articulated their rights as rooted in the Constitution, making those rights not just fundamental but also beyond the reach of the ordinary political process. In their effort to present their goals as beyond the political process, how-

similar understanding, see Mary Bernstein, Celebration and Suppression: The Strategic Uses of Identity by the Lesbian and Gay Movement, 103 AM. J. SOC. 531 (1997).

${ }^{11}$ See Rubin, supra note 3, at 63-83 (maintaining that contact with social movements literature enhances the ability of legal scholars to provide descriptions of and prescriptions for the legal system and offers a new approach for understanding the origin and meaning of legal concepts). 
ever, IBSMs have subjected themselves to the legal process. The phenomenon by which social groups have presented their goals in constitutional terms has had a channeling effect on both the.IBSMs and their inevitable countermovements.

The channeling effect is not one-way. Just as constitutional law has influenced the rhetoric, strategies, and norms of social movements, so the movements have affected the rhetoric, strategies, and norms of American public law. The third and final Part of the Article starts with a descriptive model of the influence of IBSMs on the evolution of public statutory and constitutional law and then turns to the primary normative question for constitutional law professors: What ought to be the role of judges in the evolution of social movements? If emerging social movements are not assured both the protections of the rule of law and, potentially, the recognition suggested by the Equal Protection Clause, the danger of violent conflict is theoretically increased. If the goal of our constitutional polity is preservation and adaptation of a peaceable pluralism, the judiciary is a necessary safety valve. Therefore, I argue that the judiciary needs to accommodate emerging social movements-as well as countermovements. Under the premises of pluralist theory, this accommodation is in the interests of the country but may not be in the interests of some elements of the social movements, for a clever judicial strategy empowers the movement, moderates over the radicals, and channels the movement's discourse in assimilative directions. I conclude that the Supreme Court's constitutional jurisprudence has usually served the pluralist polity pretty well. Its jurisprudence is less defensible if one rejects the relevance of pluralist premises for constitutional theory.

\section{A DESCRIPTIVE MODEL: LAW AND THE ORIGINS OF IDENTITY-BASED SOCIAL MOVEMENTS}

Among the most important social movements of the second half of the twentieth century were those seeking integration and equal treatment for people of color; ${ }^{12}$ equality and liberty for women, in-

${ }^{12}$ For accounts of the social movement to obtain civil rights for blacks, see DAVID J. Garrow, BEARING THE Cross: MARTIN LUTHER KING, JR., and THE SOUTHERN CHRISTIAN LEADERSHIP CONFERENCE (1986) [hereinafter GARROW, BEARING THE CROSS]; RICHARD KLUger, SIMPLE JUSTICE: THE HISTORY OF BROWN $V$. BOARD OF EDUCATION AND BLACK AMERICA'S STRUGgLE FOR EQUALITY (1976); and ALDON D. MORRIS, THE ORIGINS OF THE CIVIL RIGHTS MOVEMENT: BLACK COMMUNITIES ORGANIZING FOR CHANGE (1984). For accounts of the social movement to obtain equal rights for Native Americans, see MARK GROSSMAN, THE ABG-CLIO COMPANION 
cluding the freedom to choose contraception and abortion as means of family planning; ${ }^{13}$ rights for gay men, lesbians, bisexuals, and transgendered people; ${ }^{14}$ and equal treatment and access to opportunities for people with disabilities. ${ }^{15}$ Scholars tend to view these movements as fundamentally different from the social movements of the nineteenth and early twentieth centuries. ${ }^{16}$ The labor movement of this

TO THE NATIVE AMERICAN RIGHTS MOVEMENT (1996); THE STATE OF NATIVE AMERICA: GENOCIDE, COlonizATION, AND RESISTANCE (M. Annette Jaimes ed., 1992); and Joane Nagel, American Indian Ethnic Renewal: Politics and the Resurgence of Identity, 60 AM. SOC. REV. 947 (1995). For an account of the movement to obtain rights for Asian Americans, see ANGelo N. ANCHETA, RACE, RIGHTS, AND THE ASIAN AMERICAN EXPERIENCE (1998); for Latinos, see HISPANICS/LATINOS IN THE UNITED STATES: ETHINICIIY, RACE, AND RIGHTS (Jorge J.E. Gracia \& Pablo De Greiff eds., 2000); for Mexican Americans, see RUBÉN DONATO, THE OTHER STRUGGLe FOR EQUAL SCHOOLS: MEXICAN AMERICANS DURING THE CIVIL RIGHTS ERA (1997).

${ }^{13}$ For accounts of the women's liberation movement, see LINDA K. KERBER, NO COnSTITUTIONAL Right TO BE LAdies (1998); DEbORAH L. RHOdE, JUSTICE AND GENDER: SEX DiSCRIMINATION AND THE LAW (1989); and Jo Freeman, The Origins of the Women's Liberation Movement, 78 AM. J. SOC. 792 (1973). See also THE WOMEN'S MOVEMENTS OF THE UNITED STATES AND WESTERN EUROPE (Mary Fainsod Katzenstein \& Carol McClurg Mueller eds., 1987) (providing an international perspective). For accounts of the social movement to obtain contraception and abortion rights for women, see generally ABORTION WARS (Rickie Solinger ed., 1998); ELLLEN CHIESLER, WOMAN OF VALOR: MARGaRET SANGER AND THE BIRTH CONTROL MOVEMENT IN AMERICA (1992); NANCY F. COTT, THE GROUNDING OF MODERN FEMINISM (1987); David J. Garrow, Liberty and Sexuality: THE Right' to Privacy and the Making; OF ROE $V$. WADE (1994) [hereinafter GARROW, LIBERTY AND SEXUALITY]; KRISTIN

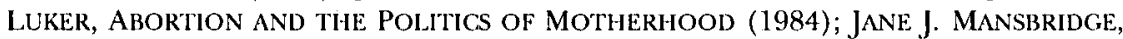
WHY WE LOST THE ERA (1986); DONALD G. MATHEWS \& JANE SHERRON DE HART, SEX, Gender, and the Politics of ERA: A State and the Nation (1990); and Suzanne Staggenborg, The Pro-Choice Movement: Organization and Activism in the ABORTION CONFLICT (1991).

${ }^{14}$ For accounts of the gay rights movement, see JOHN D'EMILIO, SEXUAL POLITICS, Sexual Communities: THE Making of a Homosexual Minority in the United States 1940-1970 (1983); and William N. Eskridge, JR., Gaylaw: Challenging the APARTHEID OF THE ClOSET (1999) [hereinafter ESKRIDGE, GAYLAW]. See also BARRY D. ADAM, THE RISE OF A GAY AND LESBIAN MOVEMENT (1987) (providing an international perspective).

15. Accounts of the disability rights movement can be found in MARTHA A. FIELD \& Valerie A. SANChez, EQUal Treatment for PEOPle WITH MENTAL Retardation (1999); DORIS ZAMES FleisCHER \& FRIEDA ZAMES, THE DISABILITY RIGHTS MOVEMENT: From Charity to Confrontation (2001); Richard K. SCOTCH, From GoOd Will. to Civil Rights: Transforming Federal Disability Policy (2d ed. 2001); Josh Gamson, Silence, Death, and the Invisible Enemy: AIDS Activism and Social Movement "Newness", 36 SOC. Probs. 351 (1989); and Richard K. Scotch, Disability as the Basis for a Social Movement: Advocacy and the Politics of Definition, $44 \mathrm{~J}$. SOC. ISSUEs 15! (1988). See also Jane Campbell \& Mike Oliver, Disability Politics: Understanding Our Past, CHANGING OUR FuTURE (1996) (detailing an account of the British disabled people's movement).

"On "new social movements" generally, see AlbERTO MELUCCI, NOMADS OF THE 
earlier period, for example, sought reallocation of economic rights and workplace entitlements. Theirs was a politics of economic redistribution. The abolitionist; temperance, and purity movements of the earlier period sought to change private as well as public ethics and moral practices. Theirs was a politics of morality. Although ultimately entailing some economic redistribution and seeking to revise public morality, the new social movements of the late twentieth century sought to change the status of marginalized groups. Theirs was a politics of recognition. ${ }^{17}$ For these civil rights, women's liberation, prochoice, gay liberation, and disability rights movements, the core goal was to force society to recognize the movements' constituents as equal citizens and persons who were just as worthy as the social normnamely, the white heterosexual male.

Law and legal discourse played an unusually important role in the formation of these IBSMs. Indeed, legal rules and institutions were keys to each of three preconditions for an IBSM. ${ }^{18}$ First, law helped define a class of people whose social identity was dominated by a legally stigmatizing trait. The extra economic and psychic costs imposed by law gave various groups stronger reasons to band together and to transform social attitudes. Second, legal institutions simultaneously provided stigmatized minorities with forums where they could

Present: SOCIAL MOVEmENTS ANd Individual NEEDS IN CONTEMPORARY Society (1989); Bert Klandermans, New Social Movements and Resource Mobilization: The European. and American Approach, 4 INT'L J. MASS EMERGENCIES AND DISASTERS 13 (1986); and supra note 10, which identifies additional sources. See also RICHARD L. ABEL, SPEAKING, RESPECT, RESPECTING SPEECH 69-124 (1998) (examining the politics of respect and the ability to contest social status); JOEL F. HANDLER, SOCIAL MOVEMENTS AND THE LEgAI SYSTEM: A THEORY OF LAW REFORM AND SOCIAL CHANGE, at xi (1978) (detailing new social movements' successes in the arena of law reform); J.M. Balkin, The Constitution of Status, 106 YALE L.J. 2313, 2321-32 (1997) (discussing cultural movements centered on social status and group identity); Nancy Fraser, From Redistribution to Recognition?: Dilemmas of Justice in a "Postsocialist" Age, in JustiCe InTERRUPTUS: CRITICAL REFlections ON THE "POSTSOCIALIST" CONDITION 18-19 (1997) (exploring the social motivations of the gay rights movement).

${ }_{17}$ Nancy Fraser has commented that

Gays and lesbians suffer from heterosexism: the authoritative construction of norms that privilege heterosexuality ... . The remedy for the injustice, consequently, is recognition, not redistribution. Overcoming homophobia and heterosexism requires changing the cultural valuations (as well as their legal and practical expressions) that privilege heterosexuality, deny equal respect to gays and lesbians, and refuse to recognize homosexuality as a legitimate way of being sexual.

Fraser, supra note 16, at 18-19. For parallel ideas in the legal literature, see ABEL, supra note 16, at 69-124, and Balkin, supra note 16, at 2321-32.

${ }^{14}$ See Freeman, supra note 13, at 802 (describing the preconditions for the stirring of a social movement). 
object to exclusion and discrimination. Sometimes legal actors directly prodded minorities to object; more often, governmental forums provided minorities with opportunities to form informational networks. Third, other legal actors hostile to minorities gave minority agenda entrepreneurs the crises or dramatic events they needed to trigger mass mobilization against stigmatizing policies and attitudes. In short, the mass mobilization characteristic of IBSMs in the twentieth century was not easily possible without the state as both adversary (state enforcers) and ally (legislatures sometimes, the judiciary more often).

\section{A. The Seeds of IBSMs: Legalized Discriminations and World War II}

At the end of World War II, when America's campaign of freedom against the Nazis was ending and America's campaign of freedom against the Communists in the Cold War was beginning, citizens of the United States lived under a caste system. People were categorized and privileged (or not) according to various identifying traits. Important preferences and higher status were accorded persons who were white, male, heterosexual, mentally and physically healthy, Protestant, right-handed, slender, and good-looking (in a Cary Grant/Deborah Kerr sense). Persons encountered limits and disadvantages if they were nonwhite, female, homosexual, disabled, Jewish or Catholic, lefthanded, overweight, or ugly. Such persons occupied a lower status than those who possessed the desired traits. Between 1945 and 2000, mass social movements formed around the traits of race, sex, sexual orientation, and disability. ${ }^{19}$ They did not form around the traits of religion, ethnicity, left-handedness, weight, or attractiveness.

The main variable that sorts the movement-generating traits from the others is whether or not the law deployed the trait as the basis for a regulatory regime that valorized the dominant characteristic and

${ }^{19}$ One could also add rich/poor to my list of preference-generating traits, and poor people did organize in social movements. See generally FRANCIS FOX PIVEN \& Richard A. ClOWARD, POOR PEOPle's MOVEMENTS: WhY THEY SUCCEED, HOW THEY FAIL 2 (1979) (outlining the evolution of poverty movements); MARTHA F. DAVIS, BRUTAL NEED: LAWYERS AND THE WELFARE RIGHTS MOVEMENT, 1960-1973, at 3 (1993) (exploring the origins and evolution of the welfare rights movement). I do not address poor people's movements because they are more like traditional redistributive movements (akin to the labor movement) than to identity movements such as the civil rights one. The politics of redistribution thoroughly dominates the politics of recognition in poor people's movements. Thus, the welfare rights movement of the late $1960 \mathrm{~s}$ was less interested in promoting poverty as "good," or even "tolerable," and much more interested in providing life essentials for people on welfare. 
imposed exclusions and hardships on those possessing the subordinate characteristic. Law circa 1945 pervasively discriminated on the basis of race, sex, sexual orientation, and disability:

Criminal Sanctions. There were special criminal sanctions aimed at regulating certain minorities' control of their own bodies and sexualities. It was a crime in every state for a woman to have an abortion, usually with a potentially malleable exception. ${ }^{20}$ Oral and anal sex between consenting adults was a crime in every state. ${ }^{21}$ In many states it was a crime to have sex with a mentally disabled person. ${ }^{22}$ In most jurisdictions, it was both a state and municipal crime for a woman or a homosexual man to solicit sex from a man or to engage in sex for compensation. $^{23}$ In southern states, sex between people of different races was a crime; a black man accused (often without foundation) of raping a white woman usually faced execution, either by law or by lynch mobs. ${ }^{24}$ All over the country, vagrancy and loitering laws were aimed at the disruption of presumably illicit activities by people of color, homosexuals, and unmarried women. ${ }^{2.5}$ In most major cities, it was a crime to cross-dress in public. ${ }^{26}$ At least one metropolis made it a crime for a "diseased, maimed, mutilated, or in any way deformed"

${ }^{20}$ See Roe v. Wade, 410 U.S. 113, 17477 (1973) (Rehnquist, J., dissenting) (providing a state-by-state account of abortion laws).

${ }^{21}$ See ESKRIDGE, GAYLAW, supra note 14, at app. Al (listing state consensual sodomy laws).

${ }^{22}$ See Susan Stefan, Whose Egg Is It Anyway?: Reproductive Rights of Incarcerated, Institutionalized and Incompetent Women, 13 NOVA L. REV. 405, 410-27 (1989) (discussing state regulation of the reproductive rights of women who are incarcerated, institutionalized, or adjudicated incompetent).

${ }^{23}$ See ESKRIDGE, GAY_AW, supra note 14, at 29-31, app. A2 (detailing lewd solicitation statutes).

${ }^{24}$ Jacquelyn Dowd Hall, "The Mind That Bums in Each Body": Women, Rape, and Racial Violence, in Powers of Desire: The Polltics of Sexuality 328, 334 (Ann Snitow et al. eds., 1983); see JOHN D'Emilio \& Estelle B. FreEdman, InTImATE MATTERS: A History OF SEXUALITY IN AMERICA 105-07 (1988) (detailing how sexuality became one of the central means of reasserting white social control over blacks during Reconstruction); LEON F. LITWACK, BEEN IN THE STORM TOO LONG: THE AFTERMATH OF SLAVERY 274-91 (1979) (describing how white Southerners dominated blacks through the use of intimidation, violence, and discriminatory laws during Reconstruction).

${ }^{25}$ See generally David J. PIVAR, Purity Crusade: Sexual Morality and Social CONTROL, 1868-1900, at 204-77 (1973) (discussing how purity reformers developed a political movement to destroy prostitution); RUTH ROSEN, THE LOST SISTERHOOD: ProstituTION IN AMERICA, 1900-1918, at 1-50 (1982) (describing how Americans attempted to legislate morality during the Progressive Era by abolishing prostitution).

${ }^{26}$ See ESKRIDGE, GAYLAW, supra note 14, at app. A2 (listing the municipalities criminalizing cross-dressing). 
person to be found in any of the "public places in this city."

State Control of the Body. At any point in your life as one of these legally stigmatized minorities, the state could exercise normative control over how you deployed your body. For example, the United States detained Japanese-American citizens in camps during World War II without any finding of criminal activity. ${ }^{28}$ More than 116,000 people with mental and other kinds of disabilities were hospitalized by the state, usually without their consent, and subjected to any number of medical tortures. ${ }^{2.9}$ As of 1950 , thirty-one states authorized the sterilization of people with specified disabilities; more than 70,000 people were so treated by the state during the twentieth century. ${ }^{30}$ Women who were also racial minorities were most commonly subjected to state-sanctioned sterilization." ${ }^{31}$ By 1961, twenty-nine states and the District of Columbia required the hospitalization of "psychopathic persons," a term that was often a code for homosexuals." In state hospitals, people charged with sex crimes, as well as the disabled, were

${ }^{27}$ FLEISCHER \& ZAMES, supra note 15, at 12 (quoting a Chicago ordinance of 1911, which was repealed in 1974).

28 See Page Smith, Democracy on Trial: The Japanese American Evacuation AND RELOCATION IN WORLD WAR II, at 170-237 (1995) (detailing the relocation of Japanese Americans into Assembly Centers).

${ }^{29}$ Field \& SANCHEZ, supra note 15 , at 67 ; see R.C. SCHEERENBERGER, A HISTORY OF MENTAL RETARDATION 158 (1983) (presenting documentation of the increase in the number of mentally retarded persons admitted to institutions from 1900 to 1930).

"Judith AREen, CaSes and Materials on Family LaW 982 (3d ed. 1992); see FIELD \& SANCHEZ, supra note 15 , at $67-68$ (discussing the advent of the eugenics movement as the subjection of institutionalized persons to compulsory sterilization); DANIEL J. KeVles, IN THE NAME OF Eugenics: GeNeTICS AND THE USES OF HuMAN HEREDITY 110-12 (1985) (discussing Buck v. Bell in which the Supreme Court upheld the sterilization of the plaintiff because the state determined that she, her mother, and her daughter were "feebleminded," thereby falling within the scope of a Virginia sterilization statute); Paul K. Longmore, The Life of Randolph Bourne and the Need for a History of Disabled People, 13 Revs. AM. Hist. 581, 584 (1985) (reviewing BruCE CLAYToN, FORGOTTEN PROPHET: THE LIFE OF RANDOLPH BOURNE (1984)) (describing sterilization and mercy killings of people with disabilities, as a matter of state law); Note, $\mathrm{Hu}$ man Sterilization, 35 IOWA L. REV. 251, 253 nn.12, 13 (1950) (listing state sterilization statutes that were enacted following the decision in Buck $\%$. Bell).

${ }^{31}$ See Carlos C. Velez-I., The Nonconsenting Sterilization of Mexican Women in Los Angeles, in TWICE a Minori'T: Mexican AMERICAN WOMEN 235, 239-40 (Margarita B. Melville ed., 1980) (describing how Mexican women were sterilized in public hospitals without their consent or after coercive measures were taken to obtain consent in order for medical students to gain experience in sterilization procedures).

${ }^{32}$ See ESkRIDGe, GaYlAw, supra note 14, at app. B1 (listing "sodomy," "unnatural acts," and "crimes against public morals" as state sexual psychopath laws); PHILIP Jenkins, Moral Panic: Changing Concepts of the Child Molester in MOdern AMERICA 49-93 (1998) (discussing "sex psychopaths" and statutes aimed at preventing sex crimes). 
subjected to chemical and electrical experimentation. ${ }^{33}$ Working-class women were often incarcerated for prostitution and other sex offenses. Women of all classes were theoretically subject to state control of their bodies through restrictive abortion laws. ${ }^{34}$

Limitations in Ability to Form Families. States refused to recognize homosexual marriages, interracial marriages, and marriages to or between mentally and sometimes physically disabled people. ${ }^{35}$ These unions were often considered crimes as well. For women, marriage meant a loss of rights. The most notable example was that married women were subject to rape by their husbands without any legal recourse because of state laws preserving "marital rape exemptions." People with disabilities and homosexuals were considered per se unfit parents, and their children were sometimes taken away from them by the state without their consent. ${ }^{37}$

Voting Exclusions. People of color were disenfranchised in the South through intimidation, poll taxes, and discriminatorily administered literacy tests and other registration requirements. ${ }^{38}$ Sexual and

${ }^{33}$ See Samuel Liebman, Electroshock: My Vision of the World on Fire, in GAY AMERICAN HiSTORY: LESBIANS AND GAY MEN IN THE U.S.A. 170 (Jonathan Katz ed., 1976) (presenting a doctor's case study of the effect of electroshock therapy on a homosexual).

${ }^{34}$ Cf. LUKER, supra note 13, at 45-46 (discussing how medical discretion to perform therapeutic abortions was exercised in a completely haphazard way, such that the chance of getting a therapeutic abortion seems to have been almost completely random).

35 See William N. ESkridge, JR., The CaSe for Same-Sex Marriage 87-122 (1996) (documenting traditional American refusal to recognize lesbian or gay marriages); The Mentally Disabled and The LAW 226-29 (Samuel J. Brakel \& Ronald S. Rock eds., rev. ed. 1971) (discussing the bar in most states against allowing people with mental disabilities to marry); Herbert Hovenkamp, Social Science and Segregation Before Brown, 1985 DUKE L.J. 624, 624-25, 635 (noting that interracial sexuality was taboo and illegal in most of America before the war).

${ }_{36 .}$ See Jill Elaine Hasday, Contest and Consent: A Legal History of Marital Rape, 88 CAL. L. REV. 1373, 1375-1406 (2000) (giving a history of the marital rape exemption in the nineteenth century); Jaye Sitton, Note, Old Wine in New Bottles: The "Marital" Rape Al lowance, 72 N.C. L. REV. 261, 261-68 (1993) (explaining the common law marital rape exemption). See generally DIANA E.H. RUSSELl, RAPE IN MARRIAGE (1982) (discussing "wiferape"); Rebecca M. Ryan, The Sex Right: A Legal History of the Marital Rape Exemption, 20 LAW \& SOC. INQUIRY 941, 941-47 (1996) (discussing the history of the marital rape exemption).

${ }^{37}$ See FIELD \& SANCHEZ, supra note 15, at 20, 350 n.68 (discussing states with explicit rules against parenting by people with mental disabilities); Rhonda R. Rivera, Our Straight-Laced Judges: The Legal Position of Homosexual Persons in the United States, 30 HASTINGS L.J. 799, 883-904 (1979) (discussing discrimination against lesbian and gay parents in custody battles).

${ }^{38}$ See LeON F. Litwack, Trouble in Mind: Black Southerners IN THE Age OF JIM CROW 218-29, 363-73 (1998) (detailing how some blacks had to brave threats and 
gender minorities were theoretically disenfranchised if they were convicted of sodomy or lewdness or other "crimes of moral turpitude."

Immigration Exclusions. Since the late nineteenth century, American federal immigration policy had excluded immigrants because of their race or ethnicity. ${ }^{40}$ The McCarran-Walter Act of 1952 carried forward most of the earlier race-based exclusions, as well as exclusions of people "afflicted with psychopathic personality"-a code word for homosexuals and bisexuals ${ }^{41}$-epileptics and people with other specified physical disabilities, ${ }^{42}$ people who were "feeble-minded" or "insane," and women whom immigration authorities suspected of being "prostitutes."

Jury Exclusions. People of color and women were routinely excluded or-in the case of women-excused from juries in many states either by law or by discriminatory use of peremptory challenges. ${ }^{45}$ Open homosexuals and people with disabilities were probably excluded by reason of challenges.

Employment Exclusions. The federal government and most state governments would not employ homosexuals in either the civil or

violence in order to vote); Frank R. Parker et al., Mississippi, in QUIET REvOLUTION IN THE SOUTH: THE IMPACT OF THE VOTING Rights ACT, 1965-1990, at 137-38 (Chandler Davidson \& Bernard Grofman eds., 1994) (describing how through the use of literacy tests, other similar requirements, and violence, whites diluted black voting power in the South).

${ }^{99}$ See Hunter v. Underwood, 471 U.S. 222, 227 (1987) (striking down an Alabama law that disenfranchised people convicted of consensual sodomy, inter alia, because the law was drafted with the intent to disenfranchise people of color, against whom sodomy laws were disproportionately applied).

40 See generally IAN HANEY López, White by LaW: THe Legal CONSTRUCtion of RACE 37-39 (1996) (describing the operation of race-based exclusions in immigration policies).

${ }^{41}$ Immigration and Nationality Act, Pub. L. No. 82-414, § 212(a) (4), 66 Stat. 163, 182 (1952), construed in Boutilier v. INS, 387 U.S. 118, 118 (1967).

${ }^{42}$ See $\S 212(\mathrm{a})(4)$ (epileptics); $\$ 212(\mathrm{a})(5)$ (drug addicts and alcoholics); $\$ 212(\mathrm{a})(6)$ (those afflicted with tuberculosis); $\$ 212(\mathrm{a})(7)$ (others having a "physical defect, disease, or disability").

${ }^{43} \$ 212(a)(1)-(2)$.

${ }^{44} \S 212(\mathrm{a})(12)-(13)$.

${ }^{4.5}$ On the exclusion of African Americans from juries until the 1960s, see RANDALL KENNEDY, RACE, CRIME AND THE LAW 168-80 (1997). Even in mid-century, women's jury service was typically voluntary, whereas men's was compulsory. See Fay v. New York, 332 U.S. 261, 289-90 (1947) (noting that in 1942 only twenty-eight states allowed women to serve on juries and, in fifteen of those twenty-eight states, they might claim an exemption because of their sex); see also Hoyt v. Florida, 368 U.S. 57, 59-63 (1961) (holding that a jury without women is constitutional); KERBER, supra note 13, at 124220 (discussing women's limited role in juries throughout history). 
military service. ${ }^{46}$ People of color were often excluded from higherstatus government jobs and were typically segregated in the workplace, most prominently in the U.S. armed forces. ${ }^{47}$ Women were excluded by law from many jobs, including prime roles in the armed forces, some professions (through state-sponsored licensing commissions), and various other occupations like running a bar. ${ }^{48}$ The armed forces and some civil service employers would not accept people with disabilities.

Education Discrimination. In much of the United States, education was segregated by race and sometimes by ethnicity; minorities almost always got inferior facilities and resources as a result of this arrangement. $^{49}$ While some states denied public education altogether to many people with disabilities, ${ }^{50}$ others separated mentally disabled children from their families to commit them to facilities that were "educational" in name, but brutally punitive in effect. ${ }^{51}$ Women were usually discouraged by state and local authorities from seeking higher

46 See ESKRIDGE, GAYLAW, supra note 14, at 67-74 (relating the desire of some government officials to rid homosexuals from government jobs and military service).

${ }^{47}$ See generally BERNARD C. NALTY, STRENGTH FOR THE FIGHT: A HiSTORY OF BLACK AMERICANS IN THE MILITARY (1986) (describing the armed forces' traditional exclusion of, then segregation of, people of color).

48 Se JEANNE HOLM, WOMEN In THE Militaky: AN UNFINISHEd REvOlution 68-79 (1982) (describing the armed forces' traditional exclusion of, and later discrimination against, women); SUSAN LEHRER, ORIGINS OF PROTECTIVE LABOR LEGISLATION FOR WOMEN 1905-1925, at 3-40 (1987) (discussing how a woman's place was thought to be in the home and not in the working world).

49 See Henry allen Bullock, A History of Negro Education in the South, FROM 1619 TO THE PRESENT $167-93$ (1967) (discussing segregation of black school children and the inherent unfairness of the separate but equal doctrine); GILBERT G. Gonzalez, Chicano Education in the ERA OF SEgregation $21-22$ (1990) (discussing a mid-1930s study that found that eighty-five percent of surveyed districts in the Southwest contained segregated schools for Mexican-American children); KLUGER, supra note 12, at 169 (describing the inadequate facilities and instructors available to blacks as a result of school segregation); Robert S. Chang, Toward an Asian-American Legal Scholarship: Critical Race Theory, Post-Structuralism, and Narrative Space, $81 \mathrm{CAL}$. L. REV. 1243, 1293 (1993) (describing school segregation of Asian-American children).

50 See, e.g., Bd. of Educ. v. State ex rel. Goldman, 191 N.E. 914, 916 (Ohio Ct. App. 1934) ("As a matter of common sense it is apparent that a moron of very low type, or an idiot or imbecile who is incapable of absorbing knowledge or making progress in the schools ought to be excluded."); FLEISCHER \& ZAMES, supra note 15, at 12 (describing the expulsion of a disabled child in Wisconsin).

${ }^{51}$ See RuTH Colker, The LAW OF Disability Discrimination: CaSES AND MATERIALS 4-5 (1995) (identifying state statutes that mandated segregation of the "feeble-minded" in institutions and discussing cases that addressed the institutionalization of disabled individuals). 
education. $^{52}$ Homosexuals were sometimes expelled from state colleges and universities for consensual sexual activities.

Public Facilities and Transport. Southern states had a comprehensive array of laws requiring the segregation of people of color from white people in public transportation, municipal swimming pools and parks, restaurants and hotels, public drinking fountains and restrooms, and a myriad of other facilities. ${ }^{54}$ The other minorities were not expressly governed by this kind of exclusion, but the effect of state policies had an analogous effect on them. Whereas black people were physically segregated by law, many disabled people were de facto segregated in separate institutions, most homosexuals were psychically segregated in the closet, and most women were essentially confined to the home by state and social pressures.

Nothing like this regime of government discrimination afflicted religious, ethnic, and body-weight or physical-appearance minorities. The contrast between racism, sexism, and homophobia on one side, and anti-Semitism on the other, is especially striking. Jews have been the object of vicious and continuous social discrimination in the United States, but in 1945 they were generally not the objects of open discrimination as a matter of law. ${ }^{5.5}$ Accordingly, Jews in the twentieth century did not mobilize in a mass social movement the way AfricanAmericans or gays and lesbians did.

It is incorrect to say that legal exclusions and stigmas were a sufficient condition for an IBSM, ${ }^{5 i j}$ but they seem to have been a necessary

See Barbara Miller Solomon, in the company of Educated Women: A HISTORY OF WOMEN AND HIGHER EDUCATION IN AMIEICA 172-85 (1985) (discussing the debate over whether women of the $1920 \mathrm{~s}, 30 \mathrm{~s}$, and ' $40 \mathrm{~s}$ should be allowed to pursue higher education instead of raising a family).

5.: See William N. Eskridge, Jr., Privacy Jurisprudence and the Apartheid of the Closet, 1946-1961, 24 FLA. ST. U. L. REV. 703, 749-50 (1997) (reporting dozens of students who were expelled or who withdrew from the University of Florida in response to the state's anti-homosexual witch hunt).

5ee generally LITWACK, supra note 24 (discussing southern "Jim Crow" laws).

See, e.g., LlonARD DinNERSTEIN, ANTISEMITISM IN AMERICA 154-55 (1994) (noting that although numerous state laws prohibited employment discrimination against Jews in the 1940s and '50s, Jews continued to suffer from unofficial or private discrimination).

Many other disabilities and discriminations embedded in law related to traits that did not give rise to identity-based social movements. Such traits include intelligence, age (for the most part), and addiction. Because society as a whole and even those who are disadvantaged by these traits-the less intelligent, the elderly, and the addicted-continue to believe that such traits serve legitimate social functions, they have not generated social movements challenging exclusions and discriminations based on them. 
condition: they helped trigger IBSMs that otherwise would not have developed. The law not only helped define the class of people stigmatized by their defining traits, but also strongly contributed to the class's willingness to challenge not only legal, but also social stigmas. The law did that by simultaneously raising the costs of the stigma and bringing members of the stigmatized class together, both physically and intellectually. The law did not assure that minority people would form a social movement, for law could also raise the costs of objecting to stigmatic exclusions. The particular configuration of public law in the mid-twentieth century was probably a precondition for a series of IBSMs and pressed these otherwise different movements toward strikingly similar rhetoric, agendas, and political dynamics. ${ }^{57}$

\section{Defining the Class and the Disadvantage}

Law contributed to the process by which groups of otherwise dissimilar people came to feel that they were, because of their classification, "similarly situated." Because law helped render particular traits salient and ensured that they would be the subject of official discourse and application, it contributed to rigidly conceptualized trait-based identities. One's identity as a "colored" man was reinforced by language in the statute books and the proceedings in courts and administrative tribunals. One could say that social attitudes preceded and motivated legal rules, ${ }^{58}$ but during the apartheid period those rules did more than reflect social attitudes. For birth certificates, voting, licensing, and other government-sponsored activities, state officials needed to categorize every person by race in order to enforce the apartheid regime. In this way, segregation yielded an ongoing public as well as private attention to race, and a discourse about who was "colored" and who was not." This was also true at the national level:

${ }^{57}$ I do not equate the birth control, women's, pro-choice, gay rights, civil rights, and disability rights movements. They were distinct movements with different features. For example, the first four movements involved gender roles in ways not directly implicated by the last two. Sexuality and reproduction, in contrast, were expressly implicated in all six. The civil rights movement was uniquely linked with slavery. The birth control, women's, and pro-choice movements related to cooperative arrangements between men and women. The birth control, pro-choice, and gay rights movements implicated conduct more directly than the others. And so on.

${ }_{58}$ There is reason to debate this proposition because the social attitudes were themselves the product of slavery, creating a legal as well as social institution that resulted in longstanding rules and regulations that treated "colored" people differently from "white" people.

59 See, e.g., HANEY LóPEZ, supra note 40, at 111-53 (analyzing the legal discourse by 
officials of the armed forces and immigration officers had to make race-based determinations for every person who served in the military or tried to immigrate to the United States. ${ }^{60}$ Some people resisted their state-based racial categorizations, and a few litigated the matter all the way to the Supreme Court." Likewise, one's identity as "mentally retarded" was a legal determination and not purely a natural one. Carrie Buck, the defendant sterilized by Virginia in the leading case of Buck $v$. Bell, ${ }^{62}$ was ruled to be congenitally feebleminded, a determination that medical examinations later suggested was unfounded. ${ }^{63}$ Scholars maintain that the diagnosis of feeblemindedness was a consequence of racial, class, and gender biases as much as scientific measurements of people's intelligence. ${ }^{64}$

Law's entrenchment of sexual orientation as a totalizing social trait was just as dramatic. Women who were sexually attracted to other women had little in common with men attracted to other men except by operation of law and social attitudes. By the end of World War II, military policy had established lesbians and (male) "homosexuals" as similarly predatory and unfit for military service. ${ }^{65}$ After

which race was determined); SCOTT L. MALCOMSON, ONE DROP OF BLOOD: THE AMERICAN MISADVENTURE OF RACE (2000) (tracing the evolution of race in American society); Ariela J. Gross, Litigating Whiteness: Trials of Racial Determination in the Nineteenth Century South, 108 YALE L.J. 109 (1998) (examining trial records where racial determinations were made); Eva Saks, Representing Miscegenation Law, 8 RARITAN 39 (1988) (analyzing miscegenation law from the first case in 1819 through the last case in 1970).

(6) See HANEY López, supra note 40, at 45, 59, 88-89 (describing categories drawn by immigration officials to enforce race-based exclusions); see also Gerald Torres \& Kathryn Milun, Translating Yonnondio by Precedent and Evidence: The Mashpee Indian Case, 1990 DukE L.J. 625 (arguing that judicial application of the Non-Intercourse Act depended on whether a group continuously qualified as an American Indian tribe).

61 The most famous was Homer Plessy, whose African-American great-grandparent led the state and federal judiciary to classify him as "colored" in Plessy v. Ferguson, 163 U.S. 537, 541 (1896). For background on Plessy $v$. Ferguson, see CHARLEs A. Lofgren, THE PLESSY CASE: A LEGAI-HISTORICAL INTERPRETATION 5 (1987). See HANEY López, supra note 40 , for an exhaustive study of judges' and administrators' race judgments in immigration cases.

274 U.S. 200 (1927).

6. See KEVLES, supra note 30, at 110-12 (noting that evidence of Carrie Buck's low intelligence would be considered weak today, and that her daughter was considered bright ).

${ }^{64}$ See Stephen Jay Gould, Carrie Buck's Daughter, 2 CONST. COMmENT. 331 (1985) (analyzing Buck $v$. Bell and arguing that Carrie Buck in fact was not mentally disabled). See generally Ruth Colker, Hybrid: Bisexuals, Multiracials, and Other Misfits UNDER AMERICAN LAW 163-93 (1996) (discussing the identification and treatment of the disabled by the law).

On the evolution of the exclusion of homosexual men, see ALLAN BÉRUBÉ, 
the war, "homosexuals and sex perverts" of both sexes were firmly established in the statute books and case law, not only as outlaws but also as supposed child molesters episodically hunted by the state. ${ }^{6 i}$ Moreover, the sex-regulatory state worked with Puritan social norms to create a pervasive discourse about homosexuality. Policemen, army doctors and navy investigators, liquor inspectors, public school boards and principals, film and book censors, FBI agents, state investigating committees, immigration officials, and other agents of the federal, state, and local government interrogated people about their own and other people's sexuality. ${ }^{67}$ These interrogations yielded social knowledge that not only reinforced the salience of sexual orientation as an identity trait but also created curiosity about it. For example, many first realized they were homosexuals after they had been interrogated by state agents, such as the doctors who examined military recruits during World War II. ${ }^{68}$

Law also played a role in the overdetermination of sex and gender. Cross-dressing laws explicitly served to police gender conformity, even as to attire. Marriage and birth certificate requirements contributed to doctors' snap binary judgments about a newborn's sex- "it's a boy" or "it's a girl"-that were sometimes oversimple and occasionally flat wrong." State policies "protecting" women against working in certain occupations or for longer hours than men, excusing them from compulsory service on juries and the armed forces, and rewarding them for marriage to men were more indirect policies reinforcing the traditional notion of separate spheres, whereby men operated in the

COMING OUT UNDER FIRE: THE HISTORY OF GAY MEN AND WOMEN IN WORLD WAR TwO (1990). Regarding the exclusion of lesbians, see LEISA D. MEYER, CREATING GI JANE: SEXUALITY AND POWER IN THE WOMEN'S ARMY CORPS DURING WORLD WAR II 158-59 (1996).

6r See George Chauncey, Jr., The Postwar Sex Crime Panic, in True STORIES from THE AMERICAN PAST 160, 170 (William Graebner ed., 1993) (discussing the rise of public hysteria over sex crimes against children and women during the early 1950s and the resulting societal response to those perceived as sexually deviant, including homosexuals); Estelle B. Freedman, "Uncontrolled Desires": The Response to the Sexual Psychopath, 1920-1960, 74 J. AM. HIST. 83, 94 (1987) (discussing how the police frequently targeted homosexuals when rounding up "perverts" and child molesters).

${ }^{67}$ See D'Emilio, supra note 14, at 41-48 (detailing the many examples of state interrogation about sexual orientation).

${ }^{6}$ BÉRUBÉ, supra note 65, at 22-25, 243-44.

${ }^{69}$ See, e.g., John Money et al., An Examination of Some Basic Sexual Concepts: The Evidence of Human Hermaphroditism, 97 BULL. JOHNS HOPKINS HoSP. 301, 301 (1955) ("Despite advancements of knowledge in embryology and endocrinology, most people have continued to make an absolute dichotomy between male and female .....). 
public sphere and women in the domestic one. ${ }^{70}$

Legal discriminations also provided concrete manifestations of inchoate social prejudices and stereotypes that could be identified and challenged. Racism and homophobia were sprawling social attitudes or collections of beliefs not easily susceptible to open discourse or resistance by their victims. ${ }^{71}$ There was not a clear process for changing those attitudes, either in individuals or in society as a whole. Because attitudes could be cloaked, one could not even know whether one has ever refuted or erased them. In contrast, racist statutes or antihomosexual rules of enforcement were much more concrete targets. The person of color or the homosexual could identify the state's stance and, oftentimes, the rationale undergirding it. There were established procedures for changing or modifying the rules. That which could be identified could be resisted, and official rationales could be refuted or debated. Their debate and reform or repeal could be conducted wholesale-society-wide-and not just retail-individual by individual.

The modern era thrives on sharply drawn classifications and concrete rules. Law is the epitome of both. If an IBSM consists of persons and their allies who resist their stigmatization because of bad classifications, and requires concrete advances to attract members (as we shall see below), law is all but necessary for such a movement to exist.

2. Raising the Costs of the Stigmatized Trait and Lowering the Costs of Challenging the Trait

Another effect of law was to raise the costs of the stigmatized trait to the minority person. If Jews were excluded from Harvard and Yale in the 1920 s because of their ethnicity, they could still go to public universities, such as City College, and their pre-college public school

${ }^{70}$ See, e.g., Alice Kessler-Harris, OUt to Work: A History OF Wage-Earning WOMEN IN THE UNITED STATES 181 (1982) ("[Protective labor legislation] therefore bears some of the responsibility for successfully institutionalizing women's secondary labor force position."); JULIE A. MATTHAEI, AN ECONOMIC HiSTORY OF WOMEN IN AMERICA: WOMEN'S WORK, THE SEXUAL DIVISION OF LABOR, AND THE DEVELOPMENT OF CAPITALISM 217-18 (1982) (arguing that protective labor legislation for women was enacted to limit the competitive effect that their lower wages were having on working men as well as to preserve women for their roles as homemakers and mothers).

${ }^{71}$ A literature along these lines matured after World War II. See, e.g., GoRDon W. AllPORT, The NAture OF PREJUdice 12-13, 371 (abr. ed. 1958) (arguing that prejudice consists of an attitude of favor/disfavor stemming from an overgeneralized belief, a combination that often becomes entrenched in one's personality). 
education helped them achieve an upward mobility. When the state has internalized the social norm, the costs of the stigma to the pariah are higher. Thus, people of color growing up in the South were not only excluded from prestigious private universities and colleges such as Duke and Davidson, but also from all public institutions such as the Universities of Texas and Virginia. Nor did they have much hope of getting into Harvard and Yale, because apartheid limited their aspirations even at the grade and secondary school levels. Similarly, women were excluded from most prestigious institutions of learning, ${ }^{72}$ and their pre-college education was not encouraging.

Education is merely one example of the effect of state discrimination on a social group. State discrimination raised the tangible disadvantages for stigmatized groups in other ways as well. People of color and homosexuals were more likely to be arrested and sent to prison than whites and heterosexuals. The mentally retarded and homosexuals were more likely than their mainstream counterparts to be incarcerated in psychiatric institutions and tortured physically as well as mentally. Women, people of color, and disabled folks were less likely to have access to government jobs and, hence, were likely to have overall lower incomes than white men without disabilities. Homosexuals, people with disabilities, and persons attracted to differentrace partners were unable to marry the people with whom they were in love and were, instead, episodically persecuted for what the state considered forbidden love.

For many marginalized Americans, the greatest cost of state stigma was intangible, taking the form of shame that they internalized as a consequence of pervasive state and social signals. This was the point of the "doll studies": African-American children ashamed of their own skin color preferred white dolls over darker ones. ${ }^{73}$ Gay people and people with disabilities felt a similar shame. Their deviation from the normal, however, was something much worse than a misfortune: it

72 See, e.g., United States v. Virginia, 518 U.S. 515, 536-37 (1996) (documenting the long-time exclusion of women from public and private universities).

${ }^{73}$ See Kenneth B. Clark \& Mamie P. Clark, Racial Identification and Preference in Negro Children, in READINGs SOC. Psychol. 169, 175-78 (Theodore M. Newcomb \& Eugene L. Hartley eds., 1947) (describing a controlled test where African-American children were asked to pick racially marked dolls according to which doll they liked "best," which doll was "nice," or which doll looked "bad"); see also Patricia J. Williams, Comment, Metro Broadcasting, Inc. v. FCC: Regrouping in Singular Times, 104 HARV. L. REV. 525, 542-43 (1990) (relating author's experience of passing by a five-and-dime store and observing a bin of identically molded doll sets for sale: white doll sets for $\$ 3.99$, and black doll sets for $\$ 1.99$ ). 
was felt as a mark of Cain, a moral as well as psychic or physical defect. ${ }^{74}$ State discrimination played an indeterminate but surely significant role in this internalized stigma.

In short, when the law, as well as society, engages in trait-based shaming and discrimination, the cost of the norm is higher, and possibly much higher, to stigmatized persons. This higher cost provides a reason for marginalized people to engage in activism to change the norm through well-established procedures to change a law. The high cost of a stigma, however, does not provide a sufficient reason for this activism; the rational person will not participate in a social movement if the costs of participation are higher than the expected benefits. Southern states were able to sustain apartheid in part by making it very costly for people of color to protest the arrangement. Dissidents were met with social ostracism, loss of employment, state harassment, and sometimes imprisonment or lynching. ${ }^{75}$ The NAACP, the primary civil rights organization for decades, was originally organized in the North, where the costs of organizing were much lower than in the South. ${ }^{70}$

For similar reasons, homosexuals not only failed to organize against state discrimination, but few even dared to come out of their closets before the 1960s. The only homophile organization founded between 1900 and 1951 was in Chicago. The local police busted the organization and arrested its founder, Henry Gerber, who also lost his job with the postal service. ${ }^{77}$ Not only was the state able to abort this effort at social reform, but its draconian response had a deterrent effect for years to come. In contrast to people of color and homosexuals, women and some disabled people were able to organize before the war because the state did not mobilize against them. Their organizations were able to achieve some political progress-including federal programs for disabled veterans, ${ }^{78}$ local and state laws requiring

${ }^{74}$ See, e.g., Bertram J. Cohler \& Robert M. Gal.atzer-Levy, The Course of Gay And Lesbian lives: Social And Psychoanalytic Perspectives 263-73 (2000) (describing the shame and self-hatred felt by homosexuals as a result of antigay prejudice); Ilan H. Meyer, Minority Stress and Mental Health in Gay Men, 36 J. HEALTH \& SOC. BEHAV. 38, 40 (1995) ("Long before they begin to realize their own homosexuality, homosexually-oriented people internalize societal antihomosexual attitudes.").

${ }^{75}$ See LITWACK, supra note 38 , at 217-79 (detailing the means by which southern society discouraged black resistance and organization).

7i See generally ChARLES FlinT KellogG, NAACP 9-45 (1967) (recounting the early history of the NAACP).

${ }^{77}$ See Henry Gerber, The Society for Human Rights-1925, ONE, Sept. 1962, at 5 (giving a first-person account of his arrest, trial, and discharge from the postal service).

${ }^{78}$ See FLEISCHER \& ZAMES, supra note 15 , at 170-74 (describing veterans' rehabilita- 
accommodations for blind people, ${ }^{79}$ and suffrage for women as well as national debate over the ERA, which was first introduced in the 1923 session of Congress. ${ }^{80}$

One feature of American law that potentially reduces the costs of social dissent is objectors' access to courts that will protect them. Before 1945, the Supreme Court had set forth constitutional principles that potentially served to protect dissidents from government censorship. In 1925, for example, the Court suggested that the First Amendment applied to the states, ${ }^{81}$ a constitutional assumption amplified by subsequent cases protecting political speech against state syndicalism laws and prior restraints. ${ }^{82}$ Theoretically, the NAACP and homophile groups could rely on the Freedom of Speech Clause of the First Amendment to protect their members, but as of 1945 it was not clear exactly what the Speech Clause protected. For example, nothing in the Speech Clause protects people's freedom to associate, nor was it clear that the clause covered expressive conduct, like marching. Furthermore, there was reason to doubt that federal judges would stick their necks out for despised minorities, especially in those parts of the country most hostile to them. In short, people of color and homosexuals were unable to organize effectively, in substantial part because officers of the law as well as private citizens could be expected to retaliate with impunity against activists.

\section{Shared Group Consciousness}

A social group defined and penalized by legal stigmas will not have an incentive to organize so long as most of its members view their stigma as justified, acceptable, or inevitable. Although modern educated discourse considers it shameful for someone to have attitudes that are racist, sexist, or homophobic, throughout most of American history educated folks thought that way. In 1900, people

\footnotetext{
tion programs adopted after both world wars).

${ }^{79}$ See SCOTCH, supra note 15, at 28-29 (discussing the guide dog laws and white cane laws enacted to accommodate blind people starting in the 1930s).

"No See MANSBRIDGE, supra note 13, at 8-14 (providing an early history of the ERA); Verta Taylor, Social Movement Continuity: The Women's Movement in Abeyance, 54 AM. SOC. REV. 761, 762-64 (1989) (describing a peak in the women's movement during the period between 1900 and 1920 ).

${ }^{81}$ Gitlow v. New York, 268 U.S. 652, 666 (1925), overmuled on other grounds by Dennis v. United States, 341 U.S. 494 (1951).

${ }^{82}$ De Jonge v. Oregon, 299 U.S. 353, 365-66 (1937) (overturning a conviction under a state's syndicalism law); Near v. Minnesota ex rel. Olson, 283 U.S. 697, 722-23 (1931) (holding unconstitutional a state's prior restraint law).
} 
stigmatized because of their race, sex, disabilities, or (what we call) sexual orientation would have accepted, for the most part, their degraded status as natural or acceptable or would have just acquiesced in "the way things are." Other circumstances were necessary before a stigmatized social group could form a consensus that its subordination was unjustified. Those circumstances were falling into place during the 1940 s, in part owing to government and the law.

The most important variable was probably urbanization, which concentrated blacks and homosexuals in big cities and offered women the prospect of smaller families and more employment opportunities. $^{83}$ Urbanization generally occurred without state action, but the state accelerated the effects of urbanization on minority consciousness with the greatest governmental venture of the last century: World War II. $^{84}$ The war's unprecedented mobilization of an entire country was a tremendous stimulus to minority "groupthink," as it brought people of color and homosexuals into the war effort, albeit as second-class citizens, and put millions of women and people with disabilities to work on the home front. ${ }^{85}$ Accordingly, women experienced the responsibilities of work outside the home, people of color experienced the responsibilities of military service, and homosexuals experienced the responsibilities of fighting side by side with heterosexuals-and most of them not only enjoyed the new roles thrust upon them, but also were proud of their own contributions. By putting "colored" people together into segregated units, throwing women together in sex-segregated workforces, and reminding homosexuals of their stigma at the same time the armed forces were throwing men together into situations that often became sexualized, the state's war effort had

${ }^{83}$ Numerous authors have commented on the concentration of Americans in big cities and its effect on minority groups. See, e.g., CAROLINE BIRD ET AL., WHAT WOMEN WANr 106 (1979) (linking women's job opportunities outside the home to their equality demands); LITWACK, supra note 38, at 481-96 (describing the migration of blacks to northern cities during the twentieth century); John D'Emilio, Capitalism and Gay Identity, in POWERS OF DESIRE, supra note 24, at 100, 105-08 (emphasizing the importance of capitalism and urbanization for gay people's consciousness).

${ }^{84}$ On the synergistic effect of World War II and urbanization, see D'EMILIO, supra note 14, at 29; HAROLD R. ISAACS, THE NEW WORLD OF NEGRO AMERICANS 41-44 (1963); NeIl A. WYNN, THE AFro-AmERICAN AND THE SECOND World WAR 12-20 (1976); Richard M. Dalfiume, The "Forgotten Years" of the Negro Revolution, $55 \mathrm{~J}$. AM. HisT. 90, 99-100, 102 (1968).

S5. See generally BÉRUBÉ, supra note 65 (relating the war experience ut homosexuals); FLEISCHER \& ZAMES, supra note 15, at 12-13 (relating the war experience of people with disabilities); MORRIS J. MACGREGOR, JR., INTEGRATION OF THE ARMED FORCES: 1940-1965 (1989) (detailing the integration of the U.S. military); MEYER, supra note 65 (relating the war experience of women). 
the effect of promoting a group consciousness among stigmatized minorities. ${ }^{86}$ After the war normalization returned with a vengeance; people of color went back to hometown apartheid, women and blind people lost their wartime jobs, women married to mother the baby boom, and homosexuals were hounded out of the armed forces and the federal government in a series of witch hunts and purges. But these people, who were supposed to be at the bottom of society, had enjoyed a shared taste of camaraderie with fellow group members and a taste of equality with straight white men-and many of them could not get it out of their systems. Trait-based disadvantages that were accepted as natural or inevitable before the war became grating and contingent after the war. Also, the war created a whole new class of disabled people: paralyzed veterans.

Another cluster of state policies fueled this aborning solidarity with information and ideas that undermined the foundations of stigmatizing discrimination. A central policy of the modern American state has been public education available to all. This policy yielded high levels of literacy in the United States by mid-century, and the expanding literate public had some access to ideas and books that criticized old prejudices and stereotypes. An educated person is much more likely to object to a stigma, and certain books created an informal national network of minority readers thinking along the same iconoclastic lines. Although the public school system loyally indoctrinated children with traditional myths and stereotypes, the publicschooled black person read An American Dilemma ${ }^{87}$ and Invisible Man ${ }^{88}$ and realized that his resentment at serving a country with racist policies was widely shared. The literate lesbian read The Well of Loneliness ${ }^{89}$ and realized that other women felt as she did, while the homosexual read about scientific papers criticizing the idea that homosexuals were mentally ill, and started thinking that the shrinks were the crazy ones. Similarly, educated women read A Room of One's Own, ${ }^{90}$ Planned Par-

${ }^{86}$ But cf. ERving Goffman, Asylums: Essays on the Social Situation of MENTAl PATIENTS AND OTHer InMates 24-33 (1961) (providing examples of certain situations where stigmatized people do not necessarily form social groups).

${ }^{87}$ GUNNAR MYrDal, AN AMERICAN Dilemma (1944) (giving a devastating depiction of American racism and apartheid).

${ }^{88}$ RALPH ELLISON, INVISIBLE MAN (1947) (providing a searing account of the marginalization and erasure of a human being because of his race).

${ }^{89}$ RADCLYFFE HALL, THE WELL OF LONELINESS (1928) (presenting a liberating depiction of love between women).

90 VIRGINIA WOOLF, A ROOM OF ONE'S OWN (1929) (rejecting the patriarchal idea that women must exist only in relation to their husbands and children). 
enthood's pamphlets, and magazine articles on abortion and realized that women all over the world were taking control of their own bodies and minds. Local governments often tried to censor literature and magazines bringing subversive ideas and images into their locales, but the judiciary was usually willing to overturn these efforts. ${ }^{91}$ Public education also worked synergistically with the federal government's opposition to, and then war against, Nazi Germany. Even before our entry into World War II, American state policy and educated opinion were hostile to fascism, and many Americans were associating the $\mathrm{Na}$ zis' racist and eugenic philosophy with hated fascism. Both minorities and some mainstream Americans identified our democracy as standing resolutely against prejudice-and came to believe that our own apartheid and other discriminations were inconsistent with our ideals and our anti-totalitarian stance. ${ }^{92}$ The Nazis, in short, gave racism and eugenics a bad name. This process continued after World War II, when Communism replaced fascism as the alien enemy. ${ }^{93}$

\section{B. State Forums as a (Partial) Solution to Collective Action Problems}

Even if many individuals realize they would be better off working together to end or reduce discrimination against them, and even if they could engage in activism with little cost, few of them will actually contribute to the collective good. Limiting the production of "public goods," which are goods shared by all members of the group, is the free rider problem: unless sharing the public good can be denied to those who do not contribute to its formation, individuals in the group

"See, e.g., United States v. One Package, 86 F.2d 737, 739-40 (2d Cir. 1936) (protecting birth control materials from seizure); People ex rel. Savery v. Gotham Book Mart, 285 N.Y.S. 563, 568-70 (N.Y. City Magis. Ct. 1936) (protecting the autobiography of homosexual author André Gide); VERA BRITTAIN, RADCLYFFE HAL.L: A CASE OF OBSCENITY? 147-49 (1968) (explaining a court's decision to overturn censorship of The Well of Loneliness).

"92 See, e.g., Carl. N. Degler, In Search of Human Nature: The Decline and REVIVAl. OF DARWINISM IN AMERICAN SOCIAL THOUght, 202-05 (1991) (arguing that anti-Nazi feelings dampened enthusiasm for eugenics among Americans); Mary L. Dudziak, Desegregation as a Cold War Imperative, 41 STAN. L. REV. 61, 68-70 (1988) (arguing that anti-Nazi feelings called American apartheid into question); Richard Weiss, Ethnicity and Reform: Minorities and the Ambience of the Depression Years, $66 \mathrm{~J}$. AM. HIST. 566, 571-72 (1979) (arguing that anti-Nazi feelings supported tolerance for a wide range of American minorities).

(93 As to the importance of anti-Communism to the American anti-apartheid movement, see Derrick A. Bell, Jr., Brown v. Board of Education and the InterestConveyance Dilemma, 93 HARV. L. REV. 518, 524 (1980); Dudziak, supra note 92, at 73-76. 
have insufficient incentives to contribute. ${ }^{94}$ Why should I engage in a costly activity when I shall share in the benefit regardless of my level of participation? If most people think this way, few will contribute to the public good, and comparatively little of it will be produced.

The free rider problem, however, does not foreclose group organization completely. Minority group members and their sympathizers who gain positive benefit or utility from working with like-minded reformers toward a goal they value for its own sake, will still engage in activism, notwithstanding the failure of most other group members to contribute. Also, sympathetic outsiders can create organizations that virtually represent the interests of minorities without any participation by beneficiaries in the early stages. Associations staffed by such groupminded altruists or agenda entrepreneurs can be viewed as elite organizations because they are staffed by a small number of the relatively advantaged and well-educated members of the minority or its sympathizers. Primary examples of such organizations from the mid-twentieth century include the National Association for the Advancement of Colored People (NAACP), Planned Parenthood, the National Federation of the Blind (NFB), the National Women's Party (NWP), and the Mattachine Society and the Daughters of Bilitis (early homophile groups). ${ }^{95} \quad$ It is easier for elite organizations to petition agencies, courts, and legislatures than to change public opinion directly. If any of these state organs is receptive to the reformist message of the elite organizations, the reformers can make headway and thrive. The above-listed organizations followed a variety of different strategies, depending on the nature of their claims and the institutional motivations of the possible state audiences. All of the strategies depended critically on appeals to unelected judges and administrators.

Minority groups whose members were subject to intense community prejudice had little choice but to appeal primarily to the judiciary. State and (especially) federal judges were relatively more receptive to

${ }^{94}$ See Dennis C. Mueller, Public Choice II, at 11 (1989) ("The impossibility of exclusion raises the likelihood that purely voluntary schemes for providing a public good will break down."); MANCUR OLSON JR., THE LOGIC OF COLLECTIVE ACTION: PUBLIC GOODS AND THE THEORY OF GRouPS 2 (rev. ed., Schocken Books 1971) (1965) (describing the disincentives for individuals to contribute to group action).

${ }_{95}$ For accounts of these groups, see D'EMILIO, supra note 14, at 57-125, discussing homophile groups; GARROW, LIBERTY AND SEXUALITY, supra note 13, at 1-37, 100-06, discussing Connecticut's Planned Parenthood and its predecessor association; SCOTCH, supra note 15, at 33-34, discussing the NFB; MARK V. TUSHNET, THE NAACP'S LEGAL STRA'tegy AGAINST SEgREgATED EdUCATION, 1925-1950 (1987), discussing the NAACP; and Taylor, supra note 80 , profiling the NWP. 
these groups than legislators were because judges were partly insulated from local political pressure and were more committed to the constitutional values of due process, equal protection, and free expression and association." Also, the lack of a large membership base was less of a disadvantage for elite organizations when they were suing in court than when they were petitioning the legislature. While the judiciary was the best hope for such groups, this did not ensure that the hope would be anything but hollow. For their own institutional and political reasons, however, federal judges in the mid-twentieth century were willing to respond to these groups by recognizing universal human rights under the U.S. Constitution."

The NAACP was the primary organizational critic of race-based discriminations in the prewar period, and its strategy for change was dominated by constitutional challenges to segregation laws in federal court. This organization, dedicated to resisting the principle and policies of apartheid, never enjoyed a large membership, and people of color were not, for most of the century, a potent political group, even in the northern states. While the NAACP energetically publicized the wrongs of segregation and persuaded many intellectuals of the rightness of its agenda, moral suasion had little impact on legislatures. In contrast, federal judges were a receptive audience, partly because of their comparative independence and partly because they were responsible to a national constituency that was increasingly embarrassed by the racist policies of the South. ${ }^{! /}$For example, the aggressive deployment of the death penalty against people of color accused (often without foundation) of raping white women found no effective remedies in the legislatures or courts of the South, but fed-

The statements in the text are, on the whole, more characteristic of federal than state judges because the former are appointed for life and do not have to be confirmed by local electors or legislative bodies, while the latter typically are elected for fixed terms and are relatively more beholden to local opinion.

${ }^{97}$ On the strong conceptual turn from positivism and toward universal human rights among Supreme Court Justices, see David M. Bixby, The Roosevelt Court, Democratic Ideology, and Minority Rights: Anolher Look at United States v. Classic, 90 YALE L.J. 741, 746-79 (1981), and Robert M. Cover, The Origins of Judicial Activism in the Protection of Minorities, 91 Yale L.J. 1287 (1982). See also Richard A. Primus, ThE AMERICAN LANGUAGE OF RIGHTS 180, 180-233 (1999) ("A major change in American conceptions of rights occurred sometime between the $1920 \mathrm{~s}$ and the 1960s, but many scholars fail to give sufficient emphasis to anti-totalitarianism and especially anti-Nazism when trying to account for that transformation.").

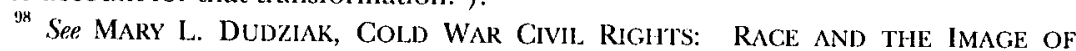
AMERICAN DEMOCRACY 95-101 (2000) (discussing the successes of the NAACP before the Supreme Court); Bixby, supra note 97 , at 762-79 (documenting individual Justices' views on civil rights circa 1940 ). 
eral judges found the practice barbaric. The Supreme Court's construction of the Due Process Clause requiring state-appointed counsel in death penalty cases came as a result of precisely such a prosecution. $^{99}$ The federal judiciary, moreover, was populated by New Deal lawyers and activists who were more sympathetic to the plight of the disenfranchised than the old order of judges had been. Civil rights attorneys and the new order of federal judges formed a symbiotic relationship that proved incredibly fruitful.

The NAACP Legal Defense Fund, Inc. (the "Inc. Fund") in the 1940s and 1950s successfully challenged particular apartheid laws and practices as violations of the Due Process and Equal Protection Clauses. ${ }^{101}$ The New Deal Court, appalled by the predicament of racial minorities and the racist policies permeating the South, was determined to shape constitutional law to eradicate racially motivated injustice. ${ }^{102}$ Once this judicial inclination became clear, civil rights lawyers openly challenged the apartheid regime itself. ${ }^{103}$ In a careful litigation campaign, the NAACP drew support from local activists, national advocates, and its own lawyers to bring a series of cases seeking racial integration of the public schools. After a series of small victories, in which the Court invalidated specific instances of segregation but not the overall practice, the NAACP won a momentous legal victory in Brown $v$. Board of Education, ${ }^{104}$ where the Court ruled that de jure racial segregation of public schools is inconsistent with the Equal Protection

${ }^{99}$ Powell v. Alabama, 287 U.S. 45, 49-50, $71-73$ (1932); see Moore v. Dempsey, 261 U.S. 86, 92 (1923) (overturning a state conviction tainted by lynch mob pressure). Both cases are discussed in KENNEDY, supra note 45, at 94-104.

${ }^{100}$ For a glimpse of this symbiosis, see the first-hand account in Philip Elman, The Solicitor General's Office, Justice Frankfurter, and Civil Rights Litigation, 1946-1960: An Oral History, 100 HARV. L. REv. 817, 824-26 (1987), discussing the coordinated strategy by civil rights attorneys and some of the Supreme Court Justices to wait and gain strength before attempting to overrule Plessy $v$. Ferguson in the legal fight to end discrimination.

101 The string of successful NAACP-sponsored lawsuits began with Guinn $v$. United States, 238 U.S. 347, 367 (1915), which declared grandfather clauses used to take the vote from blacks to be violative of the Fifteenth Amendment, and ran through Brown $v$. Board of Education, 347 U.S. 483, 495 (1954), which outlawed segregation in public schools, and continued with cases implementing Brown. See generally KLUGER, supra note 12 (discussing the many nuances of Brown and placing them in the context of the civil rights movement); TUSHNET, supra note 95, at 1-2 (describing the NAACP coordinated litigation campaign of 1925 to 1950 ).

${ }^{102}$ See Bixby, supra note 97, at 762-79 (providing documentation for the motivations of most of the Justices in the 1940s).

${ }^{103}$ See TUSHNET, supra note 95, at 114-15 (describing how in 1948 the NAACP resolved to attack apartheid directly).

104347 U.S. at 495. 
Clause. Brown did not immediately result in desegregation, however. It merely stimulated a decades-long process by which school boards, episodically prodded by judges and powerfully prodded by the federal Department of Health, Education and Welfare (HEW) after 1965, were forced to adopt school systems that did not discriminate on the basis of race. ${ }^{105}$

Both before and after Brown, local groups of African Americans challenged busing segregation policies in the South. The most celebrated challenge was the boycott organized in Montgomery, Alabama, after activist Rosa Parks refused to sit in the back of a bus. The Montgomery bus boycott, which thrust Dr. Martin Luther King, Jr. into national prominence and spawned the Southern Christian Leadership Conference (SCLC) as a grassroots complement to the NAACP, was resolved in favor of the boycotters by the Supreme Court's invalidation of Montgomery's bus segregation laws in November $1956 .^{106}$ In the case of the seminal Montgomery boycott, the role of Brown was threefold. First, Brown emboldened people of color to work together by increasing the likelihood that federal judges would support their campaign. ${ }^{107}$ Second, the ultimate success of the boycott was not as-

${ }^{105}$ Numerous authors have presented a variety of perspectives on the uneven implementation of Browon. See DERRICK A. BELl, JR., RACE, RACISM, AND AMERICAN LAW 594-60l (3d ed. 1992) (noting the obstacles to proper implementation that allow for continued racial segregation in America's schools); J. HARVIE WILKINSON, III, FROM BROWN TO BAKKE. THE SUPREME COURT AND SCHOOL INTEGRATION: $1954-1978$, at 6669 (1979) (defending the Court's implementation decision in Brown II as pragmatically sound); Paul Gewirtz, Choice in the Transition: School Desegregation and the Corrective Ideal, 86 COLUM. L. REV. 728, 755 (1986) (taking note of the "freedom of choice" alternative to implementation by government-ordered integration).

Iff Gayle v. Browder, 352 U.S. 903, 903 (1956) (per curiam); see MORRIS, supra note 12 , at 63 (detailing the court's decision and discussing its import). For an account of the bus boycotts of the 1950s, see $i d$, at 17-25, 40-76.

${ }^{107}$ See Garrow, BeARING THE Cross, supra note 12, at 59-63 (noting how blacks in Montgomery rallied behind King and the bus boycotts while the legal process moved along); Martin Luther King, JR., Stride Toward Freedom: THE Montcomery STORY 53, 191 (1958) (providing a first-hand account of the Montgomery boycott). Michael Klarman argues that Brown had only some, but not much, inspirational effect on civil rights activists. Michael J. KJarman, Brown, Racial Change, and the Civil Rights Movement, 80 VA. L. REV. 7, 77-79 (1994). Although there is much evidence to dispute Klarman's claims, see id. at 77 n.333 \& 79 n.342 (collecting sources); David J. Garrow, Hopelessly Hollow History: Revisionist Devaluing of Brown v. Board of Education, 80 VA. L. REV. 151, 152-57 (1994) (demonstrating Brown's direct relevance to the success of the Montgomery bus boycott), my assertion does not depend on an inspirational theory alone: for rational actors considering whether to instigate or cooperate in the Montgomery bus boycott, Brown increased the odds of success and the costs of white resistance. For a more radical critique of Brown's impact, see GERALD N. ROSENBERG, THE Hollow Hope: Can Courts Bring About Social Change? 107-56 (1991). 
sured until the Supreme Court applied Brown to invalidate Montgomery's policy of bus segregation. ${ }^{108}$ Third, in part because of Brown, several of the violent showdowns between boycotters and law enforcement attracted unprecedented national press coverage to the struggle against apartheid and helped turn opinion against the segregationists. $^{109}$

Homosexuals scored fewer litigation successes before 1961 but, like civil rights groups, looked to the courts as primary venues for advancing their goals within a system that discriminated against them. This decision is an easy one to understand; legislators were almost unrelentingly hostile to "degenerates," "psychopaths," and "sex perverts," as homosexuals were labeled in the statute books. While hardly friendly to gay litigants, judges were less hostile to their interests and modestly protected homophile efforts to preserve spaces for their association and information-sharing. New York courts in the 1930s, for example, enjoined state censorship of books realistically depicting lesbian and gay lives. ${ }^{110}$ The first public homophile association was the Mattachine Society, whose initial public relations coup came in the courtroom, where it successfully defended (on grounds of entrapment) one of its members who had been arrested for lewd solicitation. ${ }^{11}$ The first public homophile publication was One magazine, published by One, Inc. When the United States Postal Service im-

${ }^{108}$ Because the Supreme Court decision affirming the lower court decision against bus segregation in Montgomery, Gayle, 352 U.S. at 903, came on the same day that a state judge had enjoined the boycott under state law as unfair competition with the bus companies, African-American boycotters received an immediate victory and the faith to persevere in their worthwhile cause. See GARROW, BEARING THE CROSS, supra note 12, at 80-82 (discussing the sense of relief and high emotion felt in response to the Supreme Court's decision).

109 See GARROW, BEARING THE CROSS, supra note 12, at 63-66, 70-75 (discussing the change in sentiment as Montgomery blacks and whites came under increased media attention). In a recurring pattern, the civil rights bus victory was followed by a white backlash that included violence against blacks. See id. at 83-86 (describing attacks on King, associates of King, and Montgomery bus riders following the legal victory). See generally Klarman, supra note 107, at 11, 141-49 (arguing that Brown's greatest contribution was to trigger violent white resistance in the South, which mobilized more progressive opinions on civil rights in the North).

${ }^{110}$ See, e.g., People ex rel. Savery v. Gotham Book Mart Inc., 285 N.Y.S. 563, 570 (N.Y. City Magis. C. 1936) (holding that material about homosexual life did not violate an obscenity statute).

${ }^{111}$ See Dale Jennings, To Be Accused Is to Be Guilly, ONE, Jan. 1953, at 12-13 (giving a first-person account of the man charged with lewd solicitation); see also STUART Timmons, THE Trouble WITH Harry Hay: Founder of THE MOdern Gay MOVEMENT 163-68 (1990) (exploring the role of Dale Jennings' lewd solicitation case as a milestone in the Mattachine Society's evolution). 
pounded copies of its October 1954 issue on grounds of obscenity, the journal went to court and ultimately won a ruling that the impoundment was unconstitutional, in the first Supreme Court opinion protecting homosexuals against state intrusion. ${ }^{112}$ Judges in New York and the District of Columbia imposed burdens of proof on prosecutors that slowed down police dragnets of male homosexuals after the war. ${ }^{113}$ During the 1950s, the California Supreme Court protected gay bars from being closed down by the state simply because "homosexuals and sex perverts" hung out in them. ${ }^{114}$ None of these victories was as momentous as the NAACP's victory in Brown, and for every court victory there were a dozen rebuffs.

Women were neither as dependent on nor as successful as African Americans and gay people in seeking the aid of judges in advancing their equality interests. Before 1970, there was no feminist litigating group comparable to the NAACP's Inc. Fund, and equal protection challenges to the many state statutory sex discriminations were uniformly unsuccessful at the Supreme Court until 1971..$^{1.5}$ An Equal Rights Amendment was introduced in Congress as early as 1923 and developed broad general support; but it did not pass both chambers of Congress until 1972, and even that effort failed at the state ratification stage. ${ }^{116}$

Women's most controversial claims were for the control of the conditions of their pregnancies. A rule of thumb was that when women could form coalitions with established male groups, like doctors and lawyers, they could achieve their goals in the legislature. Courts were most useful when those coalitions were blocked by intensely interested local groups, especially religious ones. Margaret Sanger's birth control movement, for example, first sought judicial nullification or narrowing of anti-contraception laws. Although Sanger went to jail, the New York Court of Appeals construed the anti-

${ }^{112}$ One, Inc. v. Olesen, 355 U.S. 371,371 (1958) (per curiam).

${ }_{114}$ See ESKRIDGE, GAYLAW, supra note 14, at 85-86 (describing these cases).

${ }^{114}$ II. at 93-95 (describing a California case where the court held that a well-known gay bar could not have its license revoked "without proof of the commission of illegal or immoral acts on the premises").

115. See, e.g., Goesaert v. Cleary, 335 U.S. 464, 467 (1948) (upholding a Michigan statute forbidding licensed female bartenders except in instances where they were the wives or daughters of male liquor establishment owners).

${ }^{11 i}$ Sie MANSBRIDGE, supra note 13, at 8-10 (discussing the progress of the Equal Rights Amendment through Congress and barriers to the Amendment posed by several women's organizations); RHODE, supra note 13, at 63-80 (recounting the failed ERA campaign). 
contraception law to allow physician-recommended birth control. ${ }^{117}$ Sanger's approach was a rational strategy for an elite organization without powerful political support. Once the Supreme Court signaled interest in enforcing the Speech Clause, lower court judges narrowed the federal Comstock Act to allow birth control devices and information to flow freely across state lines. ${ }^{118}$ At the state level, Sanger and her allies worked through legislation as well as lawsuits. Most state laws barring dissemination of contraceptives or birth control advice were formally repealed by legislatures, but it required constitutional decisions by the Supreme Court to clear away the remaining laws in Griswold v. Connecticut ${ }^{19}$ and Eisenstadt v. Baird. ${ }^{120}$

The pro-choice movement also demonstrates how elite organizations could work through legislatures as well as courts to achieve their goals. Abortion reform efforts in the 1960 s generally were pressed by elite organizations of doctors and lawyers (the American Law Institute (ALI) and the National Association for the Repeal of Abortion Laws (NARAL), founded in 1968) and did not reflect mass involvement by women. Legislatures in California and nine other states adopted laws reflecting the abortion reform perspective of the ALI in the late 1960s. In 1970, Hawaii enacted a repeal law reflecting the NARAL approach, followed by New York, Alaska, and Washington. ${ }^{121}$ Unlike black and gay groups before them, the pro-choice movement succeeded in state

${ }^{117}$ People v. Sanger, 118 N.E. 637, 683 (N.Y. 1918), appeal dismissed, 251 U.S. 537 (1919); see MARGARET SANGER: AN AUTOBIOGRAPHY 216 (Dover Publications, Inc. 1971) (1938) (chronicling the opening of the first American birth control clinic).

${ }_{118}$ See United States v. One Package, 86 F.2d 737, 740 (2d Cir. 1936) (holding that the Comstock Act does not bar importation of physician-prescribed birth control devices); United States v. Dennett, 39 F.2d 564, 569 (2d Cir. 1930) (holding that the Comstock Act cannot be applied to the distribution of sex education materials).

${ }^{119} 381$ U.S. 491,516 (1965) (striking down Connecticut's ban on contraception as violative of the sanctity of the home and the rights of married persons). By 1940, only Connecticut and Massachusetts had absolute bars on the distribution of birth control devices, but their Roman Catholic-dominated legislatures were unlikely to repeal the laws. Birth control advocates lost in state court challenges and won at the U.S. Supreme Court only after a quarter-century of effort. See Tileston v. Ullman, 318 U.S. 44, 46 (1943) (per curiam) (rejecting a physician's challenge to a state statute prohibiting the giving of advice about the use of contraceptives because he lacked standing); Poe v. Ullman, 367 U.S. 497,503 (1961) (barring a challenge to the same law challenged in Tileston as not "ripe").

${ }^{120} 405$ U.S. 438, 453 (1972) (invalidating Massachusetts's contraception regulations on the basis that the right of privacy protects an individual from "unwarranted governmental intrusion into matters so fundamentally affecting a person as the decision whether to bear or beget child").

${ }^{121}$ The reform and repeal efforts are described in LAWRENCE LADER, ABORTION II: MAKING THE REVOLUTION 70, 116-18, 172 (1973). 
legislatures because abortion choice advocates were well organized, represented elite (medical) opinion, and could plausibly claim to represent the views of the largest voting block in the state-women.

Nonetheless, women also litigated with remarkable success. Perhaps judges recognized the emerging pro-choice movement as a political force to be reckoned with, a force which could be accommodated because its pro-choice constitutional arguments fit within several lines of substantive due process precedent. The first big litigation victories involved claims that abortion laws with exceptions for the mother's "health" were too vague to provide doctors notice of what is unlawful, as required by the Due Process Clause. The California and U.S. Supreme Courts declined to invalidate abortion laws on this ground but construed the mother's health allowance to include the mother's mental as well as physical health. ${ }^{122}$ Activists also maintained that abortion on demand was entailed in the Griswold/Eisenstadt privacy cases. The pro-choice victory in Roe $v$. Wade went beyond anybody's expectations in sweeping away all state abortion laws, including the liberalized ones in California and other states.

If a minority group were able to win the support of executive department officials, it could sometimes achieve results legislatures are unwilling to give and courts unable to direct. The best-known example is the desegregation of the United States armed forces, which was ordered by President Truman in 1948. ${ }^{123}$ For a less well-known example, the President's Committee on the Employment of the Handicapped (PCEH) was created after World War II in order to promote the employment of disabled veterans. Although the PCEH mainly concerned itself with traditional education and rehabilitation programs, it created a focal group of activists through the annual meetings it sponsored on disability issues. The network of disability activists spawned by these meetings worked toward better programs for the disabled and objected to state and federal discrimination against people with disabilities. Although the PCEH and other disability rights

${ }^{122}$ See United States v. Vuitch, 402 U.S. 62, $71-72$ (1971) (requiring that the prosecution prove that an abortion was not needed for the preservation of the mother's physical or mental health or life); People v. Belous, 458 P.2d 194, 205 (Cal. 1969) ("Thus, the test established is a medical one, whether the pregnant woman's physical and mental health will be furthered by abortion or by bearing the child to term, and the assessment does not involve considerations beyond medical competence.").

${ }^{123}$ See Richard M. DAlfiume, DeSEgregation of THE U.S. ARMEd Forces: Fighting ON Two Fronts, 1939-1953, at 115-121 (1969). See generally MACGrEgor, supra note 85 (describing the fall of the legal, administrative, and social barriers to black Americans' full participation in the United States armed forces). 
groups had modest successes in Congress and with the executive before $1973,{ }^{124}$ their most dramatic pre-1973 victories were in federal courts. Federal judges of the 1960 s and 1970 s were hostile to any law or practice which broadly excluded disabled people from public education or other services. ${ }^{125}$

\section{A Prophylactic First Amendment and Over-Enforcement of Discriminatory Laws as Triggers for Mass Social Movements}

As the foregoing account suggests, law contributed to group consciousness and motivation to seek greater equality by people of color, gay people, women, and people with disabilities; it also offered forums (especially courts) where even small and despised minorities could press their claims. But the NAACP, the Mattachine Society, Planned Parenthood, NWP, NFB, and the PCEH groups did not constitute mass social movements, because they were not able to mobilize great numbers of the minority on behalf of their causes. The last stage in the creation of a social movement is the mobilization of many people, notwithstanding collective action problems. At this point, a psychological change occurs: what were previously considered personal "costs" in making sacrifices for a collective good (change in the law) became "benefits" for a lot more people. The dynamics of collective action start to seem less like a prisoners' dilemma game and more like an assurance game. Everyone understands that joint action would benefit them all and would like to participate in the creation of this public good, but no one is inclined to participate unless everyone else (or a specified portion of the group) is also participating or is expected to participate. ${ }^{126}$

Law mattered critically in the transition of a reform movement led by elite organizations (NAACP, Mattachine, NWP, PCEH) to a mass social movement, where lots of people spontaneously became in-

${ }^{124}$ See SCOTCH, supra note 15, at 139-68 (describing federal administrative and legislative measures taken to protect the rights of disabled people).

125. See id. at 37-40 (describing federal court decisions assuring equality for children with disabilities).

${ }^{126}$ Dennis Chong, Collective Action and the Civil, Rights Movement 103140 (1991). On assurance games generally, see Thomas A. Schelling, Hockey Helmets, Concealed Weapons, and Daylight Savings: A Study of Binary Choices with Externalities, $17 \mathrm{~J}$. CONFLICT RESOL. 381, 383-406 (1973), analyzing in technical and graphical fashion binary choices with externalities, as found with coalitions, in the context of the prisoner's dilemma framework; and Amartya K. Sen, Isolation, Assurance, and the Social Rate of Discount, 81 Q.J. ECON. 112, 113-15 (1967), discussing problems arising with the assurance game, including the need for enforcement. 
volved. $^{127}$ Different legal actors unwittingly contributed in different ways. The Supreme Court created an enormous constitutionally protected public space for dissent and protest. Under the auspices of the Speech Clause, the Supreme Court ruled that state and local governments could not censor unorthodox or disrespectful identity speech, nor vituperative criticisms of traditional policies; ${ }^{128}$ were barred from outlawing or probing dissident organizations and associations; ${ }^{129}$ had to allow protest marches and rallies (subject to nondiscriminatory time, place, and manner restrictions); ${ }^{130}$ could not harass unconventional people without probable cause that they were violating a legitimate law; ${ }^{|3|}$ could not discipline state teachers and other employees simply because of their public political expression; ${ }^{132}$ and were required to allow objectionable groups equal space at public colleges and universities. ${ }^{133}$ This body of law came together as an elaborate program of strongly libertarian rules between 1963 and 1972, with virtually no coordinated or effective opposition from state and federal

${ }^{127}$ I am thinking specifically of the civil rights movement's sit-ins and 1963 March on Washington; the pro-choice as well as the women's liberation movements of the $1960 \mathrm{~s}$; and the gay liberation movement of the 1970s.

${ }^{128}$ See Cohen v. California, 403 U.S. 15, $25-26$ (1971) (protecting an anti-draft jacket with an emblazoned obscenity); Brandenburg v. Ohio, 395 U.S. 444, 448 (1969) (per curiam) (striking down a law that prohibited the Ku Klux Klan from advocating violence and law-breaking); Bond v. Floyd, 385 U.S. 116, 135-37 (1966) (holding that a state legislator has the right to make statements supporting those who choose to burn their draft cards).

129 See Gibson v. Fl. Legislative Investigation Comm., 372 U.S. 539, 557-58 (1963) ("[G]roups which themselves are neither engaged in subversive or other illegal or improper activities... are to be protected in their rights of free and private association."); NAACP v. Alabama ex rel. Patterson, 357 U.S. 449, 466 (1958) (protecting the NAACP from state attempts to view its membership lists).

${ }^{130}$ See Shuttlesworth v. City of Birmingham, 394 U.S. 147, 155 (1969) (finding obstructive use of permit requirement for public demonstrations unconstitutional); Cox v. Louisiana, 379 U.S. 536, 574 (1965) (holding that fair warning as to where a protest could take place is mandated by the First Amendment).

${ }^{131}$ See Papachristou v. City of Jacksonville, 405 U.S. 156, 171 (1972) (striking down an ordinance that allowed vagrancy convictions where racially mixed individuals rode together in a car).

${ }^{132}$ See Pickering v. Bd. of Educ., 391 U.S. 563, 574 (1968) ("[A] teacher's exercise of his right to speak on issues of public importance may not furnish the basis for his dismissal from public employment.").

${ }^{133}$ See Healy v. James, 408 U.S. 169, 194 (1972) (holding that a group which may have a philosophy of disruption and violence must be allowed access to university student group resources if it is found willing to obey reasonable campus rules and regulations); Gay Students Org. of the Univ. of N.H. v. Bonner, 509 F.2d 652, 663 (1st Cir. 1974) (holding that a state university cannot ban a group's social activities where they do not disrupt the work and discipline of the school). 
officials. Federal and state appellate court judges enthusiastically carried out the program.

The effect of the Supreme Court's decisions is impossible to calibrate exactly, but it surely contributed to mass mobilization (as well as vice versa). On the one hand, the expression-protective program significantly lowered one of the bars to mass mobilization against state discrimination. Many ordinary people would have been less likely to join in an assurance game if they thought they would go to jail for participating in its activities. The availability of federal courts as a remedy made state censorship and obstruction less likely in 1961 than it had been in 1951 - and vastly less likely in 1971 than it had been in 1961 . On the other hand, when the state did clamp down on protest movements, the foregoing jurisprudence gave the protesters good arguments to persuade uncommitted observers that it was the state, and not the protesters, that was behaving lawlessly.

This brings us to a critical point. For all of the IBSMs, there were important showdowns between the state enforcing the status quo and minorities objecting to it. Confrontational and seemingly arbitrary enforcements of discriminatory laws quickened the transition of nascent social movements into mass movements.

The revolutionary idea that women should have access to birth control materials became the foundation of a social movement as a result of a series of well-publicized clashes between the government and Margaret Sanger. Her federal indictment in 1914 for violating the Comstock Act drove her into self-imposed exile for a year, but she returned to New York as a heroine whom the federal prosecutors dared not prosecute. When they dropped the indictment in 1916, Sanger was a "celebrity." 134 Perhaps perceiving what tonic government prosecution was for a social movement, Sanger thereupon opened a birth control clinic in New York, dispensing materials that were illegal under state law. The state arrested her and tried her in early 1917. Sanger's trial and $\mathbf{3 0}$ days in jail were a public sensation that attracted thousands of people to her cause. ${ }^{135}$ In a pièce de résistance, city po-

${ }^{134}$ GaRROW, LiBERTY AND SEXUALITY, supra note 13, at 11; see CHESLER, supra note 13, at 126-40 (describing Sanger's personal struggles during the time of her emergence as a celebrity); DAVID M. KENNEDY, BIRTH CONTROL IN AMERICA: THE CAREER OF MARGARET SANGER 72-73 (1970) (describing husband William Sanger's arrest and trial for the distribution of his wife's birth control pamphlets, a government action aimed at flushing Margaret Sanger from hiding); SANGER, supra note 117, at 176-89 (containing Margaret Sanger's description of the arrest and trial of her husband, and of how prosecutors sought to use this trial to coerce her into pleading guilty).

${ }^{195}$ See CHESLER, supra note 13, at 152-58 (chronicling Sanger's trial and the events 
lice disrupted the first national birth control conference, held in November 1921. With every move reported by the press, the officers removed a speaker from the stage and arrested Sanger, to universal disapproval. Thanks to this incident, "the outlook for the birth control movement [became] brighter than it ever was." the American Birth Control League-the parent of Planned Parenthood-and the mass social movement had commenced.

The civil rights movement presents an even more dramatic example. After a decade of bus boycotts, sit-ins, and sloth-like desegregation, the SCLC in 1963 targeted Birmingham as the object of its concentrated efforts. The goals of the campaign were to desegregate public facilities, to establish fair hiring procedures for the city's businesses, to free activists who had been arrested for their protest activities, to reopen public parks and playgrounds the city had closed rather than comply with a court order for integration, and to appoint a biracial commission to advance school desegregation. ${ }^{197}$ The campaign involved a boycott of all segregated businesses and repeated demonstrations and marches. While it was the boycott that brought business leaders around, the demonstrations yielded the moments that galvanized people of conscience everywhere: Commissioner Eugene "Bull" Connor's turning firehoses and attack dogs onto black children protesting their exclusion; Dr. King's and Reverend Shuttlesworth's arrests for violating a state court injunction against protest marches, which begat Dr. King's famous Letter from a Birmingham Jail; and near riots after a series of racist bombings, which the ministers and other leaders quelled in personal appeals through the night. All of these events received worldwide publicity. Business leaders capitulated, over the objections of Connor, who soon thereafter lost his office to a more moderate segregationist. Changes in Birmingham were just the first of the boycott's effects. In the ten weeks after the SCLC's victory in May 1963, at least 758 demonstrations occurred in 186 cities across the South, with 14,733 people arrested. ${ }^{138}$ Within six months of

leading up to it); SANGER, supra note 117, at 224-37 (explaining which phrases and actions became pivotal at trial).

${ }^{1315}$ Birth Control and Taboo, Editorial, THE NEw REPUBL.LC, Nov. 30, 1921, at 9; see CHESLER, supra note 13, at 200-05 (discussing the birth control movement's broadening base of support); SANGER, supra note 117, at 301-15 (describing the increasingly difficult task of opposing the birth control movement).

${ }^{1: 37}$ MORRIS, supra note 12, at 250-51. For accounts of the campaign from beginning to end, see id. at 250-74; and GARROW, BEARING THE CROSs, supra note 12, at 23164.

138 Thomas R. Brooks, Walls Come Tumbling Down: A History of the Civil 
the Birmingham capitulation, Dr. King had engineered a March on Washington that established the civil rights movement as a powerful national force. ${ }^{139}$ A year after the march, President Lyndon Johnson signed the Civil Rights Act of 1964. SCLC's campaign became a mass social movement in 1963 and 1964, and the law was a critical backdrop for that transition. ${ }^{140}$

A galvanizing moment for the pro-choice movement arose out of the case of Sherri Finkbine. ${ }^{141}$ She was pregnant with her fifth child in 1962, when she discovered that Thalidomide, a drug she had been taking, was believed to cause severe birth defects. Finkbine consulted a doctor, who recommended an abortion and assured her that a local hospital would okay the procedure as a "therapeutic" abortion allowed by state law. On the eve of the scheduled procedure, a local newspaper publicized her decision, and the story was picked up nationally. The story was sensational because an abortion to avoid having a child with birth defects tested the boundaries of prevailing abortion law. A strict construction of the therapeutic abortion allowance would require that the mother's life or physical health be endangered by the pregnancy, which was not the case with Finkbine, while a liberal construction would allow the abortion, perhaps for the mental health of the mother. Once there was publicity, the hospital cancelled the procedure, and Finkbine, her husband, and her physician sued for a court order. ${ }^{142}$ According to historian Kristin Luker, "with the Finkbine case, what had been a trickle of public interest in the issue of abortion became a torrent" ${ }^{143}$ contributing to California's liberalization law in 1967, which in turn was followed by the creation of the prochoice stance as a branch of the women's movement. ${ }^{144}$

\footnotetext{
RIGHTS MOVEMENT 1940-1970, at 210 (1974).

${ }^{139}$ See GarRow, BEARING THE CROSS, supra note 12, at 277-86 (discussing some of the events which motivated the March on Washington).

${ }^{140}$ The Montgomery and Birmingham boycotts reflected the transition from a prisoner's dilemma for people of color-resulting in few people participating-to an assurance game in which everyone wants to participate if others do as well. $C f$. Michael J. Klarman, Civil Rights Law: Who Made It and How Much Did It Matter?, 83 GEO. L.J. 433, 453-54 (1994) (documenting the utility of these confrontations in changing public opinion outside the state).

${ }^{141}$ For a detailed discussion of the case of Sherri Finkbine, see LukER, supra note 13 , at $62-65$.

${ }^{142}$ Finkbine ultimately had the abortion in Sweden. Id. at 64.

${ }^{143}$ Id. at 65.

${ }^{144}$ See generally id. at 66-125 (discussing the political struggles preceding both California's liberalized abortion law and the creation of the pro-choice movement). An additional impetus for California's liberalization came in 1966, when the head of the
} 
For the women's movement generally, the critical encounter was less dramatic than for the others. Title VII of the Civil Rights Act of 1964 prohibited workplace discrimination based on sex as well as race. The amendment adding "sex" to the title was regarded as a lark, and early enforcement of the sex discrimination bar was lackluster. ${ }^{145}$ Nonetheless, women filed one-third of the employment discrimination complaints received by the EEOC in the early years of the statute's operation. ${ }^{14 i}$ Feminists objected to the EEOC's policy and soon had a public forum for their objections. At the Third National Conference of Commissions on the Status of Women, criticisms of state as well as federal enforcement of sex discrimination laws were voiced, and a resolution was offered to insist on more vigorous enforcement. The conference organizers ruled the resolution out of order, inflaming feminists. Led by Betty Friedan, the famous author of The Feminine Mystique, twenty-eight women founded the National Organization for Women on June 26,1966 , the last day of the conference. ${ }^{147}$ As Friedan recalls, "it only took a few of us to get together to ignite the spark" that grassroots feminist consciousness raising and thinking had already created-"and it spread like a nuclear chain-reaction." 148

Like the civil rights movement, the gay rights movement offers several dramatic showdowns. ${ }^{14: 1}$ The most famous started on the night after Judy Garland died, June 27, 1969. ${ }^{150}$ The Stonewall Inn, a queer people's hangout in New York City's Greenwich Village, was periodically raided by the police, especially when the Inn's mob-linked owners failed to make their payments to the local authorities. Such raids were typically demeaning for the customers, whom officers of the law

California State Board of Medical Examiners said he would "get" any doctor who performed an abortion for a woman afflicted with rubella. This had the effect of solidifying physician support for a liberalized abortion law. Id. at 86-87.

${ }_{145}$ See Hugh Davis Graham, The Civil. Rights ERa: Origins and Development OF NATIONAL POLICY, 1960-1977, at 136-39 (1990) (describing the origins of the sex discrimination addition to Title VII); $i d$. at 211-32 (explaining the EEOC's ambivalent enforcement of the sex discrimination prohibition).

14i RHODE, supra note 13 , at 58.

${ }^{147}$ Caroline Bird, Born Female: The High COST OF KEEPING WoMEN DOWN 209 (rev. ed. 1970); Freeman, supra note 13, at 798-99.

${ }^{148}$ JUDITH HOLE \& ELLEN LEVINE, REBIRTH OF FEMINISM 81 (1971) (quoting Betty Friedan, N.O.W.-How It Began, WOMEN SPEAKING, Apr. 1967, at 4).

${ }^{149}$ For accounts of a January 1, 1965, confrontation between police and a gayfriendly society in San Francisco, see EDWARD ALWOOD, STRAIGH' Nliws: GAYS, Lesbians, AND THE NEwS MEdia 40 (1996) and SuSAN STRYker \& Jim VAN BuSkIRK, GAY BY THE BAY: A History of QueEr Culture in THE SAN Francisco Bay AREA $41-42$ (1996).

MARTIN DUBERMAN, STONEWALL 190-91 (1993). 
routinely threatened, physically assaulted, and humiliated. On the night of June 27, a few of the denizens fought back, assaulting the officers with punches, coins, and bottles. What started as a routine police harassment of "fags and dykes" became a police rout. Not only was the motley assortment of customers aroused to unaccustomed acts of resistance, but the entire community seemed to be. For the next several nights, thousands of queer people demonstrated and rioted in Greenwich Village. Although their havoc was relegated to a few paragraphs deep within the stately New York Times, the Village Voice covered it extensively, and word of mouth made Stonewall a national sensation. ${ }^{151}$ Literally overnight, the riots transformed a homophile movement of several hundred earnest homosexuals into a gay liberation movement populated by tens of thousands of lesbians, gay men, and bisexuals who formed hundreds of new organizations demanding radical changes in the way gay people are treated by the state. ${ }^{152}$

A final example recalls the origins of disability as a mass social movement. People with disabilities as well as federal administrators worked for enactment of the Rehabilitation Act, which included a broad anti-discrimination provision drafted and inserted by friendly staffers. They were stunned when President Nixon pocket-vetoed the law in 1972, and supporters demonstrated against Nixon's veto. ${ }^{153}$ In 1973, activists demonstrated in favor of the Rehabilitation Act and created a new organization for disability rights at a PCEH workshop session. ${ }^{154}$ Nixon signed the Rehabilitation Act into law in 1973. The new American Coalition of Citizens with Disabilities (ACCD) then conducted a grassroots protest and an inside-the-Beltway lobbying campaign between 1975 and 1977 to press HEW into adopting broad regulations to implement section $504 .^{1.55}$

These angry encounters with government law enforcers both galvanized and defined the birth control, civil rights, pro-choice,

${ }^{151}$ See Lucian Truscott IV, Gay Power Comes to Sheridan Square, Village Voice (New York), July 3, 1969, at 1 (describing the Stonewall riots); Dick Leitsch, First Gay Riot, ADVOCATE (Baton Rouge, La.), Sept. 1969 (describing the chain-reaction response to Stonewall).

${ }^{152}$ For a collection of homosexual experiences and struggles with the gay liberation movement, see OUT OF THE ClosETs (Karla Jay \& Allen Young eds., 1972).

${ }^{153}$ FLEISCHER \& ZAMES, supra note 15, at 49.

${ }^{154}$ For a discussion on how the American Coalition of Citizens with Disabilities linked both local and particular disability associations into a national organization that was at the center of future campaigns for laws protecting people with disabilities against discrimination, SCOTCH, supra note 15 , at $82-86$.

${ }^{155}$ FleISCHER \& ZAMES, supra note 15, at 52-53; SCOTCH, supra note 15 , at 55-57. 
women's rights, gay liberation, and disability rights movements. And they were encounters thoroughly immersed in law. The events played out in legal buildings-courthouses, city halls, police stations, and jails-and intimately involved legal actors-judges, legislators, police officers, governors, and presidents. The episodes were part of an ongoing drama in which legal actors were the villains but law and constitutional rights were the common language of the participants and the object of the conflict. Bull Connor surrounded his infamy with the shrouds of law-but it was a corrupt law disobeyed in the name of the Constitution as well as in the name of God. One powerful consequence of the events in Birmingham in May, 1963, was a sea change in public sentiment, as many people were persuaded that the freedom marchers' dignified understanding of the Equal Protection Clause must trump the attack dogs and fire hoses of apartheid. ${ }^{156}$ Margaret Sanger, Sherri Finkbine and other women seeking abortions of unwanted pregnancies, Betty Friedan and the other dissenters at the discrimination conference, the customers at Stonewall, and the disabled people protesting Nixon's vetoes were less dramatic players of the political theater that Bull Connor and Martin Luther King perfected.

All of these episodes were group mobilization moments, where representatives of the old status regime took a firm position against identitybased protesters insisting on a new normative regime-but with disastrous consequences for the old regime.

${ }^{156 i}$ Klarman, supra note 107 , at 11. 


\title{
Diagram 1
}

\section{Mobilization Moments}

\author{
Ordinary people who happen to be stigmatized minorities \\ petition for relief from unfair state discrimination against them \\ $\Downarrow$ \\ Public officials reaffirm strict (draconian) enforcement of \\ the old status regime \\ $\Downarrow$ \\ Protesters refuse to back down, insist on their equality \\ rights, place their bodies on the line; \\ media interest in the confrontation \\ $\Downarrow$ \\ Public officials overreact; media portrays them as brutes; \\ public sympathy for minority victims \\ $\Downarrow$ \\ Thousands of minority group members (and allies) \\ become active in what becomes a mass social movement
}

Bruce Ackerman talks of constitutional moments, where one branch of government committed to an old regime backs down when confronted with other branches that are backed up by public sentiment. ${ }^{157}$ In contrast, group mobilization moments involve clashes between state law enforcers and minority citizens, where the main effect is not the backing down of the law enforcers (though that might happen) but is instead the instigating of thousands of previously quiescent minority citizens to oppose the law's discriminations.

\section{DESCRIPTIVE MODEL: LAW AND THE INSTITUTIONALIZATION OF IDENTITY-BASED SOCIAL MOVEMENTS}

IBSMs spawned by law have also been sustained by law. Most mass mobilizations have flickered across history like comets falling in the sky. They have left marks, but transient ones. A feature of the IBSMs of the twentieth century is that they did not burn out; their fires have raged for decades. This was possible because of the institutionalization of the political energy of those movements. Institutionalization was possible in large part because of the legal system, which required a long-term effort to change the discriminations that were a target of

1571 Bruce ACkerman, We The People: Foundations 59-60 (1990). 
the social movements, and then offered the possibility of the state as an ally in achieving the social goals of the movement. In short, the pas de deux between the state and the IBSM helped, to perpetuate the latter. Another feature that ensured the perpetuation of these social movements was the inevitability of countermovements, themselves petitioning the state to preserve old rules that the IBSMs considered discriminatory but that traditionalists considered morally sound.

Eliminating oppressive law is originally the goal of an IBSM, so most legal actors are adversaries in the movement's early stages. If the social movement endures, its objectives shift toward obtaining helpful laws, rather than just nullifying bad laws. Legal actors become potential allies, even partners in the movement. Legal actors were important partners in the disability rights movement even during its incipiency. Indeed, once a countermovement arises, there is a competition for the attention and loyalty of legal actors. For judges, the competition is for the generation of constitutional discourse and statutory interpretations favorable to one's group. And a feature long-obscured in the movement's history becomes clear: even when law is the enemy, and even more when law becomes a potential ally, law channels not just the strategies of IBSMs and their countermovements but their discourses as well. As law channels the movements' discourses, law changes those discourses, and those movements.

\section{A. Incremental Legal Remediation and the Institutionalization of Identity-Based Social Movements}

Once thousands or even millions of people were mobilized on behalf of an IBSM, existing institutions enlisted them, and new institutions were formed. Because the meta-goal of each movement was to change people's attitudes about the minority, it is easily imaginable that the activists and their organizations would engage in moral suasion, educate the public, and work to cultivate subcultural mores and institutions. And so they did. But each movement learned soon enough what its members suspected from their bitter personal experiences: that people do not change their attitudes, and especially their prejudices, overnight. Because the minority's identifying trait was also the object of pervasive legal stigma, these social movements also sought to change the letter and application of the law. Some legal change was easier to accomplish, and the results were tangible. But it took a long time, and headway was made step by step, at best. The length of the process of legal reform required that the movement develop institutions for long-term political action, and thereby ensured 
the longevity of the movement.

Once a minority group had organized itself as an ongoing institutional force in politics, it was able to move the law and bend the political process to be friendlier to the minority, no matter how traditionally despised. As before, the minority was savvy, targeting the most vulnerable and outdated public discriminations and seeking redress from the level of government (federal/state/local) and the organ of government (legislature/agency/court) most likely to give it. For example, lesbians and gay men had most of their early successes at the local and state level; once thousands came out of their closets, they appeared, overnight, as an important voting block in the big cities to which so many of them had gravitated. Their initial target was laws criminalizing consensual sodomy, measures to which legal elites were already hostile and against which Americans' libertarian impulses and the Supreme Court's privacy jurisprudence could be mobilized. Before Stonewall, forty-nine states criminalized consensual sodomy, most penalizing it as a serious felony. By 1981, twenty-six states had abrogated their consensual sodomy laws, either by legislative repeal or judicial invalidation, and another eleven had reduced consensual sodomy to a misdemeanor. ${ }^{158}$ Each state repeal was heralded by the new gay press and provided encouragement for the next repeal effort. Lesbian and gay groups and their allies (like the ACLU) also went to court to nullify or curtail other laws penalizing them; courts were willing to trim back or override laws criminalizing lewd solicitation, congregation of gay people, vagrancy, and cross-dressing.

Once gay people were no longer presumptive criminals, they sought legal recognition of a new status as equal citizens. In urban centers, gay/lesbian/bisexual/transsexual ("GLBT") groups were often successful in procuring laws prohibiting private as well as public discrimination on the basis of sexual or gender orientation. ${ }^{160}$ Wis-

${ }^{158}$ The states that abrogated their consensual sodomy laws were Alaska (1978), California (1975), Colorado (1971), Connecticut (1969), Delaware (1972), Florida (1974), Hawaii (1972), Idaho (1971), Illinois (1961), Indiana (1976), Iowa (1976), Maine (1975), Nebraska (1977), New Hampshire (1973), New Jersey (1978), New Mexico (1975), New York (1980), North Dakota (1973), Ohio (1972), Oregon (1971), Pennsylvania (1980), South Dakota (1976), Vermont (1977), Washington (1975), West Virginia (1976), and Wyoming (1977). ESKRIDGE, GAYLAW, supra note 14, at app. A1. Consensual sodomy was reduced to a misdemeanor in Alabama (1977), Arizona (1977), Arkansas (1977), Kansas (1969), Kentucky (1974), Minnesota (1977), Missouri (1977), Nevada (1977), Texas (1973), Utah (1973), and Wisconsin (1977). Id. laws).

${ }^{159}$ See id. at 108-11 (discussing state and federal cases refusing to enforce such ${ }_{160}$ See, e.g., id. at 125-41, 205-38, app. B2 (surveying state and municipal anti- 
consin was the first state to prohibit private discrimination on the basis of sexual orientation, and other states have followed. ${ }^{161}$ As before, each new ordinance or law was heralded by the gay media and inspired further efforts and initiatives, including proposed federal legislation. ${ }^{162}$ Success in baby steps at the local level was a spur to the social movement, both by demonstrating to still-closeted gay people that the movement could be successful and by illustrating how far gay people had to go to achieve full legal equality.

Even though each one of these legal success stories had little discernible effect on the life of the average lesbian or gay man, they had a cumulative effect on people's lives and contributed to the perseverance of gay liberation as a social movement. Stonewall triggered thousands of coming-out stories and hundreds of organizations but did not guarantee that this social movement could be sustained. (Most of the post-Stonewall organizations, in fact, expired within two years.) In order for a social movement to last, new waves of lesbians or gay men had to edge out of their closets and get involved in an association that could organize their contributions. The more participants and the more success stories, the more likely it was that the gay person at the closet door would join the assurance game. No one wanted to be part of a quixotic social movement; a lot of gay people liked being just a little bit ahead of their time, in a social movement inching toward success. ${ }^{163}$

The gay and lesbian rights experience can be generalized to other

discrimination laws).

${ }^{161}$ States that adopted laws prohibiting discrimination by private employers are California (1979 (by court decision)), Connecticut (1991), Hawaii (1991), Massachusetts (1989), Minnesota (1993), Nevada (1999), New Hampshire (1997), New Jersey (1991), Rhode Island (1995), Vermont (1991), and Wisconsin (1982). Id. at app. B2. A number of other states, starting with Pennsylvania in 1975, bar sexual orientation discrimination in state employment. See id. (listing the states). Maryland adopted legislation in 2001 barring private as well as public discrimination on the basis of sexual orientations.

${ }^{162}$ Although bills prohibiting private discrimination on the basis of sexual orientation were introduced in Congress as early as 1974, none received the benefit of congressional hearings until 1983, and none reached the floor of either chamber until 1996.

${ }^{163}$ See BRIAN BARRY, SOCIOLOGISTS, ECONOMISTS AND DEMOCRACY 30 (1978) ("[M]ore enthusiasm for [a movement's] pursuit is likely to be elicited if it looks as if it has a chance of succeeding than if it appears to be a forlorn hope."); CHONG, supra note 126, at 90-102 (explaining how the social and psychological benefits of participation are contingent upon the success of the movement); George Klosko, The Principle of Faimess and Political Obligation, 97 ETHICS 353, 358 (1987) (arguing that one makes social contributions only to the extent to which one sees other individuals making similar sacrifices). 
social movements. The ongoing sustainability of an IBSM has been tied to its ability to generate a series of successful efforts to reform the law, but with each success leaving room for further progress. Anecdotal evidence of changed attitudes ("I came out to my Mother, and she said: 'I used to fear you people but now realize that gay is great!") will not suffice unless widely experienced and reported. Wellpublicized evidence of legal victories, even little ones, serves this goal admirably. Ironically, therefore, the legal discrimination that was an original impetus for the social movement can in its bit-by-bit demise provide fuel for sustaining the movement. Correspondingly, gay liberation inexorably transmuted into a gay rights movement, as it devoted an increasing amount of resources to its campaigns to change the law, through litigation, legislation, administration, or some combination.

In contrast to gays, blacks worked disproportionately at the national level, because local politics was so biased against them in the southern states where they were most disadvantaged. ${ }^{164}$ Blacks also worked disproportionately in courts, because judges had the values and the political independence needed to shift the burden of inertia from apartheid policies to nondiscriminatory ones. The strategy paid off with momentous changes in national law and policy: desegregation of the armed forces, termination of sit-at-the-back-of-the-bus policies and of apartheid in Brown and its progeny, the Civil Rights Act's prohibition of race discrimination by private employers and public accommodations as well as by state and federal governments (as amended in 1972), the Voting Rights Act's assurance of the right to vote, and the Fair Housing Act's ban on discrimination in renting and home sales. ${ }^{165}$ These developments at the national level erased the de jure discriminations at the state level. As a result, the civil rights movement was uniquely successful in purging American law of almost all of its invidious race-based classifications. But that was only the beginning.

The gay rights and civil rights movements illustrate the tendency of IBSM law-reform institutions to become self-sustaining. Even after

${ }^{164}$ Even though the SCLC's local boycotts and sit-ins were key to transforming civil rights into a mass mobilization between 1955 and 1963, after 1963 the SCLC, like other civil rights groups, concentrated on federal legislative and administrative efforts.

${ }^{165}$ See GRAHAM, supra note 145 , at $177-204$ (providing a detailed survey of federal civil rights laws and executive orders, as well as their early enforcement); see also ALFRED W. BlumROSEN, BLACK EMPLOYMENT AND THE LAW 51-101 (1971) (discussing federal equal employment opportunity laws and their early effectiveness). 
the long struggle to nullify or repeal openly discriminatory laws is won, struggles against the discriminatory application of facially neutral laws continue. The struggle against discrimination by the state must be never-ending, so long as some law enforcers harbor prejudice or stereotypes regarding the minority. Additionally, institutions will seek the state's aid against private discrimination and violence. That effort requires legislation and then similar problems of enforcement. Finally, the minority will sometimes ask for state subsidies or rules that seek to remedy the effects of past discrimination.

\section{Diagram 2 \\ The Ongoing Law Reform Campaign Against Discrimination}

[1] Repeal or nullification of laws that openly discriminate against the minority $\Rightarrow$ Struggle over implementation group

$\Downarrow$

[2] Expansion of the duty of fairness to private employers, public accommodations, $\Rightarrow$ Struggle over implementation private persons

[3] State remedial subsidies or protections

benefiting the minority group members

The disability and women's rights movements fit the pattern described by Diagram 2. ${ }^{166 ;}$

${ }^{166}$ [1] Between 1930 and 1970, disabled people were able to repeal many laws that discriminated against them. [2] The Rehabilitation Act of 1973 was an important milestone, sealed by vigorous lobbying by disability rights groups to procure aggressive regulations. See SCOTCH, supra note 15 , at $82-120$ (providing a detailed account of HEW regulations concerning disability rights); see also STEPHEN L. PERCY, DISABILITY, Civil Rigites, And Public Policy: The Politics of Implementation 64-82 (1989) (discussing the implementation of the Rehabilitation Act of 1973). [3] Their legal efforts culminated in the Americans with Disabilities Act of 1990, which imposes broad nondiscrimination obligations on private and federal entities and requires reasonable accommodations for the disabled as well. See generally COLKER, supra note 51 (detailing the legislation, regulations, and case law thereunder).

Likewise, [1] women's groups first sought repeal of "protective" as well as exclusionary legislation precluding them from equal opportunities between 1930 and 1970; the proposed ERA would have swept most of these away, but they were repealed or judicially invalidated beforehand. [2] Title VII, amended to include pregnancy-based discrimination, the Equal Pay Act of 1963, Title IX, and other legislation between 1963 and 1994 imposed extensive nondiscrimination obligations on private as well as public entities. [3] Finally, firms and government bodies adopted a range of affirmative ac- 
Although it fits the pattern of Diagram 2, the pro-choice movement presents interesting variations. The Supreme Court in Roe $v$. Wade invalidated all existing abortion statutes, comparable to stage one in Diagram 2. If states had simply left abortion deregulated after Roe, the pro-choice movement might have waned, because the Supreme Court's decision would have given activists the complete relief their movement was then seeking. Indeed, there was a fall-off of intensity in the pro-choice movement after Roe. ${ }^{167}$ But like Brown, Roe created a lengthy dialogue between federal courts and state legislatures as to the limits of the state's duties under the new regime. Just as the Supreme Court left Brown not fully enforced (from the point of view of the "winners"), so the Supreme Court has left Roe not fully enforced (from the point of view of the "winners"). Even when reaffirming Roe as a precedent, the Court has permitted the state to burden the right to choose an abortion with many procedural and some substantive hurdles-essentially allowing a fair amount of state variation as to policy and therefore opening up intense political contests at the state level between the pro-choice movement and traditionalists. ${ }^{168}$

Stage two in Diagram 2 looks somewhat different for the prochoice movement. Private discrimination against a woman because she has had an abortion-at least in the workplace and in public accommodations-has not been documented as an important problem. ${ }^{169}$ Hence, the pro-choice movement has not sought omnibus anti-discrimination laws, as have the women's rights, civil rights, gay rights, and disability rights movements. But it has sought public intervention to head off private disruption of abortion clinics. Operation Rescue and other pro-life groups have picketed abortion clinics, lobbied women to change their minds, and sometimes engaged in violence or assaults against women seeking abortions or their health pro-

tion, maternity leave, and other remedial policies in the $1980 \mathrm{~s}$ and $1990 \mathrm{~s}$. The best introduction to the statutes, regulations, and case law is BARBARA ALLEN BABCOCK ET al., Sex Discrimination and The Law: History, Practice, and Theory (2d ed. 1996). For a shorter treatment, see RHODE, supra note 13, at 111-304.

${ }_{167}$ See STAGGENBORG, supra note 13, at 57-65 (discussing how strategies and tactics narrowed after January 22, 1973).

${ }^{108}$ See Planned Parenthood v. Casey, 505 U.S. 833, 869-901 (1992) (reaffirming Roe but re-articulating its rule to allow significant state regulation of the decision to abort).

${ }^{169}$ Better documented has been the obverse: employers frequently discriminate against women who are pregnant, especially if the woman is not married. The employer typically does not even know when an unmarried employee terminates her pregnancy with an abortion, but of course does find out about the pregnancy if carried to term. 
viders. ${ }^{170}$ Pro-choice groups have engaged in an ongoing effort to protect clinics against what they consider illegal harassment, and these disputes have often ended up in court to determine how much space for this kind of dissent and persuasion the Speech Clause requires. ${ }^{171}$ Stage three is the pro-choice movement's ongoing struggle to persuade federal and state medical insurance and welfare programs to subsidize or pay for abortions, particularly for women who cannot afford them. This struggle has not been notably successful. ${ }^{172}$

As Diagram 2 suggests, IBSM organizations that work for changes in the law or law enforcement always have an agenda that could keep them busy-and that is beneficial to minority group members who can be expected to support the organizations with varying degrees of enthusiasm (depending on the operation of the various collective action difficulties). The punchline is that an IBSM's legal organizations have had a durability that its community activist counterparts have not. For example, the Inc. Fund and the SCLC both preceded and long outlasted SNCC; Planned Parenthood, NARAL, and the National Organization for Women (NOW) have achieved a national status that counseling and community-support groups have not; Lambda Legal Defense \& Education Fund and the Gay and Lesbian Advocates and Defenders of Boston have eclipsed the hundreds of radical queer groups that spontaneously formed in the wake of Stonewall and disappeared almost as quickly.

This organizational sociology suggests, further, that lawyers have played a disproportionate and increasing role in IBSMs. For example, the period after Stonewall saw gay activists of all sorts-artists, hippies, drag performers, shopkeepers, students, writers-participate as initiators and spokespersons, but most of them failed to sustain a leader-

${ }^{170}$ See Faye Ginsburg, Rescuing the Nation: Operation Rescue and the Rise of AntiAbortion Militance, in ABORTION WARS, supra note 13, at 227-50 (tracing the rise and decline of Operation Rescue from 1988 to 1993); Victoria Johnson, The Strategic Determinants of a Countermovement: The Emergence and Impact of Operation Rescue Blockades, in WAVES OF PROTEST, supra note 8, at 241, 245-65 (describing Operation Rescue and its tactical interactions aimed at deterring abortions); see also RANDALL A. TERRY, OPERATION RESCUE (1988) (explicating the activist pro-life philosophy underlying Operation Rescue).

${ }^{171}$ See Madsen v. Women's Health Ctr., Inc., 512 U.S. 753, 776 (1994) (upholding those parts of an injunction against abortion clinic protesters that do not unnecessarily burden free speech); Schenck v. Pro-Choice Network of W.N.Y., 519 U.S. 357, 374 (1997) (following and applying Madsen).

${ }^{172}$ See Harris v. McRae, 448 U.S. 297, 316 (1980) (allowing the federal government to exclude abortions from funded medical services); Maher v. Rose, 432 U.S. 464, 479 (1977) (giving a similar account for state-funded medical services). 
ship role for long. The leaders who persevered, like Tom Stoddard and Nan Hunter, were often lawyers or paralegals like the famous Frank Kameny. Generally speaking, a social movement seeking to overturn a melange of antigay state rules and practices requires the assistance of lawyers, but once the lawyers get involved, legal reform comes to dominate other kinds of action more than before, and the movement as a whole tends to assume an increasingly lawyerly aura. This has consequences for the social movement: formal equality has dominated other goals of the movement, because lawyers feast on formalisms; the movement has tended toward assimilationist and reformist rather than separatist and radical stances, because lawyers cannot defend the latter before judges and legislators who are their audience; and members of the minority who are least like the mainstream American have tended to be left behind.

\section{B. The Life Cycle of an IBSM: From a Politics of Protection to Culture Clashes to Normal Politics}

IBSMs seek to change law and law enforcement not just for prudential reasons but also for idealistic ones. The social movement arises as a response to law's stigmatization of its members based upon their malign variation from the norm. So long as members of the minority group accept their inferiority, there can be no social movement. Once some group members come to believe-and then organize together to insist-that their trait is a tolerable or even a benign variation from the norm, there is the possibility of a social movement. ${ }^{173}$ If an IBSM does form and achieve any successes, a countermovement will arise, however, because others in society will not only continue to accept the old norm but will also continue to bind up their own identities in it. Thus, traditionalist countermovements-the states' rights movement of the 1950s, the anti-ERA and pro-life movements of the 1970s, and the traditional family values movement of the 1970 s-are themselves identity-based mirror images of the social movements to which they are responding.

Like the social movements that trigger them, countermovements develop in predictable ways. ${ }^{174}$ While many of their members continue

${ }^{173}$ A tolerable variation is one that is not as "good" as the norm but is not so "bad" that it cannot be safely allowed. A benign variation is one that is normatively indistinguishable from the mean or median.

${ }^{174}$ See Tahi L. Mottl, The Analysis of Countermovements, 27 SOC. PROBS, 620, 620 (1980) (providing a sociological analysis of countermovements). 
to insist that the minority's trait is malign, that position becomes less tenable once the original social movement has taken off. Hence, the countermovement's politics of preservation tends to be an effort to hold the line at tolerable variation: the state should not deprive people of important freedoms because of their degraded traits, but tolerance does not require the state to "promote" social deviance at the expense of traditional values or institutional practices. Arguments for legal segregation give way to "no promo" arguments. People of color should no longer be segregated from white people, but the state should not promote integration at the expense of private choice and localism. Women ought not be barred from jobs, but the state should not promote a full equality that would undermine the family. The state may tolerate some family planning but ought not promote abortion. Gay people ought not be imprisoned but neither should the state promote homosexuality. The contest between the ongoing politics of recognition and the responsive politics of preservation is a clash over essentially cultural issues fought on the battleground of politics. If the clash is resolved in favor of treating the minority's variation as benign, then the minority group will join the normal political process by which state entitlements and benefits are apportioned to salient interest groups in society. This normal political process entails a politics of redistribution discussed earlier.

This is the life cycle of an IBSM in a nutshell. Consider it in greater detail.

\section{From a Politics of Protection to a Politics of Recognition}

During the pre-history of the IBSMs discussed in this Article, both mainstream society and most members of the minority group assumed the superiority of the trait that distinguished the majority from those who were "colored" or "retarded" or "inverted" or "degenerate." So long as there was this public consensus, there was not much politics surrounding the malign variation characterizing the minority. The status quo was a stable apartheid: physical segregation of racial minorities, confinement of women to the domestic sphere and homosexuals to the closet, and shunting off disabled people to hospitals.

If a significant portion of the mainstream ("traditionalists") became alarmed at threats seemingly posed by a socially visible and normatively threatening vanguard of the minority, however, the politics changed. Traditionalists would engage in a politics of fear, seeking to put down those of the minority whom they viewed as threats to the public order. Examples of this kind of politics were the creation of a 
terrorizing Jim Crow regime in the South, ${ }^{175}$ state and federal exclusions of Asian immigrants from the prerequisites of citizenship, ${ }^{176}$ the eugenics movement, ${ }^{177}$ the sexual purity campaigns in most American cities and then by state and federal officials, ${ }^{178}$ and the McCarthy era crusades against blacks, cross-dressers, and homosexuals. ${ }^{179}$ The politics of fear could crop up anytime, anywhere. Such a politics can be understood as a preemptive strike, a tool of those seeking to forestall or destroy incipient social movements by reaffirming the malignancy of trait variation and discouraging minorities from departing from their traditionally degraded social roles. (Recall that people can be discouraged from joining a social movement if the state makes the costs of activism high enough.) For most of the twentieth century, this politics was highly effective in preventing people of color, disabled persons, women, and gay people from mobilizing into social movements.

The people caught up in these terror campaigns sometimes tried to resist with any arguments they could muster. At some pointwhen some minority group members believed their trait was not a malignant variation-the politics of fear generated a responsive politics of protection. Most twentieth century gaylegal history was little more than an effort by homosexuals to keep themselves out of jail and to preserve pitifully marginal spaces for their socializing and informationsharing. The Mattachine Society of Los Angeles in the 1950s, for example, billed itself as one seeking to educate the public, but its most important activities involved protecting homosexuals from police tyr-

${ }^{175}$ See LiTWACK, supra note 38 (detailing day-to-day experiences of blacks living in the late-nineteenth- and early-twentieth-century South).

${ }^{176}$ See Korematsu v. United States, 323 U.S. 214, 233 (1944) (Murphy, J., dissenting) (documenting legal discriminations against Asians and Asian Americans in federal immigration law and in state property, family, and contract law); ANCHETA, supra note 12 , at 19-30 (offering a similar account).

${ }^{177}$ See KEVLES, supra note 30, at 251-68 (surveying the eugenics movement and its deployments of the law against people with disabilities).

${ }^{178}$ See ThOMAS MACkey, Red Lights OUT: A Legal History of Prostitution, DISORDERLY HOUSES, AND VICE DISTRICTS, 1870-1917, at 5-11 (1987) (exploring the legal community's response to anti-prostitution crusades); RoseN, supra note 25, at 1437 (discussing campaigns against the "social evil" of prostitution in the American Progressive Era); Leslie Fishbein, Harlot or Heroine? Changing Views of Prostitution, 18701920, 43 HISTORIAN 23, 28 (1980) (canvassing ideological approaches to solving the prostitution problem).

${ }^{179}$ See D'EMILIO, supra note 14, at 40-53 (discussing McCarthy era campaigns against homosexuals); ESKRIDGE, GAYLAW, supra note 14, at 57-95 (surveying the state and federal government's response to homosexuality in the public arena). 
anny. ${ }^{180}$ So long as homosexuals considered themselves inferior, as many of the early homophile leaders did, their normative plea was for nothing more than tolerance: don't put us in jail; we are no threat to you; let us live our lives in peace. The Mattachine Society of Washington (MSW), founded in 1961, announced a new politics for homosexuals. Going beyond the Los Angeles Society's apologetic politics of protection, the Washington Society insisted that the state treat gay people no differently than straight people. Frank Kameny, MSW's leader, sold his slogan, "Gay is Good," to the other homophile organizations in 1967. ${ }^{181}$ Once gay liberation took off after Stonewall, "Gay is Good" became the hallmark of this IBSM. The newly mobilized lesbian, gay, and bisexual groups insisted not only that antigay legal penalties be nullified or repealed but also that full legal equality be recognized: not only should the state not discriminate against gay people, but it should bar discrimination by private employers and public accommodations. Their idea was that the social disrespect shown to gay people was encouraged and fortified by the law, which, if transformed, could become an instrument for turning that disrespect into social tolerance. This was, and remains, an aspiration and not a reality for gay people.

In moving from a politics of protection to one of recognition, the gay rights movement followed the path taken by the civil rights and women's movements. The NAACP and other civil rights groups pioneered the politics of recognition. A key moment in that politics came in 1948-1950, when the NAACP Inc. Fund abandoned its strategy of challenging just the unequal funding of segregated schools and decided to challenge the system of public school segregation itself. ${ }^{182}$ The NAACP's argument was that even if black schools were every bit as good as white ones, black children still suffered intangible injurythe injury of stigma. ${ }^{183}$ The implicit argument was that this stigma violated the Equal Protection Clause because its harm to black children was not justified by any sound reason; race was a benign difference

${ }^{180}$ See D'EmILIO, supra note 14, at 70 (noting Mattachine's efforts to expose police entrapment practices targeted against homosexuals).

${ }^{181}$ See David K. Johnson, "Homosexual Citizens": Washington's Gay Community Confronts the Civil Service, WASH. HIST., Fall/Winter 1994-95, at 62 (examining the influence of Kameny on the Mattachine Society of Washington).

${ }^{142}$ KLUGER, supra note 12, at 294; TUSHNET, supra note 95 , at 114-15, 136-37. Before 1948, the Inc. Fund had argued that the actual operation of southern schools violated the separate-but-equal formula of Plessy.

${ }^{18: 3}$ See TUSHNET, supra note 95, at 115-36 (describing the success of the intangible injury argument against segregation). 
that ought to have no bearing on state policy. Brown of course adopted these arguments, and they became the premise of a generation's struggle to integrate southern schools, public facilities, and private accommodations and workplaces.

A similar shift occurred within the women's movement in the 1960s. Most women as well as men in the 1950s accepted the propositions that women were materially different from men, that women's most satisfying role was motherhood (and men's was supporting a family), and that abortion was morally questionable unless required by the physical health of the mother. Many women changed their minds during the 1960s; they came to conclude that any differences between the sexes were not material to women's equal participation in the workplace and in state activities and programs, and that abortion was a choice that a woman could morally make for the good of her family, her career, or her emotional well-being. ${ }^{184}$ With this explicit politics of recognition, NOW and NARAL replaced the NWP and Planned Parenthood as the locus of the women's movement. Their politics of recognition seemed triumphant when Congress sent the ERA to the states for ratification in 1972 and the Supreme Court decided Roe $v$. Wade in 1973.

\section{Culture Clash: The Politics of Recognition Meets a Counter-Politics of Preservation}

Once the civil rights movement won its public victory in Brown, there coalesced in the South a powerful countermovement, "massive resistance" against required integration. Like the civil rights movement, the countermovement operated through the mechanisms of law. Between 1955-1961, southern states adopted almost 200 statutes defying or seeking to evade Brown's mandate. ${ }^{185}$ This reaction was itself a kind of identity politics: Southerners viewed their disapproval of "mixing" the races as a normative as well as biological mandate. What set the Southerner apart from the Yankee as well as the "uppity" African American was his self-image as a man who respected tradition,

${ }^{184}$ See MANSBRIDGE, supra note 13, at 14, 216 (finding that by 1970, most women supported the ERA, with support strongest among women working outside the home); STAGGENBORG, supra note 13 , at 58 (discussing how women's opinions about abortion changed during the period of 1967-1973).

${ }^{185}$ Gary ORfield, THE Reconstruction of SOUTHERN Education: THE SCHOOIS AND THE 1964 CIVIL RIGHTS ACT 17-18 (1969); REED SARRATT, THE ORDEAL OF DESEGREGATION 363 (1966). 
honor, and (most of all) purity. ${ }^{186}$ Millions of Southerners were invested in this self-image, and the intensity of their reaction to Brown cannot be explained by mere economic self-interest. Theirs was the classic politics of preservation, and it was complex. Extremists in the movement defended the traditional position that any variation from whiteness was a degeneration, but the most astute defenders of apartheid realized that this defense was untenable outside the South-and that if the South were isolated on this issue all was lost. Without denying that racial variation was malignant, these "moderate" defenders of apartheid sought to shift the debate from the substantive morality of racism to the procedural morality of localism and states' rights. ${ }^{187}$ Notwithstanding these smarter arguments, the segregationists' politics of preservation suffered big setbacks when Congress enacted the Civil Rights and Voting Rights Acts in the mid-1960s.

The anti-ERA and pro-life countermovements followed the same pattern. Once women's politics of recognition actually seemed to be reallocating entitlements and changing the face of American law, traditionalists reconceptualized the status quo in identity-based terms. As they redefined it, one's identity as a mother or as a family-oriented humanitarian is implicated if the state encourages yuppie women to have careers by barring all traditional sex-based discriminations and even by allowing what they consider the "murder" of helpless fetuses. ${ }^{188}$ These were powerful identity-based images, and millions of women as well as men claimed them. The resulting politics of preservation was, like that of the massive resistance movement, complex. Radical traditionalists maintained that abortion was always malignant unless necessary to save the life of the mother and that the differences between the sexes was significant (but of course not "malignant," unless deployed in the wrong way), such that women's primary role was mother and wife in a traditional marriage. Pragmatists in the coun-

${ }^{180}$ See generally Hovenkamp, supra note 35, at 633-35 (arguing that segregation was ultimately based on the fear that interracial marriage and biracial children would weaken the white race).

${ }^{187}$ For an overview of the southern reaction to Brown, see ROSENBERG, supra note 107, at 78-85; WILKINSON, supra note 105, at 78-95; and Klarman, supra note 107, at 97 118, showing how the Broun decision catalyzed southern resistance to racial change. To see how southern judges used the rights rhetoric rather than openly racist rhetoric to avoid desegregating southern schools, see WILKINSON, supra note 105, at 80-84.

${ }^{188}$ See LUKER, supra note 13, at 126-57 (discussing the emergence of the pro-life movement); id. at 158-91 (comparing systematically different perspectives about gender roles, sexuality, and parenting held by pro-life versus pro-choice women); MANSBRIDGE, supra note 13, at 98-117 (comparing philosophical attitudes of pro-ERA versus anti-ERA women). 
termovement realized that these arguments would not stop the ERA or overturn Roe $v$. Wade, because they did not appeal to people in the middle. Thus, pragmatists sought to shift the debate from the substantive morality of sexism and abortion to the disruption the ERA and Roe entailed for the healthy husband-wife family ${ }^{18 ! 9}$ and the desirability of local regulation over federal judicial usurpation. ${ }^{190}$ Unlike the massive resisters, the pro-life and anti-ERA movements have scored significant successes in the national arena. The ERA was defeated and the Supreme Court has upheld the most deeply rooted sex discriminations and has allowed significant state regulation of abortion's decision-making process. ${ }^{191}$ Popular opinion remains ambivalent about women who abandon their traditional role as wife and mother.

Less well developed in the academic literature is what I call the "traditional family values" (TFV) countermovement. ${ }^{1.2}$ Once openly gay people emerged in the public culture in the late 1960s and early 1970s, many fundamentalist Christians made central to their faith an anti-homosexual reading of Leviticus $20: 13$ and Romans 1:26-27. ${ }^{199}$ Biblical literalism reasserted the value of male-female procreative sex within marriage; biblical eschatology refocused on homosexual license as the fulcrum around which civilization would crumble in the millennial holocaust. ${ }^{1: 4}$ Although religious traditionalists were alarmed early on, concerns with homosexuality did not gain traction as a social movement until gay people scored significant changes in the law. The

18:! See The Right to Be a Woman, in PHYLL.IS Schafly REP., Nov. 1973, at 6, discussed in MANSBRIDGE, supra note 13, at 110-12 (arguing that the ERA would, inter alia, abolish the husband's duty to support his wife).

${ }^{190}$ Opponents of both Roe and the ERA (whose open-textured language would have vested federal courts with considerable interpretive leeway) objected to unelected federal judges taking regulatory options away from state and local governments. MANSBRIDGE, supra note 13 , at 149.

${ }^{1: 11}$ See, e.g., Planned Parenthood v. Casey, 505 U.S. 833 (1992) (upholding state waiting period and parental-consent (for minors) requirements as acceptable burdens on women seeking abortions); Rostker v. Goldberg, 453 U.S. 57 (1981) (upholding exclusion of women from the draft requirement); Michael M. v. Super. Ct., 450 U.S. 464 (1981) (upholding statutory rape law applying only to males).

${ }^{192}$ William N. Eskridge, Jr., No Promo Homo: The Sedimentation of Antigay Discourse and the Channeling Effect of Judicial Review, 75 N.Y.U. L. REV. 1327, 1337 (2000).

${ }^{193}$ Leviticus 20:13 condemns "men lying with men" as "an abomination." Romans 1:26-27 condemns "unnatural" relations between women and between men.

${ }^{194}$ See Did Herman, The ANTIGaY Agenda: ORThodox Vision AND THE CHRISTIAN RIGHT 47-48, 61-63 (1997) (noting that Christianity Today was concerned with sexual promiscuity of all sorts before 1969 but focused on predatory homosexuality with increasing alarm after 1969). 
TFV movement had a test drive in the years 1975-1976, after California repealed its consensual sodomy law and a coalition of traditionalists tried (unsuccessfully) to place the repeal before the voters in a referendum. It had greater success after that. Anita Bryant's "Save the Children" campaign succeeded in overriding Dade County, Florida's ordinance protecting gay people against discrimination in 1977, and Jerry Falwell's Moral Majority won its first political battle in 1981, when it persuaded the U.S. House of Representatives to override the District of Columbia's repeal of its sodomy and adultery laws. ${ }^{195}$ As before, the countermovement was most successful when it was able to mobilize both extreme traditionalists, who maintained that the variation (homosexuality) and the associated conduct (sodomy) were malignant, and middle-of-the-roaders. The latter were persuaded by "no promo homo" arguments: giving homosexuals "special rights," these reforms would promote deviant conduct and undermine parental control over their children's sexuality and gender roles. ${ }^{196}$

Notwithstanding these successes, the TFV movement was not able to prevent most states from repealing their consensual sodomy laws or many cities and some states from adopting laws and executive orders barring sexual orientation discrimination by public or private institutions. As to lesbian and gay rights issues, the countermovement seemed to be waning-until the Hawaii Supreme Court ruled that the state's refusal to give same-sex couples the same marriage licenses accorded different-sex couples was impermissible sex discrimination under the state constitution. ${ }^{197}$ The TFV movement feasted on the possibility of Hawaii same-sex marriage like a lion on a gazelle. Overnight, the countermovement scored victories across the United States, as thirty-five states and the federal government adopted statutes refusing to recognize same-sex "marriages." In a final coup, TFV advocates persuaded the voters of Hawaii to amend the state constitution to override the judiciary's cautious move toward same-sex marriage. ${ }^{199}$

${ }^{195}$ Eskridge, supra note 192, at 1344, 1351-52.

${ }^{196}$ See id. at 1343-44 (outlining the structure of the no promo homo argument); id. at 1352-53 (arguing that the strategy underlying the TFV movement's successful 1992 campaign to amend Colorado's constitution was a no promo homo one).

${ }_{197}$ Baehr v. Lewin, 852 P.2d 44, 67 (Haw. 1993), affd sub nom. Baehr v. Miike, 910 P.2d 112 (Haw. 1996), enforced, No. 15689, 1996 WL 694235, at*22 (Haw. Cir. Ct. Dec. 3, 1996), affd, 950 P.2d 1234 (Haw. 1997) (mem.), rev'd, 994 P.2d 566 (Haw. 1999).

198 William N. Eskridge, JR., Equnlity Practice: Civil UNions aNd THE Future OF GAY RIGHTS 38 (2001) (listing nonrecognition laws adopted as of September 1, 2001).

${ }^{199}$ See Baehr v. Miike, 994 P.2d 566 (Haw. 1999) (table decision) (reversing trial 


\section{From a Politics of Recognition to Normal Politics}

What happens if the IBSM's politics of recognition is successful? Does the social movement end? At least three of the movements have enjoyed great formal success. The civil rights movement has eliminated almost all invidious race-based discriminations by the state and has obtained the enactment of laws barring private racial discrimination as well. The disability rights movement also has been relatively successful. Many fewer state and federal laws discriminate on their face against people with disabilities, and a range of statutes protect against private as well as public discrimination. ${ }^{200}$ The women's rights movement has also been highly successful in voiding de jure (but not always de facto) discriminations on the basis of sex. ${ }^{201}$ Success has changed all three social movements but has not come close to ending them. All three movements have engaged in concerted efforts to strengthen the enforcement of the anti-discrimination statutes enacted on their behalf, to influence agency and judicial interpretation of those laws, and to override unfavorable interpretations through legislation. $^{202}$ Significantly, these movements have also lobbied legislatures to distribute state benefits to people of color, people with disabilities, and sometimes women. In contrast, the pro-choice movement has been unable to prevent or overturn significant restrictions on abortion or to obtain state subsidies. ${ }^{203}$ Lesbian and gay groups have had the least amount of success in this regard, in part because their politics of recognition is so far from being fulfilled.

This last stage in an IBSM's life cycle is one in which the movement essentially becomes another group within the pluralist political system. I do not mean this in a pejorative sense, as in "special inter-

court injunction allowing same-sex marriage in light of state constitutional amendment adopted by referendum).

${ }^{200}$ See generally COLKER, supra note 51 (presenting a mini-history of disability rights reform and a collection of statutes and interpretations).

${ }^{201}$ Notwithstanding the defeat of the ERA, constitutional litigation under the Equal Protection Clause and legislative recodifications have erased most de jure sex discriminations.

${ }^{202}$ See, e.g., William N. Eskridge, Jr., Reneging on History? Playing the Court/Congress/President Civil Rights Game, 79 CAL. L. REV. 613 (1991) (surveying the history of congressional responses to Supreme Court decisions to show that civil rights, women's, and disability rights groups have been particularly successful in procuring legislative overrides of Supreme Court decisions).

${ }^{203}$ See Harris v. McRae, 448 U.S. 297, 326 (1980) (validating congressional Hyde Amendment which disallowed Medicaid coverage of abortion expenses); Maher v. Roe, 432 U.S. 464, 474 (1977) (upholding state refusal to fund abortions for poor women as part of Medicaid). 
est." A social movement that has succeeded in removing all or almost all formal legal discriminations against its members has "made it" in American politics, and there is no reason for it to disband. Indeed, the organizations that fueled the movement's politics of recognition can then serve as effective political arms of the group as a player in normal politics, and the utility of the preexisting organizations helps the group overcome collective action problems. To be sure, their opponents will claim that laws benefiting the minority are "special" rights, while the minority will justify the laws as "remedial." But these are nothing more than the claims of ordinary politics; the supporter of government price supports for milk presents them as remedying flaws in the market for agricultural goods, while the opponent charges that they are rent-seeking subsidies unrelated to the public welfare. Government set-asides based on race or sex, affirmative action programs by public employers and colleges, and hate crime laws are all rather typical products of the pluralist political system. What sets them apart is that they deploy classifications that remain charged criteria of normative decisions in our polity.

The success of an IBSM does not ensure the eradication of prejudice against or stereotypes about the minority group, but it does deepen the split between the two poles of the countermovement opposing it. True to their label, the pragmatists make peace with the new consensus but seek to preserve private space for traditionalists to self-segregate. They abandon their substantive stance altogether in favor of procedural space for tradition-based exclusions to be localized and privatized. In contrast, the true believers-the people for whom disdain for the formerly stigmatized trait is more deeply integral to their identities-are radicalized as they become a marginalized minority themselves. The Ku Klux Klan, the private militia movement, Operation Rescue, and all-male and all-white social clubs are examples of private guerilla groups resisting the anti-racism and anti-sexism norms that are now accepted in public culture. ${ }^{204}$

We are now in a position to sum up the dynamic politics of IBSMs. Table 1 describes the different kinds of politics entailed in trait-based discourse. The key variables are whether any part of society mobilizes in a way that focuses on the trait and how much variation in the trait society finds normatively tolerable or good. Along the lines of the first

${ }^{204}$ Good accounts of these groups are hard to find. For a fascinating study of a marginal traditionalist group, see Susan P. Koniak, When Law Risks Madness, 8 CARDozo STUD. L. \& LIT. 65 (1996), examining the Christian Common Law Movement in the nation's heartland. 
variable, politics moves from quadrant 1 to 3 if the stigmatized minority mobilizes to resist social and legal stigmatization, from 1 to 2 if a group invested in the status quo mobilizes out of fear of a powerless minority. In the former case, there is a politics of recognition; in the latter case, there is a politics of protection, where the minority seeks to protect itself against a fearful majority. If the minority and traditionalists both mobilize, there is a culture clash between politics of recognition and preservation. Along lines of the second variable, a movement from quadrants 1-2 to 3-4 usually reflects an emerging social consensus tolerating (but not embracing) variation of the trait within mainstream society. Movement from quadrants 3-4 to 5-6 reflects widespread public acceptance of the idea that the minority's variation is benign. Such a movement does not mean that people abandon their prejudices or stereotypes, only that public culture embraces the minority as a "good" and not just "tolerable" social group.

Table 1

Various Politics Arrayed Around a Stigmatized Minority

\begin{tabular}{|c|c|c|c|}
\hline & $\begin{array}{c}\text { Marginalized } \\
\text { Group That } \\
\text { Has Not } \\
\text { Mobilized }\end{array}$ & $\begin{array}{c}\text { Marginalized } \\
\text { Group Mobilizes }\end{array}$ & $\begin{array}{l}\text { Marginalized Group } \\
\text { Assimilated into } \\
\text { Pluralist System }\end{array}$ \\
\hline $\begin{array}{c}\text { Traditionalist } \\
\text { Citizens } \\
\text { Not Fearful }\end{array}$ & $\begin{array}{l}\text { [1] Status Quo } \\
\text { Politics. Sta- } \\
\text { ble status } \\
\text { quo, where } \\
\text { minority is } \\
\text { subordinate. }\end{array}$ & $\begin{array}{l}\text { [3] Politics of Rec- } \\
\text { ognition. The } \\
\text { minority group } \\
\text { asserts the benign } \\
\text { nature of the } \\
\text { stigmatized trait } \\
\text { and seeks repeal } \\
\text { of legal stigmas. }\end{array}$ & $\begin{array}{l}\text { [5] Normal Politics. The } \\
\text { minority group succeeds } \\
\text { in becoming part of the } \\
\text { pluralist political system. }\end{array}$ \\
\hline $\begin{array}{c}\text { Traditionalist } \\
\text { Citizens } \\
\text { Are Fearful }\end{array}$ & $\begin{array}{l}\text { [2] Politics of } \\
\text { Protection. } \\
\text { Status quo } \\
\text { groups } \\
\text { become } \\
\text { alarmed that } \\
\text { people with } \\
\text { stigmatized } \\
\text { trait are a } \\
\text { threat to the } \\
\text { status quo. }\end{array}$ & $\begin{array}{l}\text { [4] Culture Clash: } \\
\text { Politics of Recogni- } \\
\text { iion versus Politics } \\
\text { of Preservation. }\end{array}$ & $\begin{array}{l}\text { [6] Reverse Politics of Pro- } \\
\text { tection. Conflict contin- } \\
\text { ues, but traditionalists } \\
\text { are now marginalized } \\
\text { and seek protection } \\
\text { against public disap- } \\
\text { proval. }\end{array}$ \\
\hline
\end{tabular}


Quadrant 1 is the most potentially stable state of affairs: it is possible for the identity trait to remain a marker for status subordination, with the subordinated group unable to organize against their subordination and those invested in the status quo happy to leave well enough alone. There is no inevitability that a group in quadrant 1 will ever graduate to quadrants 3 or 4 . But if for any reason the minority group mobilizes as a social and then as a political movement, the politics of recognition (quadrant 3) will likely generate a responsive social movement seeking to preserve the status quo, such as the traditional family value movements responding to the gay liberation movement. This will push politics into that of culture clash (quadrant 4). If quadrant 1 is potentially stable, quadrant 4 is not, if history is any guide. Thus far, most minorities getting as far as a genuine culture clash have been able to move into the realm of quadrants $5-6 .^{205}$ This is a paradox of culture clashes: once the minority has mobilized enough to trigger a culture clash, it will probably be able to graduate into normal politics at some point; traditionalists' best hope for suppressing the minority is by keeping them pacified (quadrant 1) or terrorizing them (quadrant 2) before they get organized. Traditionalists have been able to nip potential social movements in the bud through massive Kulturkampfs against, for example, Mormon polygamists in the late nineteenth century and pedophiles in the late twentieth.

\section{Constitutionalization of Identity-Based Social Movement Politics and the Channeling Function of Law}

IBSMs are normative movements. The central prescription, the one from which others flow, is that a trait society has treated as a malign variation from the norm is, in fact, either a tolerable or a benign variation (or is no significant variation at all). A social group whose trait has traditionally been considered malign will take as its original stance (to the outside world at least) that its variation is tolerable: tacitly conceding the superiority of the majority's trait, the minority will initially just ask for tolerance. If that plea makes headway, the minority will probably seek full acceptance of its variation. So the natural

${ }^{205}$ The key variable is whether the trait or its associated conduct genuinely detracts from the needs of a good, well-functioning society. Homosexuality and most disabilities do not, and so I would expect those minorities to become part of the pluralist system. Traits associated with genuinely harmful conduct-pedophilia and drug addiction come to mind-have not yet yielded social movements that have emerged from quadrants 1 and 2, and it is unlikely that those stigmatized traits will become part of normal politics or even a serious politics of recognition. 
normative progression in a social movement is this:

malign variation $\Rightarrow$ tolerable variation $\Rightarrow$ benign variation

The countermovement will seek to halt or reverse the flow. Rhetorically, its members claim that the minority is challenging the norm itself, and other associated norms that are central to society's moral structure. Hence the traditionalists' talk of Armageddon: if the norm is sacrificed for "these people," a lot of norms will become fuzzy, and society will lose the ability to direct its members in productive directions.

Historically, this normative progression immediately became a progression of constitutional arguments. ${ }^{206}$ Although the terminology in this Article has shifted to and fro, the social movements I have been discussing are now called the civil rights movement, the women's rights movement, the abortion rights movement, the lesbian and gay rights movement, and the disability rights movement. Identity-based movements early on view themselves as asserting legal and constitutional rights as well as normative identities. Even within the majority's frame, whereby the minority trait is a malign variation, minority group members will maintain that they are entitled to all the protections of the rule of law, particularly procedural due process and freedom of speech protections. The majority will have to concede that point, but efforts will be made to limit expressive freedoms. Once the minority group starts emerging as a viable social movement, asserting that its trait is either a tolerable or a benign variation, its constitutional arguments will include equal protection as well as due process and freedom of speech claims. If the movement achieves success through the adoption of anti-discrimination laws (for the best example), the countermovement's politics of preservation will respond with its own constitutional arguments, in most cases rooted in freedom of speech and association.

Perhaps the biggest gap in sociological theories of social move-

${ }^{206}$ De Tocqueville's insight about the United States, that big public law issues all end up in court, is true for the state's stance toward IBSMs. Given the rightsprotecting tradition of the American judiciary, firmly established by 1945, and the specific text as well as traditions of the Equal Protection Clause and the First Amendment, minority groups poorly represented in the political process would naturally seek help from courts, which have their own interest in arbitrating political disputes through their super-political power of judicial review. Once the minority latches onto constitutional arguments, traditionalists will tend to respond with their own constitutional counterarguments. 
ments is their neglect of the role of constitutional law and discourse. Constitutional discourse is pervasive in all the kinds of politics involving IBSMs. This has the obvious effect of further empowering lawyers as the ideological leaders and strategists for the social movements, with the price being the ones I described earlier. A less obvious effect is that the public rhetoric of IBSMs in the United States has itself become constitutionalized. This is the grand channeling function of constitutional law for IBSMs: constitutional doctrine not only channels the energies of these social movements and countermovements, but also channels their rhetoric and perhaps even their ideologies in to the furrows plowed by judges and law professors.

Consider how the foregoing analysis operates at all levels of the politics of IBSMs.

\section{The Politics of Protection: (Procedural) Due Process and Freedom of Speech}

The minority groups' politics of protection (quadrant 2) was the first to be constitutionalized. Although private persons and firms can hassle and commit violence against the minority, middle-class Americans are nervous doing these things without the imprimatur of the state. In our constitutional tradition, anything the state does to an individual is limited by various procedural and substantive protections, most of which have been recognized under the Due Process Clause of the Fifth (federal government) and Fourteenth (state governments) Amendments to the Constitution. Thus, when African-American men were charged with rape or other serious crimes during apartheid, they had potential constitutional arguments against being railroaded into a conviction and a possible death penalty. Concededly, states routinely ignored or evaded those ostensible protections, but the Supreme Court sought to thwart this exercise of official power by prohibiting, under the Due Process Clause, railroaded state conviction and punishment of blacks because of prejudice, ${ }^{207}$ and by prohibiting, under the Equal Protection Clause, exclusion of blacks from juries. ${ }^{208}$ Later

207 See Moore v. Dempsey, 261 U.S. 86 (1923) (barring trial by mob); Powell v. Alabama, 287 U.S. 45 (1932) (requiring state-appointed counsel in capital cases); Brown v. Mississippi, 297 U.S. 278 (1936) (barring state torture to obtain convictions).

See Strauder v. West Virginia, 100 U.S. 303, 309-10 (1879) (invalidating a statute limiting juries to "white male persons"); Avery v. Georgia, 345 U.S. 559, 562-63 (1953) (ruling it unconstitutional to exclude blacks from jury venires by unannounced discriminatory practices); Batson v. Kentucky, 476 U.S. 79, 79 (1986) (ruling that discriminatory use of preemptory challenges is unconstitutional). 
precedents greatly expanded the due process protections for criminal defendants, which commentators believe to have been inspired by the Court's concern with state prosecution of racial minorities. ${ }^{20 ! 9}$ Once these expanded protections fell into place, they also provided some protections for gay men or female sex workers arrested for soliciting sex in public. These defendants had potential constitutional arguments to challenge their arrests, and other constitutional protections such as the right to counsel and trial by jury would, if invoked, raise the costs of prosecution. The homophile movement of the 1950s and early 1960s publicized these protections to their members and sought public support for toleration by trying to expose abusive police practices. $^{210}$

The politics of protection won many court victories under the Speech Clause as well as the Due Process Clause. The Warren Court read the Speech Clause of the First Amendment the way the ACLU had long urged: whatever society's view of a minority group or an oddball individual, the Speech Clause guaranteed them rights to speak and dissent, to associate for such purposes without state interference, to march and carry on, and otherwise to object to state and private treatment of them. ${ }^{21}$ While this jurisprudence was deployed to protect political dissidents and racial minorities in the most celebrated cases, it was also a shield for gay litigants who wanted the state to give them their own normative space. ${ }^{212}$

More important, the Speech Clause gave nascent IBSMs public space to organize their politics of recognition. The freedom of speech cases protected the birth control movement from the post office and other censors and thereby allowed the movement to get out its message to a larger receptive audience. ${ }^{213}$ In the wake of Brown and the various bus boycotts of the $1950 \mathrm{~s}$, southern jurisdictions outlawed

${ }^{209}$ See Louis Michael Seidman, Brown and Miranda, 80 CAL. L. REV. 673 (1992) (explaining the Warren Court's criminal due process activism as inspired by concern about discriminatory enforcement against African Americans).

${ }^{210}$ See, e.g., Your Rights in Case of Arrest, ONE, Jan. 1954, at 14 (providing fourteen recommendations on how to deal with the police in case of arrest); Editorial, Your Rights in Case of Arrest, ONE, Mar. 1961, at 4-5 (advising homosexuals on how "to guard against illegal search and seizure and illegal arrest").

${ }^{211}$ See supra text accompanying notes 128-33 (noting the Supreme Court decisions that created a constitutionally protected space for dissent and protest).

${ }^{212}$ See Eskridge, GaYlaw, supra note 14, at 111-25 (surveying First Amendment cases)

${ }^{219}$ See, e.g., United States v. One Package, 86 F.2d 737 (2d Cir. 1936) (interpreting the Comstock Act as not barring trade in diaphragms); United States v. Dennett, 39 F.2d 564 (2d Cir. 1930) (protecting sex education materials against censorship). 
and investigated the NAACP and constantly harassed Dr. King and other leaders of the SCLC. Their actions violated virtually every freedom guaranteed by the Bill of Rights. Although state judges cooperated in the violations, federal judges and executive department officials disrupted them episodically. And every time King went to jail on trumped-up charges, the civil rights movement gained nationwide publicity for its complaints against apartheid. Northerners and federal officials were forced to conclude that southern jurisdictions were operating outside the rule of law and that the Constitution as well as racial justice were on the line in the civil rights struggle.

The Speech Clause helped make Stonewall the galvanizing event that turned gay rights into a mass social movement. Under the Supreme Court's precedents, there was no doubt that lesbians and gay men could speak publicly about their sexual orientations, publish newsletters and magazines that could not be censored by the state (and under no circumstances be subjected to prior restraints), form clubs and organizations for associational and speech purposes, congregate pretty much as they wished, march and protest antigay actions, and so forth. These protections, which did not exist in the 1950 s, lowered the costs of coming out of the closet and forming group organizations. Once the Stonewall riots inflamed the consciousness of thousands of previously closeted gay men, lesbians, and bisexuals, more of them were willing to become involved in that social movement, engaging in expressive, often obnoxious, activities so clearly within the protection of the Speech Clause that seething police and censors did not even try to stop them.

The constitutional arguments associated with the politics of protection had a price tag for nascent IBSMs. To begin with, by making these arguments, minorities were subjecting themselves to state apparatuses and were conceding the authority of the state to govern their affairs. As Dr. King put it, "[o] ur conscience tells us that the [southern] law is wrong and we must resist, but we have a moral obligation to accept the penalty." ${ }^{214}$ Another cost rested upon the analytical structure of due process and freedom of speech arguments, which allowed minorities and judges to sidestep underlying moral and normative issues. Freedom of speech arguments rest on the supposition that everyone is entitled to express his views, no matter how wretched they are. ${ }^{215}$ Due process arguments rest upon the supposition that the state

\footnotetext{
${ }^{214}$ GarRow, BEARING THE CROSS, supra note 12, at 159 (quoting Dr. King).

${ }^{215}$ See, e.g., Texas v. Johnson, 491 U.S. 397, 421 (1989) (Kennedy, J., concurring)
} 
cannot discipline people except under the clearly articulated rules of law and according to traditional procedures, no matter how degraded those people might be. ${ }^{216}$ Thus, the state cannot censor speech because it is squalid, nor can the state deprive horrible people of their liberty without following traditional procedures and applying preexisting rules of law. While minorities could protect themselves by appeals to rights shared by the worst in society, such a stance suggested that people of color, the disabled, gays and lesbians, and women seeking abortions were the worst in society. So long as freedom of speech and procedural due process were the only arguments a minority group was making to protect its members, minorities might be understood to have "conceded" their inferiority. Finally, by making appeals to the most libertarian provisions of the Constitution, these minorities were not only foregoing appeal to the Equal Protection Clause, but were contributing to the anti-state tradition in American public law. Because the primary situs of oppression against most people of color, women, gay people, and the disabled were private actors, the minority's early embrace of a libertarian Constitution could, in the longer term, undermine the minority's ability to seek affirmative aid from the state.

2. The Politics of Recognition: (Substantive) Due Process and Equal Protection

As nascent IBSMs moved from the primarily defensive stance of protecting their members from state persecution to the more offensive one of repealing or nullifying state discriminations against their members, they moved from procedural to substantive due process lines of argument. Birth control advocates in the 1920s and 1930s invoked the rule of lenity, a procedural due process rule of statutory construction, to urge narrow construction of anti-contraception laws; ${ }^{217}$ pro-choice advocates did the same for anti-abortion laws in the 1960 s. $^{218}$ As these movements grew stronger, their advocates moved

(agreeing firmly that the Speech Clause protects a flagburning defendant, however "repellant" he and his conduct are to the Court).

${ }^{216}$ See, e.g., Papachristou v. City of Jacksonville, 405 U.S. 156 (1972) (overturning crime of being a "dissolute person" as too vague), followed in City of Chicago v. Morales, 527 U.S. 41 (1999) (invalidating a law aimed at controlling inner city gangs and hoodlums).

${ }^{217}$ See People v. Sanger, 118 N.E. 637 (N.Y. 1918) (narrowly construing New York's anti-contraception laws).

${ }^{218}$ See People v. Belous, 458 P.2d 194 (Cal. 1969) (narrowly construing California's abortion laws). 
toward substantive due process arguments in the 1940 s and 1970 s, respectively. Originally, advocates of these movements argued that the legislature had not clearly enough prohibited their activities; later, they maintained that the legislature could not regulate their activities. Griswold and Roe, of course, were the big victories for these movements. ${ }^{219}$ Women in the 1940s and 1950s and gay people in the 1960s and 1970s similarly relied on substantive due process and (for the latter) privacy arguments to challenge state discriminations against them. Such arguments succeeded in overturning the federal civil service exclusion of gay people, some consensual sodomy laws, most cross-dressing prohibitions, and many laws making sexual solicitation illegal. ${ }^{220}$ The NAACP's early challenges to segregation measures relied on substantive features of the Due Process Clause, and Bolling $v$. Sharpe ${ }^{221}$ (the companion case to Brown) relied on substantive due process to rule that the federal government's school segregation in the District of Columbia was unconstitutional.

The constitutional hallmark of an IBSM's shift to a politics of recognition, however, was a shift from due process aspirations to equal protection ones. ${ }^{222}$ The civil rights movement for African Americans epitomized this shift and inspired subsequent ones. Before World War II, the NAACP's court victories were often due process ones, but after the war its major victories were founded on equal protection claims. ${ }^{223}$ The basic stance was that any discrimination based upon a

219) Roe v. Wade, 410 U.S. 113 (1973) (invalidating criminal abortion statutes based on a substantive reading of the Due Process Clause); Griswold v. Connecticut, 381 U.S. 479 (1965) (invalidating the state's contraception law based on a constitutional right of privacy).

${ }^{224)}$ See ESKRIDGE, GAYLAW, supra note 14, at 104-11 (discussing the state cases dealing with the substantive right of privacy).

22134 U.S. 497 (1954).

${ }^{222}$ Note, however, that the initiation of a politics of recognition does not obviate the need for an ongoing politics of protection. Thus gay organizations have continued to challenge state laws and practices that gay people consider oppressive, while at the same time making broader equality arguments. Note, further, that equality types of arguments can and ought to be made under the Due Process Clause; so, for purposes of the argument in the text, it does not matter exactly what provision of the Constitution is invoked. William N. Eskridge, Jr., Destabilizing Due Process and Evolutive Equal Protection, 47 UCLA L. REV. 1183 (2000). Finally, do not forget that the IBSM's ultimate goal is social acceptance, not just legal equality.

${ }^{223}$ Compare Buchanan v. Warley, 245 U.S. 60, 82 (1917) (“[The] attempt to prevent the alienation of ... property ... to a person of color ... is in direct violation of the fundamental law enacted in the Fourteenth Amendment ... preventing state interference with property rights except by due process of law.") (emphasis added), with Brown v. Bd. of Educ., 347 U.S. 483, 495 (1954) ("[T] he plaintiffs and others similarly situated ... are, by reason of the segregation complained of, deprived of the equal protec- 
stigmatized trait was unconstitutional, at least for symbolic reasons. Although the civil rights movement sought economic advances as well, its core norm was dignitary: the state is not respecting black people unless it accords them all the same rights as white peopie.

Directly inspired by the civil rights movement, the first National Planning Conference of Homophile Organizations adopted this resolution in 1966: "Homosexual American citizens should have precise equality with all other citizens before the law and are entitled to social and economic equality of opportunity." ${ }^{224}$ This resolution marked a transition from the old homophile movement, whose core arguments rested upon the Due Process and Freedom of Speech Clauses, to the gay rights movement, which after Stonewall (in 1969) increasingly emphasized equal protection arguments. ${ }^{225}$ Likewise, the women's movement had long been ambivalent about claims of formal equality, but resolved those doubts, provisionally, at about the same time as gay rights advocates. NOW's purpose, also articulated in 1966, was "to bring women into full participation as the mainstream of American society NOW, assuming all the privileges and responsibilities thereof in truly equal partnership with men."226 This public aspiration of formal equality also expressed itself in the 1970 s with constitutional litigation pressed by the ACLU Women's Rights Project and the nearly successful ERA ratification effort. The birth control and pro-choice movements had originally founded their constitutional discourse on the right to privacy, but advocates subsequently augmented those arguments with equal protection ones. ${ }^{227}$ Indeed, in the $1980 \mathrm{~s}$ and 1990s, leading feminists argued that Roe $v$. Wade would have been better decided under the Equal Protection Clause than under the pri-

tion of the laws guaranteed by the Fourteenth Amendment.") (emphasis added).

${ }^{224}$ U.S. Homophile Movement Gains National Sirength, LADDER, Apr. 1966, at 4 (quoting the Conference's resolutions).

${ }_{225}$ See ESKRIDCE, GAYLAW, supra note 14, at 125-37 (surveying the government employment exclusion cases).

${ }^{226}$ Freeman, supra note 13 , at 798-99 (quoting NOW) (emphasis added). On the longstanding and continuing division between liberal and liberatory feminist thought, see RHODE, supra note 13, at 58-62; and Taylor, supra note 80.

${ }^{227}$ See Webster v. Reprod. Health Servs., 492 U.S. 490, 557 (1989) (Blackmun, J., dissenting) (suggesting a gender equality justification for preserving Roe, since the right to reproductive choice has become vital to the full participation of women in economic and political life); Eisenstadt v. Baird, 405 U.S. 438, 454-55 (1972) ("[B]y providing dissimilar treatment for married and unmarried persons who are similarly situated, [the] Massachusetts [contraception laws]... violate the Equal Protection Clause."). 
vacy-protecting Due Process Clause. ${ }^{228}$

Like the due process and speech cases, the equal protection cases were a tacit concession by potential rebels that they wanted to remain part of the pluralist constitutional polity.

In one sense, the later cases were an even more striking concession than the earlier ones. Unlike the due process and speech cases, the equal protection cases presented, rather than avoided, normative choices. By arguing that a classification (based on race, sex, sexual orientation, or disability, for instance) was arbitrary, plaintiffs were asking courts to make judgments that the minority's distinguishing trait was a tolerable variation from the norm, at least with regard to the regulatory matter in suit. ${ }^{229}$ Whereas the Speech Clause barred the state from censoring the sociopath's obnoxious expression, the Equal Protection Clause did not bar the state from refusing to employ the sociopath and from denying him other privileges. So long as the state had a sufficient policy basis for a regulatory discrimination, its rules would pass muster under the Equal Protection Clause. ${ }^{230}$

By the end of World War II, the Supreme Court was applying this standard through a rough sliding scale: suspicious classifications like race and ethnicity would be scrutinized more carefully to assure that the classification was strictly necessary to satisfy a more weighty public interest. $^{231}$ Although the Court in Brown did not emphasize the suspiciousness of the race-based classification, the Court applied the precedent to invalidate most state apartheid laws. After Loving $v$. Virginia, $^{2,32}$ it was apparent that race-based classifications triggered a wholly different level of judicial scrutiny than others did, and it became the constitutional goal of other groups to persuade the Court that the differentiating classification to which they were subject should

${ }^{228}$ Ruth Bader Ginsburg, Some Thoughts on Autonomy and Equality in Relation to Roe v. Wade, 63 N.C. L. REV. 375 (1985); Reva Siegel, Reasoning from the Body: A Historical Perspective on Abortion Regulation and Questions of Equal Protection, 44 STAN. L. REV. 261, 351 (1992).

${ }^{22 y)}$ See, e.g., Yick Wo v. Hopkins, 118 U.S. 356 (1886) (invalidating a commercial laundry ordinance because it was enforced on the basis of ethnicity rather than on the basis of its stated public safety rationale).

${ }^{2311}$ See Buck v. Bell, 274 U.S. 200 (1927) (holding that sterilization of statesupported inmates on the basis of feeblemindedness survived rational basis review and did not violate the Equal Protection Clause).

${ }^{231}$ Korematsu v. United States, 323 U.S. 214 (1944); Hirabayashi v. United States, 320 U.S. 81 (1943).

${ }^{292} 388$ U.S. 1 (1967) (holding that statutes that prevent marriages solely on the basis of race violate both the Equal Protection Clause and the Due Process Clause). 
be similarly treated. ${ }^{233}$ To garner that level of scrutiny, minority groups developed their own civil rights jurisprudence, which said, in effect: like people of color, our group is marked by an "immutable" trait which has served as the basis for discrimination; like race, our distinguishing trait "bears no relation to ability to perform or contribute to society." In this way, both judges and minorities were reading the Equal Protection Clause as a protection for groups that were marked and different, while at the same time being similar and integrable into society. Some scholars have read these cases as imposing assimilative strategies on minority groups. ${ }^{235}$ I do not go that far and would maintain only that these cases placed the burden on minority groups to show their "worth" to the nation's pluralist and market system, a burden minorities readily undertook. ${ }^{236}$

A deeper effect of IBSMs' reliance on equal protection and the other constitutional doctrines is that it empowered moderates within the social movements and disempowered radicals. These constitutional doctrines were tailor-made for minority leaders who favored integration of their group into mainstream institutions such as marriage, the workplace, and the armed forces. Win or lose, constitutional doctrines provided colorable challenges to exclusions from these institutions, and integrationists could hijack the social movement's agenda by pressing this kind of litigation, which not only attracted attention but whose minor successes provided the basis for quasi-permanent subcultural institutions. Radicals and separatists, in contrast, did not have this avenue for their claims that minorities

${ }^{233}$ See Craig v. Boren, 429 U.S. 190 (1976) (ruling that sex-based classifications shall be reviewed under an intermediate scrutiny standard); City of Cleburne v. Cleburne Living Ctr., 473 U.S. 432 (1985) (ruling that disability-based classifications need not be reviewed under a heightened scrutiny standard but under a "rational basis with bite" standard); Romer v. Evans, 517 U.S. 620 (1996) (ruling that sexual orientation-based classifications need to be reviewed under a "rational basis with bite" standard).

${ }^{294}$ Frontiero v. Richardson, 411 U.S. 677, 686 (1973) (Brennan, J., plurality opinion) (urging that sex discrimination be subjected to the same strict scrutiny as race discrimination, for reasons similar to those advanced in the ACLU brief for the petitioner).

${ }^{2355}$ See, e.g., Kenji Yoshino, Assimilationist Bias in Equal Protection: The Visibility Presumption and the Case of "Don't Ask, Don't Tell", 108 YALE L.J. 485 (1998) (critiquing the assimilationist bias in current equal protection doctrine).

${ }^{236}$ I do not think the structure of equal protection arguments press toward assimilation, or at least assimilation as understood by the melting pot. The structure of equal protection doctrine requires both that the minority be marked and that it be capable of contributing to society. That situation strikes me as leaving open many possibilities for diversity within our pluralist polity and our capitalist market. 
should develop their own new institutions to displace patriarchal marriage, capitalistic workplaces, and militaristic armies. ${ }^{237}$ Nor were radicals and separationists able to create sustained institutions to compete with those of the integrationists. Hence the assurance game feature needed for a social movement to take off for the long haul was much easier to achieve when the goals were integrationist.

\section{The Politics of Preservation: Federalism, Free Speech, and (Substantive) Due Process}

So long as traditionalists controlled the organs of state power to suppress minorities, the former had no positive constitutional politics. Theirs was a constitutionalism of denial: the minority group did not have the "rights" it claimed. But once minorities achieved some successes in the political or judicial arenas, traditionalists found their own affirmative constitutional voice. Between 1954 (when Brown was decided) and 1964 (when the Civil Rights Act was passed), southern segregationists developed a multifaceted constitutional jurisprudence. The federal government was violating states' rights by forcing national norms onto local political systems and was infringing on white people's rights of association by requiring their integration with people with whom they did not want to mix. ${ }^{238}$ Critics of Roe $v$. Wade adopted a similar combination of constitutional arguments. Their main argument has been that the Court's recognition of the rights of the

${ }^{237}$ Among the radical or separatist subgroups I have in mind are the black nationalists of the 1950s and 1960s, who were eclipsed by the NAACP and SCLC racial integrationists, see Gary Peller, Frontier of Legal Thought III: Race Consciousness, 1990 DUKE L.J. 758, 767-71 (discussing the shift toward integrationism in the 1960s and '70s); radical feminism, pro-sex feminism, and the lesbian nation of the 1970s, which were eclipsed by liberal and then cultural feminism, see ALICE ECHOLS, DARING TO BE BAD: RADICAL FEMINISM IN AMERICA 1967-1975, at 243 (1989) ("After 1975, a year of internecine conflicts between radical and cultural feminists, cultural feminism eclipsed radical feminism as the dominant tendency within the women's liberation movement, and, as a consequence, liberal feminism became the recognized voice of the women's movement."); sexual radicals and queer activists of the 1970s and 1980s, who have been eclipsed by the moderates of the same-sex marriage movement, see ESKRIDGE, EQUALITY PRACTICE, supra note 198, at chs. 1 \& 6 (providing an account of the samesex marriage movement and analyzing the three-pronged nature of the same-sex marriage debate); Nancy D. Polikoff, We Will Get What We Ask For: Why Legalizing Gay and Lesbian Marriage Will Not "Dismantle the Legal Structure of Gender in Every Marriage", 79 VA. L. REV. 1535, 1546 (1993) (opining that "an effort to legalize lesbian and gay marriage would make a public critique of the institution of marriage impossible").

${ }^{238}$ See EARL BLACK, SOUTHERN GOVERNORS AND CIVIL RIGHTS (1976) (surveying segregationist rhetoric in southern gubernatorial campaigns of the 1950s); SARRATT, supra note 185 (surveying segregationist reasoning). 
mother ignored the rights of the fetus, but pro-life advocates also maintained that the nationalization of the issue violated precepts of federalism. Opponents charged that the proposed ERA would federalize state law and would deprive women and children of protective legislation in the fields of employment and family law. ${ }^{239}$

Once the minority became a regular participant in normal politics and the state started imposing nondiscrimination obligations on traditionalists, traditionalists' arguments emphasized freedom of speech and association. Some of the precedents allowing minorities to associate with one another and speak publicly were invoked by traditionalists to protect their right to exclude minorities from their private clubs, associations, parades, and forums. ${ }^{240}$ And traditionalists insisted that their free speech rights protected them against government interference with racist or homophobic speech, or even maliciously racist conduct. $^{241}$ Embattled traditionalists have argued that the privacy cases also assure parents rights to control the information, images, and role models to which their children are exposed. ${ }^{242}$

Just as traditionalists deploy free speech and privacy arguments once a minority gains some degree of state protection, so too do they sometimes invoke equal protection arguments. Political claims that the state is giving a minority "special rights" sometimes translate into constitutional claims that statutes benefiting minorities constitute "reverse discrimination" in tension with the Equal Protection Clause. The Supreme Court in Adarand Constructors, Inc. v. Pena ${ }^{243}$ ruled that even remedial race-based classifications are subject to strict scrutiny.

By making, and often winning with, these constitutional argu-

230 See, e.g., MATHEWS \& DE HART, supra note 13, at 35-53 (reviewing the opposition posed by Senator Ervin, the leading Senate ERA critic).

${ }^{240}$ See, e.g., Boy Scouts of Am. v. Dale, 530 U.S. 640 (2000) (upholding traditionalists' rights of association by allowing their groups to exclude gay people); Roberts v. United States Jaycees, 468 U.S. 609 (1984) (rejecting traditionalists' assertion of associational rights as basis for their groups' exclusion of women).

${ }^{241}$ See, e.g., R.A.V. v. City of St. Paul, 505 U.S. 377, 380-81 (1992) (dismissing a charge of racist cross-burning in violation of a hate-crime ordinance because the ordinance impermissibly infringed upon free speech).

${ }^{242}$ See, e.g., StePhen Bransford, Gay Politics vs. Colorado and AMERICA: ThE INSIDE STORY OF AMENDMENT 2, at 70-80 (1994) (arguing that anti-discrimination laws invade the rights of straight families); ANITA BRYANT, THE ANITA BRYANT STORY: THE Survival. of OUR NATION's Families AND THE THREAT OF Militant HOMOSEXUALITY 114 (1977) (voicing concerns, as a mother, against "[k]nown homosexual schoolteachers and their possible role-model impact").

${ }^{243} 515$ U.S. 200 (1995) (overruling Metro Broadcasting, Inc. v. FCC, 497 U.S. 547 (1990) (applying intermediate scrutiny to minority preference programs of the Federal Communications Commission)). 
ments, traditionalists—no less than the minority-are paying homage to the legitimacy of the polity's regulatory authority. This may be a trivial feature so long as traditionalists are in the majority but looms much larger if the minority achieves overall public acceptance. If that happens, then traditionalists themselves will be the minority and will be subject to stringent and perhaps escalating state regulations. The embattled traditionalists may themselves become outlaws, but are less likely to do so if they trust the legal system to protect them against the most intrusive minority-rights regulations. At that point, their acquiescence in the legal system and its array of rights becomes quite important.

Whatever their ultimate direction, traditionalist rhetoric and thought, like that of the minority, are channeled by the law. Thus, traditionalists have found themselves making arguments that secularize their core religious or natural law vision, which risks losing their meaning in the translation and even altering their own selfunderstanding over time. ${ }^{244}$ For example, the devout fundamentalist who truly believes that same-sex marriage is contrary to the law of God now finds himself allied with the bigot who says "homosexuals are child molesters," with the lawyer who says "spouses have a right to defend their marriages against homosexual assault," and with the politician who says "normal people have a right not to associate with homosexuals and lesbians." Not only do the latter statements ignore the deep spiritual component of the devout's belief system, but in my opinion those secularized arguments actually change the belief system itself. My reading of the Gospels suggests that unfactual accusations about gay people and dependence on the state to bolster one's faith are inconsistent with Jesus' philosophy of love-and that the importation of these views into Christianity certainly changes and arguably corrupts that philosophy as articulated by Jesus.

Table 2 maps some of the ways that law, especially constitutional law, influences and even pervades discourse surrounding the emergence of IBSMs such as the gay rights movement.

${ }^{244}$ The worldview of most traditionalists draws heavily from premodern modes of thought, such as natural law and religion. Such thinking does not generate arguments that a federal court will recognize and so must be "translated" into the modern (rightsbased) mode of thought reflected in constitutional doctrine. Much is lost in the translation. 
Table 2

Constitutional Discourse and

the Politics of Identity-Based Social Movements

\begin{tabular}{|c|c|c|c|}
\hline & $\begin{array}{c}\text { Minority Group's } \\
\text { Politics of } \\
\text { Protection }\end{array}$ & $\begin{array}{c}\text { Minority Group's } \\
\text { Politics of } \\
\text { Recognition }\end{array}$ & $\begin{array}{c}\text { Traditionalist } \\
\text { Group's Politics of } \\
\text { Preservation }\end{array}$ \\
\hline $\begin{array}{l}\text { Normative } \\
\text { Aspiration }\end{array}$ & $\begin{array}{l}\text { Few aspirations. } \\
\text { Minority seeks to } \\
\text { reassign its trait } \\
\text { from malign toward } \\
\text { a tolerable variation. }\end{array}$ & $\begin{array}{l}\text { Ambitious. Minority } \\
\text { seeks to reassign its } \\
\text { trait from a malign } \\
\text { variation to tolerable } \\
\text { and then benign } \\
\text { variation. }\end{array}$ & $\begin{array}{l}\text { Reactive. Tradition- } \\
\text { alists seek to } \\
\text { reaffirm the minor- } \\
\text { ity's trait as a malign } \\
\text { variation or no } \\
\text { more than a tolerable } \\
\text { variation. }\end{array}$ \\
\hline $\begin{array}{c}\text { Constitutional } \\
\text { Bases } \\
\text { For Discourse }\end{array}$ & $\begin{array}{l}\text { Due Process } \\
\text { Freedom of Speech }\end{array}$ & $\begin{array}{l}\text { Equal Protection } \\
\text { (Substantive) Due } \\
\text { Process }\end{array}$ & $\begin{array}{l}\text { Freedom of Speech } \\
\text { Substantive Due } \\
\text { Process }\end{array}$ \\
\hline $\begin{array}{c}\text { Channeling Effect } \\
\text { of Law }\end{array}$ & $\begin{array}{l}\text { Acquiescence of } \\
\text { minority in state's } \\
\text { authority over its } \\
\text { members. Suppres- } \\
\text { sion of normative } \\
\text { discourse about the } \\
\text { minority's trait. }\end{array}$ & $\begin{array}{l}\text { Integration of the } \\
\text { minority into the } \\
\text { pluralist system. } \\
\text { Assimilation or } \\
\text { representation of } \\
\text { minority as similar } \\
\text { to mainstream. }\end{array}$ & $\begin{array}{l}\text { Modernization of } \\
\text { traditionalist dis- } \\
\text { course. Alienation } \\
\text { of traditionalists } \\
\text { from their root } \\
\text { beliefs. }\end{array}$ \\
\hline
\end{tabular}

\section{IDENTITY-BASED SOCIAL GROUPS, PUBLIC LAW, AND THEORIES OF JUDICIAL REVIEW}

The first two Parts of this Article have explored the important and multifaceted roles that law has played in the creation (Part I) and dynamics (Part II) of IBSMs. This Part reverses the inquiry: How have IBSMs affected the evolution of American public law, especially constitutional law? What role should constitutional courts play in the politics of identity-based social movements and countermovements?

The first inquiry is a descriptive one; the second is prescriptive. IBSMs have transformed American law by pressing for a broad range of anti-discrimination and group-remedial statutes, and by invigorating the enforcement of these new kinds of laws. Their most dramatic transformation has been in the arena of constitutional law. These mass movements have been both the occasion and the motivation for the Supreme Court to give hard bite to the Speech Clause's protection of expressive activities, to develop a broad constitutional right of privacy loosely moored to the Due Process Clause, and to create tiers of 
scrutiny under the Equal Protection Clause. At a more general level, IBSMs worked with judges to reconceptualize constitutional law as vigorously protecting minorities' efforts to bring their interests into the pluralist democratic process. As I shall argue in concluding this Part, this new constitutional role for judges can be criticized as both too timid and too activist, but on the whole it can be and has been deployed by cautious and thoughtful judges as a productive role for the judiciary to play in our republic.

\section{A. How IBSMs Have Changed Public (Statutory) Law}

The most obvious effect of IBSMs on American law is statutory. Legislatures have repealed almost all the race- and sex-based discriminations in American law, as well as many disability- and sexuality-based discriminations. States and municipalities prohibit a variety of discriminations by private as well as public employers and facilities. The federal government has adopted the Civil Rights Act of $1964,{ }^{245}$ the Voting Rights Act of 1965, ${ }^{24 i}$ the Rehabilitation Act of $1973,{ }^{247}$ the

${ }^{245}$ Pub. L. No. 88-352, 78 Stat. 241 (codified as amended in scattered sections of 42 U.S.C.)

42 U.S.C. $\$ \$ 1971,1973$ to $1973 \mathrm{bb}-4$ (1994).

${ }^{247} 29$ U.S.C. $\$ \$ 701-797 b$ (Supp. IV 1998).

${ }^{248} 42$ U.S.C. $\$ 2000 \mathrm{e}(\mathrm{k})(1994)$.

${ }^{249}$ Pub. L. No. 101-336, 104 Stat. 327 (codified as amended in scattered sections of 42 U.S.C. \& 43 U.S.C. (Supp. V 1999)).

${ }_{250}$ Pub. L. No. 102-166, 105 Stat. 1071 (codified in scattered sections of 42 U.S.C.).

251 See also the proposed Employment Nondiscrimination Act of 1996 (ENDA), reprinted in William N. ESKRIdGe, JR. \& NAN D. Hunter, SEXUAlity, Gender, AND THE LAW app. 4 at 1165-69 (1997). Although not contributing as deeply to American statutory law, countermovements have been able to enact important statutes of their own, most notably the first Hyde Amendment, Pub. L. No. 94-439 $\$ 209,90$ Stat. 1418, 1434 (1976), and the Defense of Marriage Act, 1 U.S.C. $\$ 7$ (Supp. II 1996).

${ }^{252}$ Equal Employment Opportunity Act of 1972, Pub. L. No. 92-261, 86 Stat. 111 (codified in scattered sections of 42 U.S.C. $\$ 2000 \mathrm{e}$ ) (amending the 1964 Act to extend job discrimination rules to state and federal employers). 
Pregnancy Discrimination Act of 1978 (PDA), ${ }^{248}$ the Americans with Disabilities Act of 1990 (ADA), ${ }^{249}$ the Civil Rights Act of $1991,{ }^{250}$ and other anti-discrimination laws. ${ }^{2.51}$ The impetus and sustaining push for all these statutes were IBSMs and their allies. These statutes have not only revised the rules of American law but have also created a new model of statutory law.

The new model has these features: pervasiveness, diversification, preference-transformation. Unlike most earlier American legislation, these new statutes were usually not limited to one industry or one kind of institution. Their prototype, the Civil Rights Act of 1964, as amended in 1972, ${ }^{252}$ imposed new rights and duties pervasively throughout our society and across different kinds of institutions. ${ }^{2.53}$ Unlike most prior laws, which were usually limited to particular institutions, the new anti-discrimination laws apply pervasively. They require employers, governments, landlords, and public accommodations to diversify, or at least to include or admit people who were previously excluded. Unlike most prior laws, which sought to solve social problems by increasing penalties for and therefore discouraging unproductive conduct, these new statutes seek to solve social problems by injunctive relief directly altering institutional decision making and indirectly seeking to change attitudes over time. The success of these statutes has depended on their ability to synthesize identity politics with the Weberian model of modern society, where advancement depends upon acts rather than status, impersonal merit instead of personal relationships. ${ }^{254}$ This represents a legal-normative revolution whose success is not assured, but which will continue to affect American law for the foreseeable future.

Indeed, the anti-discrimination laws pressed by IBSMs are emblematic of a relatively new form of law that John Ferejohn and I have dubbed super-statutes:

A super-statute is a law or series of laws that (1) seeks to establish a new normative or institutional framework for state policy and (2) over time does "stick" in the public culture such that (3) the super-statute and its institutional or normative principles have a broad effect on the

${ }^{253}$ The generalizations in the text apply also to comprehensive anti-discrimination statutes adopted by virtually all the states and to the ADA.

${ }^{254} 3 \mathrm{MAX}$ WEBER, ECONOMY AND SOCIETY: AN OUTLINE OF INTERPRETIVE SOCIOLOGY 998-1002 (Guenther Roth \& Claus Wittich eds., 1968); see ROSEMARY PRINGle, SECRETARIES TALK 84-103 (1988) (applying Weberian ideas to explain the ideology of modern anti-discrimination rules for workplaces). 
law-including an effect beyond the four corners of the statute. ${ }^{255}$

Such framework statutes, also characteristic of the nation's environmental laws, have a constitutive quality that gives them a quasiconstitutional flavor. The political energy flowing from IBSMs drives the implementation as well as enactment of these super-statutes. ${ }^{256}$ Courts and agencies will tend to apply these statutes liberally for three overlapping reasons: (1) the legislative mandate will be strongly remedial, and that will be reflected in the text and legislative history of the statute, and (2) the minority and its allies will lobby intensely for liberal constructions, which will be buttressed by (3) public opinion supporting remedial treatment. ${ }^{257}$ That tendency will be moderated to the extent a countermovement has been able to force compromises into the legislation or reveals its own political muscle after the law's enactment.

The evolution of Title VII, for example, has been driven more strongly by norms pressed by the civil rights and women's movements than by statutory text or legislative history. The statute on its face prohibits disparate treatment of an employee because of his race but, reflecting the political clout of employers in the original enactment

${ }^{2.55}$ William N. Eskridge, Jr. \& John Ferejohn, Super-Statutes, 50 DUKE L.J. 1215, 1216 (2001). Although there certainly were super-statutes before 1964, id. at 1223-25 (citing early institutional super-statutes creating the federal judiciary and the national bank); $i d$. at 1227 (detailing New Deal super-statutes); $i d$. at 1231-37 (discussing the Sherman Act and ensuing antitrust laws), the Civil Rights Act is not only an instant classic superstatute, but it has become an emblematic one in our polity. Anti-discrimination superstatutes have been deployed in pre-Charter Canada and the United Kingdom as substitutes for our Bill of Rights. Id. at 1265 .

${ }^{256}$ In two recent cases-the sex discrimination bar in Title VII and the disability rights provision in the Rehabilitation Act-the IBSM protected by the statute did not draft and was not primarily responsible for its enactment. See SCOTCH, supra note 15, at 45-59 (explaining the genesis and drafting of section 504 of the Rehabilitation Act); Charles Whalen \& Barbara Whalen, The Longest Debate: A Legislative HISTORY OF THE 1964 CIVIL RIGHTS ACT 115-18 (1985) (putting in context the opponents' supposed "killer amendment" adding "sex" to Title VII). In both instances, the beneficiary group mobilized around the new legal protection. See GRAHAM, supra note 145, at 221-32 (chronicling women's mobilization to force EEOC to enforce a sex discrimination provision); SCOTCH, supra note 15, at 60-120 (providing a detailed account on grassroots and lobbying pressure by the disability community to force HEW to issue strong section 504 regulations). The other statutes-the Civil Rights and Voting Rights Acts (racial minorities), Title IX and the PDA (women), the ADA (people with disabilities), and the proposed ENDA (gay people)-were pushed mainly by the IBSMs whose members stood to benefit from them, and they played a big role in the implementation of those statutes by the EEOC and HEW.

${ }^{257}$ Table 1 suggests that an IBSM's success in obtaining broad anti-discrimination legislation is evidence of an emerging consensus that variations in the identifying trait are at least tolerable and are moving toward benign. 
process, also permits employers to use job-related tests. ${ }^{258}$ Duke Power required certain grades of employees to have high school degrees or a certain score on a standardized test. Because the effect of this requirement was to prevent most black employees from moving up to better jobs, the NAACP challenged the practice. Relying on specific legislative history as well as the statutory text, the lower courts dismissed the complaint, but the Burger Court-normally attentive to legislative expectations and compromises-unanimously reversed in Griggs v. Duke Power Co. ${ }^{259}$ Chief Justice Burger's opinion relied on the integrative purpose of the statute to justify lawsuits challenging employment tests and other practices that had a disparate impact upon minorities but were without a legitimate job-based justification. Griggs is explicable neither as an exercise in legal analysis nor as an effort by the Justices to read their own values into the statute. ${ }^{260}$ Instead, it reflected an emerging political consensus in Washington, D.C., that Title VII would be a dead letter unless regulators and judges could examine employment practices that had discriminatory impacts. ${ }^{261}$

${ }^{258}$ Compare 42 U.S.C. $\$ 2000 \mathrm{e}-2$ (a) (1994) (prohibiting employment discrimination because of race), with $\$ 2000 \mathrm{e}-2(\mathrm{~h})$ (allowing employer use of job-related tests, unless applied with an intent to discriminate on the basis of race).

${ }^{259} 401$ U.S. 424 (1971), rev'g 420 F.2d 1225 (4th Cir. 1970).

260 See GRAHAM, supra note 145, at 386-90 (analyzing Griggs).

201 Following the EEOC's advice, the Nixon Administration joined the NAACP in asking the Court to review the lower courts' disposition. See id. at 385-86. Although the matter was more controversial in Congress, because a disparate impact rule exposed businesses to possibly significant litigation, both chambers rejected efforts to override Criggs. H.R. REP. NO. 92-238, at 21-22 (1971), reprinted in 1972 U.S.C.C.A.N. $2137,2156-57$; S. REP. NO. 92-415, at 14 (1971).

26: Accounts of the House floor amendment adding "sex" to Title VII can be found in WHALEN \& WHALEN, supra note 256, at 115-16; and Francis Vaas, Title VII: Legislative History, 7 B.C. INDUS. \& COM. L. REV. 431, 441-42 (1966).

${ }_{263}$ See 29 C.F.R. \$ 1604.10 (b) (1975); Gen. Elec. Co. v. Gilbert, 429 U.S. 125, 14042 (1976) (describing the EEOC's position as of 1966 and quoting the 1972 regulation). 
An even more dramatic example is the evolution of job discrimination law for women. Title VII's prohibition of employment discrimination because of sex was added through an opportunistic alliance between the feminist movement and the opponents of the civil rights bill. ${ }^{2+2}$ There was no strong congressional mandate for enforcing the provision, and the agency and courts did little with it for the first decade. Only after women became a politically potent social movement did enforcement change. For example, the EEOG initially opined that nothing in Title VII barred employers from discriminating on the basis of pregnancy, but, under pressure from feminist groups, reversed its position in 1972, the year Congress passed the proposed ERA by large margins. ${ }^{263}$ Although the Supreme Court invalidated the 1972 regulation, Congress swiftly overrode the Court by amending Title VII to include pregnancy as a form of sex discrimination. ${ }^{264}$ The Supreme Court was so chastened by the override that it has construed the PDA very broadly, and for the benefit of women, whose social movement had engineered the rebuke. ${ }^{26.5}$ Following the roadmap laid out by feminist scholars in the 1970s, the agency developed detailed guidelines regulating workplace harassment in 1980 . Still smarting from the PDA rebuke and alert to the new political equilibrium (as well as the voice of the nation's first female Supreme Court Justice), the Burger Court gave tentative approval to the guidelines in 1986 . $^{267}$ The Rehnquist Court-ordinarily more text-based in Gilbert).

${ }^{264}$ Pregnancy Discrimination Act of 1976, 42 U.S.C. $\$ 2000 \mathrm{e}(\mathrm{k})$ (1994) (overriding

${ }^{26.5}$ See, e.g., UAW v. Johnson Controls, Inc., 499 U.S. 187, 204-06 (1991) (construing the PDA to stop employers from barring pregnant women from working in hazardous parts of the workplace); Cal. Fed. Sav. \& Loan Ass'n v. Guerra, 479 U.S. 272, 292 (1987) (refusing to construe the PDA to preempt a state law giving unique advantages to pregnant workers). (1998).

${ }^{2(i, i}$ Vicki Schultz, Reconceptualizing Sexual Harassment, 107 YALE L.J. 1683, 1704

${ }^{267}$ Meritor Sav. Bank v. Vinson, 477 U.S. 57, 72 (1986) (ruling that some forms of workplace sexual harassment are actionable under Title VII).

${ }_{2 n 8}$ See Faragher v. City of Boca Raton, 524 U.S. 775, 804 n.4 (1998) (finding that Congress had ratified the earlier EEOC regulations); Burlington Indus., Inc. v. Ellerth, 524 U.S. 742, 765 (1998) (creating detailed judge-made rules for an employer's liability for actions of harassing employees).

${ }_{269}$ See, e.g., UAW v. Johnson Controls, Inc., 499 U.S. 187 (1991) (Blackmun, J.) (adopting a liberal construction of the PDA); see also id. at 223 (Scalia, J., concurring) (adopting Judge Easterbrook's construction in the lower court); School Bd. v. Arline, 480 U.S. 273, 284-86 (1987) (Brennan, J.) (adopting a liberal construction of the Rehabilitation Act as it applies to persons having contagious diseases). 
its constructions of statutes and no friend to progressive causes-not only reaffirmed the guidelines in 1998 but created a detailed set of rules for employer accountability, notwithstanding the lack of statutory support or delegation. ${ }^{268}$ The Court's relatively liberal approach to sexual harassment owes much to the normative consensus that the women's movement has brought to the issue: businesses join feminists and Republicans join Democrats in agreeing that sexual harassment does not belong in the workplace.

Thus, when an IBSM has been successful in bringing normative consensus to an issue of public law, that consensus has affected the evolution of statutes adopted at the behest of the IBSM. It is for this reason that conservative as well as progressive judges have construed the Voting Rights Act, the PDA, and the Rehabilitation Act dynamically and liberally to carry out anti-discrimination purposes that were once controversial but that have now saturated American public culture. ${ }^{269}$ There has been a political equilibrium as to such issues: even if a court were to trim back important voting protections, the political system would amend the statute to reinstate the settled meaning. Conversely, issues such as race- or sex-based affirmative action or discrimination against people with eyeglasses are not ones where we have a public consensus. ${ }^{270}$ Where there is no such consensus, regulators and judges have substantial discretion to treat these issues as they think best. Accordingly, at some point, the agency and courts will set new limits to the obligations imposed by the statute.

Like other statutes, an anti-discrimination super-statute has an expected life cycle-from a burst of political energy at birth and in its youth, through a mature adulthood, culminating in a wasting away during senescence. ${ }^{271}$ Anti-discrimination laws have been distinguished by the intensity of their remedial purpose, which agencies and courts usually carry out for a relatively long period of time, and by the predictable movement from combating de jure forms of discrimi-

${ }^{270}$ Cf. Sutton v. United Air Lines, Inc., 527 U.S. 471 (1999) (settling an intense debate over whether the ADA covers people with correctable vision by holding that it does not); Johnson v. Trans. Agency, 480 U.S. 616, 640-42 (1987) (reaffirming, over a heated dissent, Title VII's allowance of voluntary affirmative action under certain circumstances).

${ }^{271}$ The idea of a statute's life cycle is adapted from MARVER H. BERNSTEIN, REGULATING BUSINESS BY INDEPENDENT COMMISSION 74-91 (1955).

${ }^{272}$ GORDON S. WOOD, THE RADICALISM OF THE AMERICAN REVOLUTION 5 (1991). 
nation ("No women need apply") toward de facto ones (women are hired but are harassed on the job or are not promoted if they have children). At some point, courts will halt the IBSM-inspired agency's expansion of the statute, and the legislature will debate whether to accept the court's limits. Generally, legislatures will support substantial effort to eliminate many of the de facto forms of discrimination-until political support for the statute wanes. At that point, ordinary politics is the order of the day, and enforcement of the statute will shift from being considered a moral crusade toward being a strategic game. If the public comes to see the statute that way, I hypothesize that its political support will sink and it will be vulnerable to diminishing relevance or even repeal. Diagram 3 illustrates the life cycle I have described.

\section{Diagram 3 \\ The Life Cycle of an Anti-Discrimination Super-Statute}

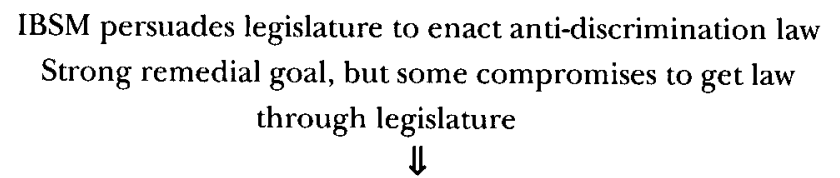

IBSM allies staffing agency press for liberal construction of statute; courts go along

Legislature debates exemptions and expansions, with IBSM usually prevailing $\downarrow$

De jure discriminatory practices change

Agency tackles de facto discrimination, sometimes limited by courts

Legislature tends to override courts in favor of attacking de facto discrimination

$\Downarrow$

Political support for further expansion of statute weakens Agencies and courts reluctant to expand statute further $\Downarrow$

[Statute perceived to have higher social costs, leading to cutbacks]

B. How IBSMs Have Changed Constitutional Law

Social movements can influence constitutional law in no fewer than three ways. IBSMs have not only affected constitutional law in 
each of these ways but have profoundly affected how each modality of constitutional change operates.

\section{Constitutional Amendments-and Super-Statutes} as a Substitute for Them

One way social movements can change the Constitution is by sponsoring amendments to it. The American Revolution and the adoption of the Constitution were, in a genuine sense, the consequence of social movements. ${ }^{272}$ Several important substantive amendments to the Constitution have been a direct reflection of important social movements in American history. ${ }^{273}$ Since the advent of IBSMs as important political phenomena, however, this has not been an important mechanism for constitutional change. After 1933, there have been no major substantive amendments; the closest to adoption was the failed ERA. The coincidence of the rise of IBSMs and the decline of formal amendments to the Constitution is no accident. Identity politics, as explicated in this Article, raises deep issues regarding public norms and relative social status that are deeply divisive. They are too conflictual to be resolved by the lengthy super-majoritarian processes Article V lays out for changing the Constitution.

Now that formal constitutional amendment has become impractical, constitutional change has come in other ways. One way is through super-statutes. The civil rights and women's movements have effected profound quasi-constitutional changes in part through the enactment and vigorous enforcement of statutes like Title VII, Title IX, and the Voting Rights Act. As noted above, these statutes have reached beyond the command-and-control model of lawmaking and have deeply affected public norms and, to some extent, private attitudes. A second way that constitutional change now occurs is through dynamic interpretations of the Constitution by the Supreme Courtan arena where IBSMs have had an even greater influence.

\section{Dynamic Constitutional Interpretation}

Social movements can affect constitutional law by generating new kinds of cases and challenging judges to apply or expand existing constitutional rules and precedents to grant relief in those cases. The

${ }^{273}$ See, e.g., U.S. CONST. amends. XII-XV (responding to the abolitionist movement), XVIII, repealed by U.S. CONST. amend. XXI (responding to the temperance movement), and XIX (responding to the women's movement). 
post-Reconstruction Constitution is filled with grand phrases-equal protection, due process, freedom of speech - that can be applied in a variety of ways, depending on the case's context, the legal precedents, and the sympathies of the judge. One goal of a social movement is to show how its grievances fit within the purpose of a provision of the Constitution. Many abolitionists, for example, argued that slavery was contrary to the Constitution and urged narrow readings of the fugitive slave provision in Article IV. These arguments were generally unsuccessful in court, because cautious judges either disagreed with them as a matter of law or morality or felt they had insufficient political cover for accepting them. ${ }^{274}$ IBSMs in the twentieth century were much more successful in using their cases as vehicles for effecting constitutional change. The classic example is the NAACP's Inc. Fund, which won Brown $v$. Board of Education, ${ }^{275}$ the greatest constitutional decision of the past century. Feminist and disability groups have also enjoyed successes. All of these groups have persuaded the Supreme Court to overrule precedents and read the Equal Protection Clause very dynamically. ${ }^{276}$ Such constitutional dynamism does not operate haphazardly, however.

Under the premises of political pluralism, constitutional law can change if a longstanding political equilibrium is destabilized, and it must change if the public culture settles into a new political equilibrium. If public culture is committed to a regime whereby the minority's trait is generally considered malign and the proper basis for exclusions, the Supreme Court will be very reluctant to strike down any significant state discrimination in the short term, because the Court would fear that such an order would not be enforceable ${ }^{277}$ and would

${ }^{274}$ See Ableman v. Booth, 62 U.S. (21 How.) 506, 509, 526 (1859) (Taney, C.J.) (holding the fugitive slave law constitutional and confirming that the federal district courts have jurisdictional authority to hear cases arising under it), rev'g In re Booth, 3 Wis. 1 (1854); ROBERT M. COVER, JUSTICE ACCUSED: ANTISLAVERY AND THE JUDICIAL PROCESS 202 (1975) (explaining moral and political dilemmas faced by anti-slavery judges in fugitive slave cases).

275 U.S. 483 (1954).

${ }^{276}$ See Ginsburg, supra note 2, at 161 (conceding that the Court's sex discrimination jurisprudence required a "boldly dynamic interpretation" of the Equal Protection Clause); Earl M. Maltz, Brown v. Board of Education, in ConstituTIONAL STUPIDITIES, Constitutional Tragedies 207 (William N. Eskridge, Jr. \& Sanford Levinson eds., 1998) (arguing that Brown and other race decisions are deeply inconsistent with the expectations of the Fourteenth Amendment's ratifiers).

${ }^{277}$ See Dan M. Kahan, Gentle Nudges v. Hard Shoves: Solving the Sticky Norms Problem, 67 U. CHI. L. REV. 607 (2000) (arguing that courts will pull back from announcing rulings they do not think they can enforce). 
fear political retaliation from Congress. ${ }^{278}$ In the medium term, a Court issuing such an order would be susceptible to packing-and sooner or later the offending doctrine would be overturned or narrowed by Justices more in tune with the political equilibrium. ${ }^{279}$ This institutional dynamic loses most of its coercive force once the consensus is shattered by an IBSM. At that point, the Court has a great deal of slack: it can either leave the old rules in place or overturn some of them without much risk of political retaliation. By overturning segregationist rules, the Court places the old regime on the political agenda and might hasten its demise. If a national consensus develops in favor of tolerable or even benign variation in the formerly stigmatized trait, the Court will become part of the clean-up process. In this event, if the Court were to uphold category discriminations the country was ashamed of, the Court would face strong criticism and short- or medium-term political pressure to conform.

To illustrate, it was probably not possible for the Supreme Court to overturn apartheid in the $1890 \mathrm{~s}$, when Plessy was decided. But once the civil rights movement undermined the political consensus in favor of racial segregation, the door was open for challenge, and the Court overturned particular exercises in the 1940s and then essentially invalidated the entire system of laws in Brown and its progeny. Changed attitudes also gave President Truman slack to desegregate the armed forces. Both the President and the Court could have ducked the issue and done nothing in the 1940s, but the normative uneasiness about apartheid made it possible for them to act without devastating consequences. (Some in both branches already thought the matter no longer amenable to any action but desegregation.) By the 1960s, when the Court faced its toughest cases, the constitutionality of bars to different-race cohabitation and marriage, it may have had little choice but to invalidate the bars-even though the Court had to overrule binding precedent and to ignore the likely intent of the framers of the

${ }^{278}$ See John Ferejohn, Independent Judges, Dependent Judiciary: Explaining Judicial Independence, 72 S. CAL. L. REV. 353, 382 (1999) (arguing that when the judiciary goes against a national consensus, it risks being stripped of its jurisdiction or having its orders overturned by the legislature).

${ }^{279}$ Although Congress has never removed a sitting Justice and increasing the size of the Court backfired against FDR in 1938 and 1939, neither is an idle threat against a Court defying a political consensus about which people have strong feelings. In any event, unpopular Courts have been readily enough tamed by the election of Presidents intent on replacing retiring Justices with more sympathetic ones. This happened during the Jackson, Lincoln, Roosevelt, Nixon, and Reagan administrations. 
Equal Protection Clause to do so. ${ }^{280}$

Similarly, the birth control movement not only made it possible for the Court to decide Griswold the way it did, but made it likely. (Indeed, the main surprise is that it took the Court so long to adjudicate the Connecticut contraception law on its merits; by 1965, only two states had such laws, and they were erratically enforced.) The normative progress made by the pro-choice movement gave the Supreme Court a lot of discretion in deciding Roe $v$. Wade, which the Court chose to exercise by invalidating all the existing abortion-regulatory laws. The power of the women's movement was such that the Court felt impelled in the 1970 s to rule unconstitutional most invidious sex discriminations. Because the women's movement did shift public norms to a relatively anti-discrimination baseline, it was able to do through the Equal Protection Clause virtually everything the ERA would have accomplished had it been ratified and added to the Constitution. ${ }^{281}$

The foregoing logic explains why the Supreme Court has borne so much heat for the majority opinion in Bowers $v$. Hardwick. ${ }^{282}$ The Court treated the case as one where the old political equilibrium (homosexuals should be in jail) may have been destabilized but where there was no new equilibrium. ${ }^{283}$ The Court may have been right about that in 1986, but just barely so, as the country was in the process of settling on a public consensus that gay and lesbians should be tolerated but not encouraged. The Court's subsequent decision in Ev-

280 See Loving v. Virginia, 388 U.S. 1 (1967) (holding that Virginia's statutory ban of interracial marriages violated the Fourteenth Amendment); McLaughlin v. Florida, 379 U.S. 184, 188 (1964) (holding a Florida statute prohibiting cohabitation of unmarried couples of different races unconstitutional and overruling Pace $v$. Alabama, 106 U.S. 523 (1883)). Even Professor Michael McConnell, who believes Brown was rightly decided under originalist premises, Michael W. McConnell, Originalism and the Desegregation Decisions, 81 VA. L. REV. 947 (1995), concedes that Loving was inconsistent with the original intent of the ratifiers of the Fourteenth Amendment.

${ }^{281}$ See MANSBRIDGE, supra note 13 , at 45-59 (supporting the proposition in text by a detailed survey of the cases).

${ }^{282} 478$ U.S. 186 (1986). Poor Justice White wrote an opinion for the Court that is no meaner or more poorly reasoned than any number of other opinions the Court (or Justice White) handed down in the last generation. For a much harsher and even less sophisticated opinion, see Boutilier v. INS, 387 U.S. 118 (1967), which held that all "homosexuals" and even "bisexuals" fell under an immigration exclusion for people "afflicted with psychopathic personality."

"283 Hardwick, 478 U.S. at 193-94 (emphasizing that half the states still made consensual "homosexual sodomy" a crime, which suggests that there was not the public consensus the Court had found in Loving, for example). 
$a^{284}$ was, as the dissenters charged, functionally inconsistent with Hardwick and unsupported by traditional sources of law, ${ }^{285}$ but the Court suffered little-and, in my view, not a whit-from the decision because it perfectly reflected the new consensus. Any fear that the Court would move too fast in protecting gay people was disabused by Boy Scouts of America $v$. Dale, ${ }^{286}$ where the Court vigorously protected the rights of TFV associations to protect themselves against even the perception that they "promoted" or "encouraged" homosexuality.

Political equilibrium theory suggests the following dynamics of constitutional evolution. So long as the minority is highly unpopular, judges will do little for that minority beyond ensuring that minimal rule of law guarantees are applied to its members. Once the minority organizes, however, judges realizing that the political situation is suddenly more fluid will be more careful and usually more protective in dealing with its members. But the judiciary will not stick out its collective neck unless the minority persuades the polity that its variation is at least tolerable. In that event, judges will tend to be more aggressive against laws penalizing the minority. (Their aggressiveness will be tempered if a countermovement calls the IBSM's progress into question.)

\section{Altering the Structure of Constitutional Doctrine}

There is a third way social movements can change constitutional law. In the process of challenging segregation-preserving precedents and seeking minority-protective ones, social movements can contribute to changes in the doctrinal structure of constitutional inquiry. Akhil Amar has shown how the Reconstruction Amendments changed the Constitution in this way, not only creating new equality and voting guarantees, but also ensuring that both new and old kinds of individual rights would be directly enforceable against the states. ${ }^{288}$

284517 U.S. 620 (1996).

${ }^{285}$ See Romer, 517 U.S. at 640-41 (Scalia, J., dissenting) (citing Hardwick and asserting that " $[\mathrm{i}] \mathrm{f}$ it is constitutionally permissible for a State to make homosexual conduct criminal, surely it is constitutionally permissible for a State to enact other laws merely disfavoring homosexual conduct"); (f. Louis Michael Seidman, Romer's Radicalism: The Unexpected Revival of Warren Court Activism, 1996 SUP. CT. REV. 67, 104 (criticizing Justice Scalia's dissenting opinion in Romer).

${ }^{286} 530$ U.S. $640(2000)$.

${ }^{287}$ See id. at 644 (striking down a state anti-discrimination law requiring that the Boy Scouts allow the gay plaintiff to continue as a scoutmaster, on the grounds that such requirement violated the Boy Scouts' right of expressive association).

${ }^{283}$ AKHIL REED AMAR, THE BILl OF RIGHTS: CREATION AND RECONSTRUCTION 
At the most general level, IBSMs had a similarly dramatic impact in the twentieth century. Their politics contributed to a shift in constitutional focus from the structural Constitution of the founding era and the freedom-of-contract Constitution of the Lochner era to the Carolene Constitution of the mid- and late-twentieth century. The original Constitution sought to protect liberty by making it hard for the national government to act and by reserving most matters for state and local regulation. The Civil War Amendments created a new focus on direct enforcement of individual rights against state and local governments; the Supreme Court's interpretation of the Fourteenth Amendment protected economic liberties much more strongly than other potential rights, such as speech and equality ones. The Carolene Constitution reflected a move away from protecting economic liberties per se, and toward protecting against state and local efforts to lock in the power of ruling classes ${ }^{289}$ and to seek rents from (and thereby undermine) interstate markets. ${ }^{2: 0}$ The asserted goal of the Supreme Court in this Carolene phase of its history has not been to impose its understanding of substantive justice onto governance, but has instead been to referee the functioning of the political process. ${ }^{291}$ Thus the

(1998).

${ }^{289}$ See United States v. Carolene Prods. Co., 304 U.S. 144, $152-53$ n.4 (1938) (Stone, J.) (stating that presumption of constitutionality does not apply when a law seeks to entrench controlling class or places unfair burdens on "discrete and insular" minorities).

${ }^{290}$ See S.C. State Highway Dep't v. Barnwell Bros., 303 U.S. 177, 190 (1938) (finding that a state may impose safety measures but cannot export costs to other states, in an opinion written by Justice Stone, who also authored Carolene Products); Mark Tushnet, Rethinking the Dormant Commerce Clause, 1979 WIS. L. REv. 125 (elaborating on the Barmwell Brothers idea).

${ }^{291}$ See JOHN HART Ely, DEMOCRACY AND DisTRUST: A THEORY OF JUDICIAL REVIEW (1980) (explicating a "representation-reinforcing" theory of judicial review that is consistent with underlying democratic assumptions of our judicial system, and is constructed to enlist the courts in helping to make these assumptions a reality); Bruce A. Ackerman, Beyond Carolene Products, 98 HARv. L. REV. 713, 715 (1985) (“[T] he Carolene solution is to seize the high ground of democratic theory and establish that the challenged legislation was produced by a profoundly defective process."). The Carolene philosophy of judicial review is part of a larger reconceptualization of the role of judges that took shape in the 1930 s, a remarkable period that saw the New Deal take shape, the Roosevelt Court announce the outlines of the new philosophy in Carolene and Barnwell Brothers, and legal academics move toward the refinement of a "legal process" school of jurisprudence and law teaching. See EDWARD A. Purcel.l, JR., ThE Crisis of Democratic Theory: Scientific Naturalism \& THE Problem of Value (1973) (discussing approaches to understanding and teaching the process of jurisprudence of the early twentieth century); Neil Duxbury, Faith in Reason: The Process Tradition in American Jurisprudence, 15 CARDOZO L. REV. 601 (1993) (exploring the history and evolution of process jurisprudence, which is premised on a faith in reason); Wil- 
Court ensures that local elites do not suppress criticism and opposition to their policies and public norms (freedom of speech), do not deny fundamental rights to marginalized people (substantive due process), and do not create a permanent caste of citizens whose supposed inferiority is a basis for state discrimination against them (equal protection).

The Carolene philosophy was in large part a response to the civil rights movement. Indeed, it seems tailor-made to address the concerns of IBSMs. The civil rights movement represented the interests of the classic "discrete and insular minority," and all subsequent IBSMs claim to be under-represented in the political process because of "prejudice" (the term in Carolene) against them. The Carolene concern about political insiders suppressing the ability of outsiders to express themselves and organize politically was most dramatically illustrated by the operation of apartheid on people of color. And we know from archival sources and first-person accounts that Justice Stone (the author of Carolene) and some of his colleagues were specifically inspired by the dissonance between America's image of freedom and democracy (contrasted with the totalitarian Nazis and, later, Communists) and the experience of blacks and other trait-based minorities in this country. ${ }^{292}$ Not unimportantly, the Carolene philosophy culminated in a series of civil rights precedents that over time have brought the U.S. Supreme Court worldwide acclaim and admiration, enhanced its legitimacy, and increased its power in our polity. By presenting itself as a neutral arbiter of the political process, the Court has involved itself in most of the interesting issues of the day, enabled its preferences to affect public discourse-and enhanced its legitimacy even amid the occasional blunder. This has created a mutual dependence: new IBSMs have been inspired by what the Court did to empower the civil rights movement and therefore brought their petitions to the Court, which has had the luxury of picking and choosing which claims it wants to advance and which to suppress (for the time being). To the extent the Carolene philosophy has been a public relations success for the Court, the Justices owe some debt to IBSMs and their publi-

liam N. Eskridge, Jr. \& Philip P. Frickey, Introduction to Henry M. HAR'T, JR. \& AlberT M. SACks, The LeGal. Process: Basic Problems in the Making and APPlication of LAW, at li, liv-lxxxv, xci-xcvi (1994) (discussing the background and birth of the legal process school of thought).

${ }^{292}$ See Bixby, supra note 97, at 764-67 (discussing the Court's tilt in favor of minority protection signaled by footnote 4 of Carolene); Louis Lusky, Minority Rights and the Public Interest, 52 YAlE L.J. 1 (1942) (presenting an explanation by the law clerk who drafted Carolene footnote 4 and detailing why it is important to protect minorities). 
cists.

By presenting interesting new cases in the context of the overall Carolene philosophy, IBSMs have also figured in the major doctrinal developments for the Court's freedom of speech, due process, and equal protection jurisprudence. The Supreme Court applied the Speech Clause with little bite to early radicals and syndicalists (1910s1930s), generally allowing the state to suppress illiberal groups allegedly threatening violent disruption or even overthrow of our form of government. $^{293}$ The next big wave of cases (1950s-1960s) were brought by publishers of sexual materials, the NAACP and other civil rights associations, and peaceful protest marchers. ${ }^{294}$ These cases were much more congenial to the flourishing of a strong First Amendment, because the people being censored and suppressed were relatively peaceful, liberal, and pluralist. The civil rights cases in particular cried out for strong protection, because southern sheriffs, mayors, and even judges were seen as acting outside the rule of law, and, indeed, as acting little differently than the Nazis. From these cases emerged a Speech Clause that protected not only "speech," but also association and expressive conduct (such as marching). The cases also strengthened the notion that freedom of speech must be guaranteed any person or group, however reprehensible their philosophy, so long as they are willing to abide by the rules of the game. ${ }^{295}$ The Speech Clause's

${ }^{299}$ See, e.g., Abrams v. United States, 250 U.S. 616 (1919) (upholding conviction of war protesters under the Espionage Act of 1917); Gitlow v. New York, 268 U.S. 652 (1925) (upholding conviction of an anarchist for arson); Whitney v. California, 274 U.S. 357 (1927) (upholding conviction of a Communist under the state's Criminal Syndicalism Act). On the early cases, see David M. Rabban, The Emergence of Moderm First Amendment Doctrine, 50 U. CHI. L. REv. 1205 (1983).

294 See, e.g., NAACP v. Alabama ex rel. Patterson, 357 U.S. 449 (1958) (overturning court order requiring NAACP to turn over its membership lists); A Book Named "John Cleland's Memoirs of a Woman of Pleasure” v. Attorney Gen., 383 U.S. 413 (1966) (overturning designation of a bawdy novel as obscene); Shuttlesworth v. City of Birmingham, 394 U.S. 147 (1969) (overturning conviction of civil rights protest leader). On the changes in First Amendment doctrine occasioned by the new identity politics cases, see Nan D. Hunter, Expressive Identity: Recuperating Dissent for Equality, 35 HARV. C.R.-C.L. L. REV. 1 (2000).

${ }^{295}$ Namely, no violence and adherence to reasonable time, place, and manner restrictions by the state.

${ }^{206}$ See Brandenburg v. Ohio, 395 U.S. 444 (1969) (per curiam) (invalidating a criminal syndicalism statute under which a Klan leader was convicted on grounds that it violated the First and Fourteenth Amendments); Boy Scouts of Am. v. Dale, 530 U.S. 640,648 (2000) (holding that a state statute requiring the Boy Scouts to admit a gay assistant scoutmaster was a violation of the organization's First Amendment rights).

${ }^{297}$ See Robert H. Bork, Neutral Principles and Some First Amendment Problems, 47 IND. L.J. 1, 9 (1971) (questioning the constitutional legitimacy of Griswold). 
neutrality rendered it relatively immune to moral shifts, for it protected traditionalist groups, from the Ku Klux Klan to the Boy Scouts of America. ${ }^{296}$ This neutrality has made the Speech Clause the first resort of whatever identity group is the current object of state (re)education-from homosexuals in the 1950 s and 1960 s, to right-tolifers picketing abortion clinics in the 1980 s and 1990s.

IBSM-related litigation transformed the Due Process Clause in three ways. Procedurally, due process now entails a detailed set of guidelines for criminal arrests and prosecutions, in large part inspired by black people's politics of protection against racist police forces. The rule against excessively vague criminal laws is nothing new, but it has been given deep bite by cases brought against birth control and abortion advocates, gay men, and cross-dressers. Substantively, the right to privacy is largely a creature of the birth control and abortion movements, and its most controversial limiting principle is the Court's announcement that it does not protect gay people from being arrested for engaging in consensual "homosexual sodomy." Judge Bork's denunciation of this line of cases brought upon him an IBSM campaign of vilification that solidified the right of privacy in American constitutional law for the next generation. ${ }^{297}$

Of course, the most significant transformation of American law due to IBSMs has been the creation of the tiered Equal Protection Clause. Between 1900 and 1945, before the period of IBSMs, the Court applied this clause leniently, allowing de jure racial segregation and compulsory sterilization, for example. ${ }^{298}$ The civil rights cases impelled the Court to a non-lenient scrutiny, which it had no option but to concede was a "strict" contrast to the "rational basis" scrutiny of the earlier cases. Once race was established as a suspect classification, the women's, lesbian and gay, and disabled people's movements all sought to establish their defining traits as similarly suspect. Reluctant to create new categories of suspect classifications, but also anxious to strike down some of the statutes that came before them, the Justices have proceeded to create new gradations, "intermediate" scrutiny for sex-based classifications ( Craig) and "rational basis with bite" for those involving disability (Clebume) and, sometimes, sexual orientation (Evans). ${ }^{299}$

${ }^{298}$ See Plessy v. Ferguson, 163 U.S. 537 (1896) (analyzing the Equal Protection Clause leniently and upholding segregation law); Buck v. Bell, 274 U.S. 200 (1927) (rejecting an equal protection claim against a Virginia statute providing for the sterilization of the "feeble-minded").

${ }^{299}$ On the Court's current level of scrutiny, see Toni M. Massaro, Gay Rights, Thick 
Table 3 summarizes, in a more abstract way, the roles different individual rights provisions of the Constitution have been able to play in the ongoing politics of recognition by IBSMs and the counter-politics of preservation by traditionalists.

and Thin, 49 STAN. L. REv. 45 (1996). For different conceptions of the Court's approach, compare the majority opinion in Clebume, 473 U.S. 432, 440-42 (1985), advocating tiered levels of scrutiny, with Justice Stevens' concurrence, 473 U.S. at 451 , viewing levels of scrutiny on a continuum, and with Justice Marshall's dissent, 473 U.S. at 460 , determining the level of scrutiny based on a sliding scale. 
Table 3

The Impact of IBSMs on American Constitutional Law

\begin{tabular}{|c|c|c|c|}
\hline & $\begin{array}{c}\text { Marginalized } \\
\text { Groups Largely } \\
\text { Not Mobilized, } \\
\text { 1930s-1950s } \\
\end{array}$ & $\begin{array}{c}\text { Marginalized } \\
\text { Groups Mobilizing, } \\
\text { 1950s-1970s }\end{array}$ & $\begin{array}{c}\text { Some Marginalized } \\
\text { Groups Assimilated } \\
\text { into Normal } \\
\text { Politics, }>1970 \mathrm{~s} \\
\end{array}$ \\
\hline $\begin{array}{l}\text { Freedom of Speech } \\
\text { Jurisprudence }\end{array}$ & $\begin{array}{l}\text { Anti-Kulturkampf } \\
\text { Idea. State cannot } \\
\text { engage in a cam- } \\
\text { paign to erase or } \\
\text { completely silence } \\
\text { an unpopular mi- } \\
\text { nority (NAACP } \\
\text { cases). }\end{array}$ & $\begin{array}{l}\text { Robust Political } \\
\text { Debate. State must } \\
\text { allow minorities } \\
\text { public space to } \\
\text { object to their } \\
\text { stigmatization. } \\
\text { State cannot pro- } \\
\text { tect traditionalists } \\
\text { against critique } \\
\text { (New York Times v. } \\
\text { Sullivan). }\end{array}$ & $\begin{array}{l}\text { Enclaves of } \\
\text { Intolerance. Court } \\
\text { protects traditional- } \\
\text { ist groups from } \\
\text { anti-discrimination } \\
\text { laws (Dale, Abortion } \\
\text { protest cases). }\end{array}$ \\
\hline $\begin{array}{l}\text { Due Process } \\
\text { Jurisprudence }\end{array}$ & $\begin{array}{l}\text { Procedural Due } \\
\text { Process. Minority is } \\
\text { entitled to the pro- } \\
\text { tections of the rule } \\
\text { of law, especially } \\
\text { procedural ones } \\
\text { (Powell, Homophile } \\
\text { cases of the 1950s). }\end{array}$ & $\begin{array}{l}\text { Substantive Due } \\
\text { Process (Privacy). } \\
\text { The right to privacy } \\
\text { develops to protect } \\
\text { against government } \\
\text { snooping into our } \\
\text { personal lives } \\
\text { (Griswold, Roe, } \\
\text { Hardwick dissents). }\end{array}$ & $\begin{array}{l}\text { Structural Due } \\
\text { Process (Localism). } \\
\text { Traditionalists } \\
\text { press for local } \\
\text { rather than } \\
\text { national regulation } \\
\text { (Federalism cases) } \\
\text { and for parental } \\
\text { control (Casey, } \\
\text { Dale). }\end{array}$ \\
\hline $\begin{array}{l}\text { Equal Protection } \\
\text { Jurisprudence }\end{array}$ & $\begin{array}{l}\text { Rational Basis Scru- } \\
\text { tiny. Traditional } \\
\text { equal protection } \\
\text { accepts regulatory } \\
\text { distinctions so long } \\
\text { as they have some } \\
\text { plausible rationale } \\
\text { (Plessy, Buck } v \text {. Bell, } \\
\text { Early sex discrimi- } \\
\text { nation cases). }\end{array}$ & $\begin{array}{l}\text { Heightened Scrutiny. } \\
\text { Court develops } \\
\text { "strict scrutiny" in } \\
\text { race cases (Loving); } \\
\text { "intermediate } \\
\text { scrutiny" in sex } \\
\text { cases (Craig); } \\
\text { "rational basis with } \\
\text { bite" in disability } \\
\text { (Cleburne) and } \\
\text { sexual orientation } \\
\text { (Evans) cases. }\end{array}$ & $\begin{array}{l}\text { "Reverse Discrimina- } \\
\text { tion." Newly } \\
\text { marginalized } \\
\text { traditionalists argue } \\
\text { that minority is } \\
\text { being given "special } \\
\text { rights" that violate } \\
\text { equality norms } \\
\text { (Evans dissent, Ada- } \\
\text { rand). }\end{array}$ \\
\hline
\end{tabular}




\section{Normative Inquiry: Justification(s) for the Supreme Court's Response to IBSMs?}

The normative assumption of Table 3 and throughout this Article is pluralism: the polity consists of numerous and often competing groups, including not just economic groups but also social groups; the goal of politics is moderation and accommodation of the interests of as many salient groups as possible, without disturbing the ability of the state and the community to press forward with collective projects. ${ }^{300}$ In a pluralist system, the role of the judiciary is not to ensure the triumph of any particular group or norm, but is instead to assure that all groups pursue their interests and normative goals through the regular organs for change and debate. Under pluralist assumptions, it is not objectionable, per se, that a trait is disapproved and a minority considered subordinate. What is problematic is that social and political resources may be deployed for wasteful conflicts among groups. Consider the implications of this model for the role of the judiciary at each stage in an IBSM's potential life cycle.

So long as the minority is socially despised and not organized, it will be subject to pervasive state as well as social discrimination, and judges will do no more than trim back excessive or unusual state discrimination. Many nascent social movements will be extinguished by state Kulturkampfs, as the polygamy movement among Mormons was at the end of the nineteenth century, without the slightest objection from the Supreme Court. ${ }^{301}$ Under pluralist assumptions, the Ameri-

${ }^{300}$ These features of pluralism are articulated and defended in ROBERT A. DAHL, Pluralist DemoCRACY IN THE United States: CONFliCT AND CONSENT 24 (1967); THEODORE LowI, THE END OF Liberalism 51 (2d ed: 1979); and Nicholas Miller, Pluralism and Social Choice, 77 AM. POL. SCI. REv. 734, 734 (1983).

${ }^{301}$ See Late Corp. of the Church of Jesus Christ of Latter Day Saints v. United States, 136 U.S. 1, 50 (1890) (allowing confiscation of Mormon Church property); Davis v. Beason, 133 U.S. 333, 344-46 (1890) (establishing that polygamists can be denied the right to vote); Reynolds v. United States, 98 U.S. 145, 161-67 (1878) (finding that religiously motivated bigamy constitutes a crime).

${ }^{302}$ See Gibson v. Fla. Legislative Investigating Comm., 372 U.S. 539 (1963) (invalidating Florida's effort to obtain NAACP's membership records); NAACP v. Alabama $e x$ rel. Patterson, 357 U.S. 449 (1958) (holding similarly for Alabama). 
can judiciary cannot stop a nationwide Kulturkampf the populace supports, but judges can thwart local and state campaigns and slow down national ones. Thus, the Supreme Court was able to thwart southern state campaigns to destroy the NAACP in the $1950 \mathrm{~s},{ }^{302}$ and state courts were able to do the same for police campaigns to terrorize gay people after World War II. ${ }^{303}$ Although a judiciary that defies a national $\mathrm{Kul}$ turkampf risks institutional suicide, one that cheers it on risks alienation of minority groups from the system of governance and angry retaliation at a future date.

The same pluralist premises are attentive to the possibility that today's outlaw minority will be tomorrow's social movement. If the minority survives the Kulturkampf and is able to organize effectively in its defense, there will be a shift from a segregation regime toward public tolerance of the minority. The challenge for the state in this transition is to accommodate the minority and to encourage it to work within the pluralist system, but without alienating traditionalists alarmed by the new status of a group they still fear or despise. The role of constitutional law in this legal-political shift of regimes is threefold. The Speech and Press Clauses assure minority groups that the state will protect their ability to educate and organize, so long as they do so within the rules the state lays down. Thus, judges stood ready to protect the ability of Planned Parenthood, the NAACP, and the Mattachine Societies to educate the community and petition the government. The Equal Protection and Due Process Clauses provide a mechanism for judges to edit the least defensible discriminations from operative law and sometimes to reverse the burden of political inertia, to require the system to revisit outdated discriminations. Brown, Roe, and the sex discrimination cases after the ERA were the most dramatic burden-shifting decisions. If a countermovement forms, the courts will mediate the culture clash between it and the social movement. Courts will tolerate symbolic reaffirmations of traditionalist values but will discourage both sides from using the state to gain an unfair advantage against the other. Thus the judiciary went along with state policies against unduly "promoting" abortion, ${ }^{304}$ homosexuality, ${ }^{305}$ and

${ }^{303}$ See ESKRIDGE, GAYLAW, supra note 14, at 84-86, $94-95$ (surveying protective decisions by judges in California, the District of Columbia, and New York during anti-homosexual Kulturkampf of 1946-1957).

sot See Harris v. McRae, 448 U.S. 297, 315-18 (1980) (upholding federal refusal to fund nontherapeutic abortions as part of Medicaid for the poor); Maher v. Roe, 432 U.S. 464, 479-80 (1977) (upholding state refusal).

${ }^{305}$ See Boy Scouts of Am. v. Dale, 530 U.S. 640, 653 (2000) (protecting the Boy Scouts against the possibility that the public would view the organization as encourag- 
racial integration ${ }^{3(k i)}$ once the pro-life, traditional family values, and

ing homosexuality if it had gay scoutmasters).

${ }^{3}$ See Milliken v. Bradley, 418 U.S. 717, 752 (1974) (finding that a federal court may not impose a multidistrict, area-wide remedy for single-district school segregation violations), discussed in JOHN C. JiFFrIES, JR., JUSTICE LEWIS F. POWELL., JR. 286 (1994) (suggesting that the Burger Court was reluctant to require school integration when whites flee to suburbs); Freeman v. Pitts, 503 U.S. 467, 490 (1992) (illustrating the Court's more aggressive stance in the direction of local choice and away from state promotion of integration).

${ }^{307}$ Thus the Supreme Court struck down miscegenation laws that had been abandoned everywhere outside the South, see Loving v. Virginia, 388 U.S. 1 (1967); contraception laws repealed everywhere except Connecticut, see Griswold v. Connecticut, 381 U.S. 479 (1965), and Massachusetts, see Eisenstadt v. Baird, 405 U.S. 438 (1972); and a local zoning law having no statewide analogues, see City of Cleburne v. Cleburne Living Ctr., 473 U.S. 432 (1985). Contrast these cases with Bowers v. Hardwick, 478 U.S. 186 (1986), where the Court upheld a consensual sodomy law like those then in effect in twenty-four other states and the District of Columbia.

Compare ANTONIN SCALIA, A MATTER OF INTERPRETATION: FEDERAL COURTS AND THE LAW (1997) (advocating text-based originalism), with Owen Fiss, The Supreme Courl, 1978 Term-Foreword: The Forms of Justice, 93 HARv. L. REv. 1, 14 (1979) (utilizing justice-based public values in constitutional interpretation).

THE: Federal.sST No. 78, at 465 (Alexander Hamilton) (Clinton Rossiter ed., 1961). Hamilton defended judicial independence so that the Court could protect the will of the people and mitigate the ills of "unjust and partial laws." Id. at 470. Hamilton observed that the courts would act contrary to "the will of the legislature" sometimes, "but they can never be so extensive as to amount to an inconvenience, or in any sensible degree to affect the order of the political system." THE FEDERALIST NO. 81, at 48485 (Alexander Hamilton) (Clinton Rossiter ed., 1961). There were other checks to assure that judges would not grab power under the guise of either statutory or constitutional constructions: "the general nature of the judicial power" and "the manner in which it is exercised"; the "comparative weakness" of the judiciary vis-à-vis the political branches; and the possibility of impeachment, which "is alone a complete security." Id. at 485 .

${ }^{810}$ This is the famous-and controversial-argument of ELY, supra note 291. Although assailed from all quarters, Ely's theory remains for many the most persuasive theory of judicial review.

${ }^{311}$ Marbuty \%. Madison, 5 U.S. (1 Cranch) 137 (1803) (announcing the Court's power of judicial review), perfectly fits the model, as Chief Justice Marshall (an important federalist at the Virginia ratifying convention) avoided conflict with the President and Congress by strategic choices not supported by standard legal criteria. See William VanAlstyne, A Critical Guide to Marbury v. Madison, 1969 DukE L.J. 1 (providing a critical in-depth analysis of the opinion in its context). For other examples, see Cohens $v$. Virginia, 19 U.S. (6 Wheat.) 264, (1821), invalidating more forthrightly a wayward state law, but strategically narrowing a federal lottery law to the result Marshall wanted; and McCullough v. Maryland, 17 U.S. 316, 432-35 (1819), striking down parochial state law and setting forth an early version of a representation-reinforcing justification for aggressive judicial review.

${ }_{312}$ This argument is elaborately presented in ESKRIDGE, supra note 198, at chs. 4-5. 
states' rights movements had proven their political potency.

The gay rights and pro-choice movements are currently stuck in the tolerance zone, but the social movements seeking rights for people of color, women, and many of the disabled have for the most part moved to the next level-normal politics. Having persuaded the community that their trait variations ought to be deemed benign for most if not all purposes, these movements have become part of the pluralist system. At this point, constitutional protections become clean-up operations, removing outlier discriminations and fine-tuning the terms of clashing group interests. Examples of constitutional housecleaning include Loving, Griswold, and perhaps Clebume. Each was a landmark constitutional decision-but one not handed down until after civil rights, birth control, and disability rights groups had won nationwide recognition of their equality rights. ${ }^{307}$ Once a minority group has become a part of normal politics, the judiciary will generally enforce remedial laws with enthusiasm, occasionally protecting traditionalists against undue invasions of their liberties. Table la summarizes the pluralism-inspired regime I have just described. 
Table 1a

Legal Regimes and Judicial Role in the Life Cycle of an IBSM

\begin{tabular}{|c|c|c|c|}
\hline & $\begin{array}{l}\text { Marginalized } \\
\text { Group } \\
\text { That Has Not } \\
\text { Mobilized } \\
\text { (Malign Varia- } \\
\text { tion) } \\
\end{array}$ & $\begin{array}{c}\text { Marginalized } \\
\text { Group Mobilizes } \\
\text { (Tolerable Varia- } \\
\text { tion) }\end{array}$ & $\begin{array}{l}\text { Marginalized } \\
\text { Group } \\
\text { Assimilated } \\
\text { into Politics } \\
\text { (Benign Varia- } \\
\text { tion) } \\
\end{array}$ \\
\hline $\begin{array}{c}\text { Traditionalist } \\
\text { Citizens Are } \\
\text { Not Fearful }\end{array}$ & $\begin{array}{l}\text { [1] Apartheid Re- } \\
\text { gime. Laws dis- } \\
\text { criminating } \\
\text { against } \\
\text { minority and } \\
\text { segregating it } \\
\text { from the norm. } \\
\text { Judiciary acqui- } \\
\text { esces (Plessy), but } \\
\text { insists that rule } \\
\text { of law applies } \\
\text { (Cases enforcing } \\
\text { separate but } \\
\text { equal). }\end{array}$ & $\begin{array}{l}\text { [3] Tolerance Re- } \\
\text { gime. Courts } \\
\text { assure minority } \\
\text { rights to } \\
\text { protest and } \\
\text { organize } \\
\text { (NAACP cases). } \\
\text { Minority gains } \\
\text { legislative repeal } \\
\text { or judicial invali- } \\
\text { dation of state } \\
\text { discriminations } \\
\text { (Broun). } \\
\text { Legislation pro- } \\
\text { hibiting private } \\
\text { discrimination } \\
\text { (super-statutes). }\end{array}$ & $\begin{array}{l}\text { [5] Pluralist Re- } \\
\text { gime. Anti- } \\
\text { discrimination } \\
\text { super-statutes } \\
\text { vigorously } \\
\text { enforced. State } \\
\text { subsidies or rules } \\
\text { helping the } \\
\text { minority. Courts } \\
\text { clean up outlier } \\
\text { discriminations } \\
\text { (Loving, Griswold, } \\
\text { Cleburne, Evans). }\end{array}$ \\
\hline $\begin{array}{l}\text { Traditionalist } \\
\text { Citizens } \\
\text { Are Fearful }\end{array}$ & $\begin{array}{l}\text { [2] Terror Regime. } \\
\text { Kulturkampfs } \\
\text { seeking to sup- } \\
\text { press the minor- } \\
\text { ity may be slowed } \\
\text { down by courts. } \\
\text { Courts ought to } \\
\text { intervene to pre- } \\
\text { vent the state } \\
\text { from being a tool } \\
\text { of private venge- } \\
\text { ance against mi- } \\
\text { nority (Powell). }\end{array}$ & $\begin{array}{l}\text { [4] No Promo Re- } \\
\text { gime. Equality } \\
\text { moves more } \\
\text { slowly and bows } \\
\text { to arguments } \\
\text { that the state not } \\
\text { promote nontra- } \\
\text { ditional conduct } \\
\text { (Abortion fund- } \\
\text { ing cases, Hard- } \\
\text { wick). Localism } \\
\text { concerns (deseg- } \\
\text { regation cases). } \\
\text { Exemptions from } \\
\text { anti- } \\
\text { discrimination } \\
\text { laws (Dale). }\end{array}$ & $\begin{array}{l}\text { [6] Guerilla Re- } \\
\text { gime. Tradition- } \\
\text { alists' ongoing } \\
\text { war against mi- } \\
\text { nority becomes } \\
\text { illegal in part. } \\
\text { Still, courts as- } \\
\text { sure space for } \\
\text { traditionalists } \\
\text { (KKK cases, Op- } \\
\text { eration Rescue } \\
\text { cases). }\end{array}$ \\
\hline
\end{tabular}


There are three ways one might criticize the judiciary's performance under the regime described by Table la.

\section{Should the Court Consider the Effect of Its Decisions on the Operation of Pluralist Politics?}

Perhaps the most fundamental criticism is that the foregoing pluralist model misconceives the role of the Supreme Court under a proper understanding of the Constitution. The role of the Court, these critics would maintain, is to declare the nation's public law by interpreting the great mandates of the Constitution. Decisions like Brown are great and correct, not because they nudged along the political system toward integrating minorities (however laudable a goal that might be), but because they correctly deduced the meaning of the Constitution as applied to widespread legal practices and boldly announced precisely the meaning so derived, without flinching. Some of these critics believe the Court should follow text-based or originalist modes of reasoning; others believe the Court should reason from the justice-based purposes and principles of the great constitutional provisions. ${ }^{308}$ But they all resist a philosophy whereby the Court behaves strategically and the constitutional rule might change with public opinion. That the Supreme Court does act in this way, as an institution, is no justification for how it ought to act.

For starters, one can debate what approach to constitutional interpretation best reflects the Constitution's vesting the "judicial Power" in the Supreme Court and inferior federal courts. It is far from obvious that Article III requires or even authorizes the federal judiciary to do nothing more than apply standard rule of law or justice criteria to constitutional issues. Any theory of constitutional interpretation insisting that the Court plays no role in the proper operation of the democratic process and ought to ignore the reactions of the body politic to its decisions must respond to arguments such as these: (1) The federalists, defending Article III, assured the states that the Court was the "least dangerous branch" that would not defy the political process over long stretches of time. ${ }^{30 !}$ (2) The structure of the Constitution is proceduralist, as are most of the individual rights, suggesting that the primary role of courts in judicial review is to referee the political process, neither dictating substantive results nor avoiding entanglement. ${ }^{310}$ (3) The early history of judicial review reveals that judges as well as the founders expected the Court to defer to the political process for the most part, but to intervene strategically when the process was operating too hastily or in a biased way. ${ }^{311}$ These are pro- 
visional arguments only.

In my view, no one can establish to a reasonable certainty that the Constitution requires a particular substantive theory of judicial review and that it forbids the Court from engaging in strategic behavior. In that event, one must defend a non-strategic approach to judicial review from the perspective of abstract theory. For example, one might say that the rule of law or the sense of shared justice unravels if the Court is not unbending in its discernment and application. One might say that, but no one has ever demonstrated it to be true in fact, and there is every reason to believe that abstract rule of law or justice theories cannot exclude a pragmatic element. If the Court cannot enforce its judgments because the political process refuses to back up the Justices, then the abstract value of the rule of law evaporates and abstract justice becomes concrete chaos or injustice. Once abstract theory concedes that the Court must at least move cautiously, and perhaps implement controversial interpretations incrementally rather than immediately (precisely the strategy in Brown II), that theory must account for the operation of the pluralist process. ${ }^{9.2}$

A final question is this: What is the Supreme Court's comparative advantage? A lot of lawyers say it is applying texts to concrete cases, an idea that academics have discredited in the hard cases. Academics generally think the Court, because of its independence and life tenure, operates best as a source of justice, but the Court's performance in this arena has been unimpressive as well. Ely maintains that the Supreme Court is best situated to be a process-oriented referee. This remains an open, much-debated question. On the one hand, the Supreme Court has often intervened in a productive way. Although Gerald Rosenberg seems right to say that actual integration did not come to the South until the President and Congress got involved, Michael Klarman seems equally right to respond that Brown advanced the matter on the national agenda, even if indirectly. ${ }^{313}$ Aside from the critical role Brown played in resolving the Montgomery bus boycott, it helped solve the free rider problem with collective action by turning the civil rights struggle into an, assurance game, as discussed above. Other examples of this point are cases like Griswold and Loving, where the Court cleaned up normatively obsolescent state laws

${ }^{313}$ Compare ROSENBERG, supra note 107, at 49-54 (utilizing statistical data to measure the contribution of the courts vis-à-vis Congress and the executive branch in desegregating public schools), with Klarman, supra note 107, at 85 ("Brown was indirectly responsible for the landmark civil rights legislation of the mid-1960s by catalyzing southern resistance to racial change."). 
whose repeal was thwarted by local politics, and the dozens of due process and freedom of speech cases where the Court insisted on the rights of lesbians and gay men, people of color, and women to their own private spaces and to publish unpopular ideas, to march and protest, and to form associations to change public law and social norms.

On the other hand, there are cases where the Court blundered. How common are these blunders? They call into question the Court's skill in considering strategic politics. Are the blunders correctable? That is, are they the result of the Court's excessive caution, which leaves the political process no worse off and able to be corrected later on? How often are they the result of the Court's excessive meddling, which leaves the political process worse off?

\section{Is the Court Too Passive a Player in Pluralist Politics?}

Another kind of criticism, therefore, would operate from within the pluralist model's assumptions: such and such decision undermined the goals of pluralism. Because there are so many interlinked variables, it is hard to tell exactly what effects any Supreme Court decision has had on the operation of American politics; because of the counterfactual nature of the inquiry, it is impossible to figure out what would have happened if the Court had taken a different path. Nonetheless, educated guesses can be essayed, and one can intelligently believe that the Supreme Court has miscalculated the political consequences of its decisions in some important IBSM cases.

Within the assumptions of pluralism, the Court has sometimes been too reluctant to slow down state campaigns that impose extraordinary burdens on minorities who are not hurting other people. The political equilibrium of the era might have prevented the Court from barring states from sterilizing people with mental disabilities in Buck $v$. Bell, for example, but the Court could certainly have required extra procedures before the state could sterilize such a person-or could have required a better factual record showing harm to the body politic before allowing the legislature to impose such a penalty. Similarly, in Korematsu, the Court should have held federal incarceration of innocent Japanese-American citizens to higher procedural scrutiny at the very least. I believe this is the best criticism of the Court.

Many have criticized Hardwick and Dale as judicial acquiescence in antigay prejudice, and Hardwick was certainly a blunder under the pluralist mociel. But Dale fits the model quite well and is narrowly (or confusingly) enough written to leave enough space for antidiscrimination laws to operate against employers and traditional pub- 
lic accommodations such as hotels and restaurants. ${ }^{314}$ The Court in Evans distanced itself from Hardwick, and the faster it fades as a precedent the better; unfortunately, it still serves as cover for lower court judges who acquiesce in state policies that penalize gay people more concretely than Georgia's little-enforced consensual sodomy law. ${ }^{315}$ While gay people, such as I, do not appreciate the perseverance of Hardwick as the law of the land, its damage is ameliorated by the aggressive review of sodomy laws by state courts under state constitutions. ${ }^{316}$ For thoughtful critics of the Supreme Court's decision, it is not clear how harmful an error Hardwick was.

Likewise, one might criticize the Supreme Court for moving too slowly in scrutinizing race- and sex-based classifications. The Court moved deliberately, which left many such classifications in place for years, but its pace had advantages for these social movements: little victories attracted new members to the social movement, both because there was tangible evidence that success was forthcoming and because there remained formal exclusions that people were eager to challenge. In my view, the better criticism of the Court is that it has been

\$14 I am amazed that the New Jersey courts construed their law to situate the Boy Scouts as a "public accommodation," and I have counseled against this kind of construction in William N. Eskridge, Jr., A Jurisprudence of "Coming Out": Religion, Homosexuality, and Collisions of Liberty and Equality in American Public Law, 106 YALE L.J. 2411 (1997).

${ }^{315}$ See, e.g., Shahar v. Bowers, 114 F.3d 1097 (11th Cir. 1997) (en banc) (holding that a state employer's revocation of plaintiff's employment offer because of her purported same-sex marriage did not violate plaintiff's constitutional rights).

${ }^{316}$ Since Hardwick, state sodomy laws have been authoritatively invalidated in Georgia (the Hardwick law!), Kentucky, Montana, and Tennessee. See ESKRIDGE \& HUNTER, supra note 251, at 54-55 (discussing state grounds for sodomy law challenges); id. at 7-9 (Supp. 2001). As of September 2001, lower courts have invalidated the laws in Arkansas, Maryland, and Minnesota. See id. State constitutional challenges have lost in Kansas, Louisiana, and Missouri. See id. They are pending in Massachusetts and Texas. See id. at 8-22.

:17 442 U.S. 256, 271 (1979) (holding that Massachusetts did not discriminate against women in violation of the Equal Protection Clause by granting absolute lifetime employment preference to veterans).

sit See, e.g., MARY ANN Glendon, AbORTION AND DIVORCE IN WESTERN I_AW: AMERICAN FAILURES, EuROPEAN CHALLENGES (1987) (discussing how European countries, through legislative reform without judicial pressure, have achieved about the same abortion regime as the United States, after 30 years of judicial review); ROSENBERG, supra note 107, at 185-201 (arguing that Roe had little effect on public opinion and helped galvanize private as well as public opposition to abortion on demand). 
too acquiescent in state policies that indirectly harm women and racial minorities and has not required the legislature to present better justifications for such policies. For example, the state's strong veterans' preference for civil service positions litigated in Personnel Administrator $\%$. Feeney ${ }^{317}$ had a ridiculously discriminatory effect against women, who were largely excluded from the military and therefore from the preference. The state's reasons were largely symbolic and hortatory, and ought not to have passed muster given the strength of the preference. Some of the policies (no one knows how many) having adverse effects on women and racial minorities have been changed as a result of legislative or agency attention as well as Title VII litigation.

\section{Has the Court Been Too Aggressive a Player in Pluralist Politics?}

The most serious criticism of the Court would be that it has meddled so much in the political process as to have "corrupted" it. For example, a standard critique of Roe $v$. Wade is that it was not only countermajoritarian, but that it preempted the normal operation of politics, which was in the process of reforming or repealing abortion laws state by state. ${ }^{318}$ The Court may have performed a service by reversing the burden of inertia: before $R o e$, pro-choice women had the tough battle, unwinnable in most states, of pressing reform or repeal legislation through two chambers of the state legislature and obtaining the governor's signature. Roe therefore corrected a political dysfunction (albeit one whose pervasiveness might be questioned, as many states reformed their laws beforehand), but at the cost of hardwiring the political process against pro-life people: after $R o$, they could not persuade any legislature to reinstate old abortion bars. In my view, the pluralist model would have preferred that the Court have invalidated the Texas abortion law in Roe on grounds of due process obsolescence: the law was adopted, before women had the right to vote, to solve problems that medical technology subsequently solved; therefore, the statutory bar to all abortions no longer fit its rationale, and it essentially should have been remanded to the legislature. ${ }^{319}$ In subsequent cases, the Court could then have developed a nuanced equal protection and due process (privacy) approach to sorting out

919 This was the approach taken by Abele v. Markle, 342 F. Supp. 800, 805 (D. Conn. 1972) (Newman, J., concurring), invalidating a Connecticut abortion statute because its original legislative purpose, protecting women's health, was no longer rationally related, discussed in GuIDO CALABRESI, A COMMON LAW FOR THE AGE OF STATUTES 27-29 (1982). 
statutes that still placed too great a burden on women's reproductive freedom, basically the approach the Court adopted after twenty years of hand-wringing over Roe. ${ }^{320}$

Roe illustrates the central problem with a philosophy that rejects pragmatic considerations in constitutional jurisprudence: it doesn't protect rights or the rule of law. If a woman truly has a constitutional right to choose abortion on demand (under the "proper" theory of constitutional interpretation), but the Court announces it in a politically insensitive way, the Court can undermine the right by stimulating extra opposition to it. Before Roe, increasing numbers of Americans were changing their-minds about abortion, the large majority concluding that it is sometimes permissible, and many concluding that it should always be the mother's choice. The debate was focused on the issue and the stories of women like Sherri Finkbine. After Roe, the debate's focus became diffused, in (large) part because pro-life people articulated stories of aborted human beings and in part because people objected that the issue had been taken away from the democratic process. This hard-to-determine legitimacy factor was a price of Roe. I do not agree, however, that Roe is responsible for the pro-life countermovement. The descriptive model of IBSMs in this Article suggests that any substantial success on the part of the pro-choice movement would have triggered a strong countermovement, for it would have altered important status entitlements and gender roles. The pro-life countermovement was already well under way by the time Roe was handed down; it did pick up steam after Roe, in part because the decision's abrogation of all abortion laws was a nationwide shift in gender role and status. ${ }^{321}$

Apart from Roe, it is remarkable how few Supreme Court decisions involving identity-based status and conduct have been widely or persuasively criticized as too aggressive. My candidate for next-mostactivist blunder is Adarand and the other affirmative action cases, but the damage done by those cases is not large yet. ${ }^{322}$ Decisions as activist

320 See Planned Parenthood v. Casey, 505 U.S. 833, 878-79 (1992) (joint opinion announcing the judgment of the Court) (reaffirming the essential holding of Roe, but rejecting the trimester framework in favor of undue burden analysis).

${ }^{321}$ Compare LUKER, supra note 13, at 133-37 (describing the emergence of the rightto-life movement in California right after abortion reform law was adopted in 1967), with id. at 137-45 (discussing the influx of many more pro-life commitments after Roe).

:322 Adarand is hard to defend on rule of law grounds, because it is judicial activism unsupported by constitutional text, original expectations, or precedent. As an application of judicialized social policy (race cannot be a criterion), the opinions are intellectually weak and empirically defenseless at the present time. By disrupting the opera- 
(and hard to defend solely by reference to standard legal criteria) as Brown, Loving, Griswold, Cleburne, Evans, Craig, and NAACP have been praised from a variety of perspectives and criticized mainly for not going far enough. Because academics are likely to underappreciate practical considerations and are politically to the left, this is some evidence that the Court is not being too aggressive and that Roe stands alone as a blunder (with of course great debate over how much of a blunder, if any).

In sum, the normative question, What role should the Court play in the evolution of IBSMs?, remains open to debate. There are no certain answers at this point, but my hypotheses are the following:

The Court ought to provide procedural protections to all minorities, however despised, and ought to impose caution onto law enforcement when the political system is engaged in a Kulturkampf against a minority. (Quadrants 1 and 2 of Table 3.)

Once a minority starts to mobilize as a social movement, the Court ought to protect the minority group's expression and association from state interference and ought to strike down the most serious state penalties against the group. (Quadrants 3 and 4.)

If a minority becomes part of the normal political process, the Court ought to support legislative efforts at remediation and apply super-statutes vigorously, but also ought to protect minoritized traditionalists from losing their own social spaces. (Quadrants 5 and 6.)

\section{CONCLUSION: WHAT NEXT FOR IDENTITY-BASED SOCIAL MOVEMENTS AND THE LAW?}

The IBSMs discussed in this Article flourished as social movements and transformed American public law in the latter half of the twentieth century. At the dawn of the new millennium, the developments described here will continue: gay rights and disability rights movements will continue to press for revocation of de jure state discriminations against their members; culture clashes will remain prominent between those who are pro-choice and pro-life, pro-gay and pro-traditional family values, pro- and anti-affirmative action, and constitutional law will continue to be a situs for these clashes; identity groups and their counter-groups will contend with one another about how aggressively anti-discrimination super-statutes should be applied. These sociopolitical struggles will continue to affect public law and

tion of normal politics, and some degree of remedial justice, decisions like this might do harm. How much harm is impossible for me to tell. 
drive its evolution into new directions. We may also be certain, however, that the social movement patterns we saw in the late twentieth century will be overtaken by new patterns, but we cannot be certain what those patterns will be. I have a few speculations about the new patterns, and their ramifications for American constitutional law.

1. Shift from Stigmatizing Traits to Stigmatizing Conduct. I speculate that over the long term there will be a gradual withering of the traditional totalizing traits, namely, race, ethnicity, disability, and sexual orientation. Just as those traits replaced religion and class as normatively charged characteristics in the twentieth century, so they will erode as prominent legal and even social categories in the twenty-first, for three different reasons. First, even as prejudice continues, the state will continue the process of abandoning discriminations and exclusions that have proven to be nonfunctional and, in some cases, vicious. State rules classifying on the basis of race, ethnicity, sex, sexual orientation, and most disabilities now bear a burden of suspicion that few can withstand. Second, although for the foreseeable future the state will continue to adopt anti-discrimination laws as well, the longer term will see a falling off of minorities' enthusiasm for them. Minorities are already ambivalent about the prominence of their defining trait in identity politics, ${ }^{323}$ and that ambivalence will only grow as a third factor comes into play: the categories themselves will blur, as different racial groups intermarry, as technology allows more disabled people to function well in the world, and as bisexuals, cross-dressers, intersexuals, and other gender-benders become more prominent in public culture. If the human race is still viable in 2101 , race, sex, disability, and sexual orientation will be like religion in 2001-once a focus of hysterical concern, but domesticated as a situs of considerable benign variation among individuals.

What will take the place of these traditional categories? In my view, stigmatizing discourse and legal regulation will shift from traits to conduct. This has already been a theme of identity politics. Traditionalist opponents of rights for women seeking abortions and for gay people have long focused on conduct rather than trait: it is the (bad) acts of abortion and sodomy that the state should disapprove, not

\footnotetext{
${ }^{323}$ For example, some lesbians and gay men not only oppose state rules discriminating against them on the basis of their sex or sexual orientation, but are also skeptical of state rules protecting them against sexual orientation discrimination. Although the two kinds of rules are obviously different, they are similar in retaining sex and sexual orientation as significant state classifications.
} 
women or gay people generally. ${ }^{324}$ What we shall probably see in this century is the erosion of state regulations differentiating people solely on the basis of a trait (race, sex, sexual orientation, most disabilities) and the perseverance of state regulations differentiating on the basis of conduct (sexual activities in particular). Because we are forming a public consensus that explicit trait-based differentiation is unacceptable de jure discrimination, political contests will focus on minority arguments that conduct-based regulations place unfair burdens on its members and constitute unacceptable de facto discrimination. ${ }^{325}$

2. Regulatory Focus on the Health of the Body (Politic) and New Forms of Identity Politics. I do not expect trait-based discrimination to disappear, however. Such discrimination will persevere, but its focal locations will shift away from race, sex, disability, and sexual orientation per se and in the direction of categories that relate to the integrity and health of the body politic. ${ }^{326}$ As the world gets smaller and more dangerous for us Americans, the country's old obsession with immigration exclusions and regulations, which abated after the 1950 s, will return, perhaps with a vengeance. Security fears combined with a renewed nationalism will yield new and unpredictable immigration and naturalization regulations. Because those regulations will have raceand ethnicity-based effects, the old categories will persevere, but in the new form suggested above: the barricaded state of the twenty-first century will deny that its security measures involve race- or ethnicitybased profiling or exclusions, but certain (and perhaps shifting) racial and ethnic minorities will claim that this is the (intended) effect of facially neutral state rules and of unexplained state practices.

A different kind of body politic concern will preserve sexual orientation and sex as categories of closeted relevance, for they will map

${ }^{924}$ To be sure, the role of the disapproved conduct differs in the two cases in text. For traditionalists, the trait of homosexuality is repeatedly confused with homosexual conduct, whereas opposition to abortion does not confuse gender with the disapproved act.

${ }^{325}$ Examples of the debates described in the text are pro-choice arguments that abortion availability is necessary for women's equality; arguments by people of color that certain laws (such as the penalty disparity between crack and powdered cocaine) have dramatic racially discriminatory consequences; arguments by some ethnic and racial minorities (especially Latinos) that language and accent discrimination bears unfairly on them; and arguments by people with physical disabilities that lack of accommodations prevents them from participating in the workplace and other forums.

${ }^{326}$ As before, this is not an entirely new theme. The eugenics movement and various antigay campaigns in the last century emphasized the dangers that certain people, like sex workers, the disabled, gay people, and degenerates of all sorts, posed to the body politic. 
onto state concerns about disease and contagion. Just as the body politic is threatened by new foreign enemies, so can it be weakened by new foreign diseases. Gay men and women have long been stigmatized as carriers of disease. Subgroups will no doubt find themselves objects of Trojan Horse fears, and that scrutiny will bestir some of them toward new kinds of social movements. As for disability, its new name will be the eugenics flowing from the genome project. Once the state can predict the consequences of procreation, there will be pressures for rules and regulations, which will in turn beget new identity movements.

3. Changing Role of the State: From Persecutor to Normalizing ProblemSolver. AIDS activism is one face of identity politics in the new century. It is animated by a group defined by a disease that resists that definition at the same time it seeks more state funding and programs. Its members cut across traditional lines but are dominated by the poor, people of color (especially blacks and latinos), drug addicts, (decreasingly) gay and bisexual men, and (increasingly) women, especially women of color. AIDS activism suggests a final speculation about identity politics in the new millennium: the changing role of state as regulator, as the state sustains or increases its role as a potential problem-solver. Recall the list of state discriminations on the basis of race, ethnicity, sex, sexual orientation, and disability (circa 1945) which was the lead-in to Part I of this Article. All of the identity groups coming together between 1945 and 1975 were driven by the civil rights model, with variations. The civil rights model, encapsulated in the various diagrams and tables in this Article, will be imperfectly applicable to the IBSMs forming after 1975. By and large, such IBSMs will not be inspired by de jure or vicious de facto state discrimination against their members, for such laws have been declawed or threatened by the civil rights era. So many or most of the new IBSMs will accuse the state of discriminatory neglect rather than discriminatory aggression and will be seeking state subsidies and other interventions. One challenge faced by these IBSMs will be to solve collective action problems through private mobilization (such as the Internet) and to enlist the state immediately as an ambivalent ally.

A larger challenge faced by these IBSMs is that state subsidies usually come with strings attached. Thus, an IBSM seeking affirmative state assistance not only invites a political debate over whether or how much such assistance is justified but also introduces new debates about the conditions that should be attached to the assistance. The subsidizing or facilitating state, moreover, will still be a highly regula- 
tory state. The mode for regulating nonconformity will shift away from a persecutorial model that regulates by disapproving and penalizing and toward a conditional subsidy model that regulates by selectively approving and subsidizing. This shift in state policy toward minorities presents new challenges to constitutional doctrine as well as public policy in this new century. 
